\title{
UNA REVALUACIÓNY APROXIMACIONES A LA INTERPRETACIÓN DEL CALENDARIO MÍTICO CEREMONIAL MOCHE BASADO EN LA ICONOGRAFÍA DE LOS TEMAS COMPLEJOS DE LA HUACA CAO VIEJO, COMPLEJO EL BRUJO, COSTA NORTE DEL PERÚ
}

\author{
RÉGULO FRANCO JORDÁN \\ Fundación Augusto N. Wiese. | Director Proyecto Arqueológico El Brujo-Museo Cao. \\ rfranco@fundacionwiese.com | regulofrancoj@gmail.com
}

\section{RESUMEN}

Los Temas Complejos corresponden a representaciones de barro polícromos, ubicado en dos templos prehispánicos de la cultura Moche de la costa norte del Perú, pertenecientes al siglo VII d.C. aproximadamente. Es una de las extraordinarias expresiones simbólicas y artísticas que se ha dado a conocer en el siglo XX. Esta composición iconográfica es resultado de cambios ideológicos fuertes que ocurrieron al interior de la sociedad Moche en respuesta a una crisis climática que motivó la restauración de un nuevo orden frente al caos y la instauración de un calendario mítico-ceremonial representado en los dos muros con Temas Complejos. Este artículo enfoca el estudio iconográfico y el uso de fuentes etnohistóricas para aproximarnos a su significado.

Palabras Claves: Temas Complejos, iconografía, calendario ceremonial.

\section{ABSTRACT}

The complex themes belong to a polychrome relief made from mud located in two pre-Hispanic temples that belong to Moche Culture in the northern coast of Peru dated circa VII century AD. This is an extraordinary symbolic and artistic representation found in the last XX century. This iconographic composition is the result of the strong change of attitude within the Moche society as an answer to the climate crisis. This new attitude implied the instauration of a new order to confront the chaos and the installation of a new mythical-ceremonial calendar represented in these two murals with complex themes. This article focuses on an iconographic study and on the use of etnohistorical sources to approach its importance.

Keywords: Complex Themes, iconographic, ceremonial calendar. 


\section{INTRODUCCIÓN}

Este artículo corresponde al estudio de dos muros con iconografía compleja descubierto en la Huaca Cao Viejo en el Complejo Arqueológico El Brujo, ubicado a $60 \mathrm{~km}$ al noroeste de la ciudad de Trujillo, en la región de La Libertad, Perú, y a 4 km de distancia del pueblo histórico de Magdalena de Cao (figs.1-3). Su hallazgo se dio a partir del inicio de un proyecto de investigaciones arqueológicas y conservación conducidas por la Fundación Wiese en convenio con la Universidad Nacional de Trujillo y el Instituto Nacional de Cultura (ahora Ministerio de Cultura).

Estos murales polícromos en alto relieve encontrados en 1990 fueron denominados "Temas Complejos" porque tienen en su composición muchas representaciones recargadas dentro de estilo barroco, cuya significación general, a pesar de las aproximaciones, tiene todavía muchos enigmas por resolver.

En efecto, la propuesta de interpretación de los Temas Complejos, se basa en un análisis anterior preiconográfico de temas y escenas que se vinculan con una estructura narrativa que nos permite deducir, en ambos casos, la expresión de aspectos cosmogónicos (de los orígenes y fundamentos) y cosmológicos (del orden y la estructuración), que formaron parte de la cosmovisión del pueblo Moche hace casi 1600 años.

A partir del análisis de los Temas Complejos, se definieron algunas dimensiones que dentro de estas hay una concatenación de escenas correlativas que fueron enriquecidas con los muros similares que se descubrieron en la Huaca de la Luna.

La propuesta de calendario mítico-ceremonial se sustenta en un análisis de temas que se vinculan con escenas o actividades ceremoniales que están dentro de una estructura narrativa, representados también de manera fragmentada en la cerámica Moche entre los siglos VI y VII d.C.

Considero que una parte de esta contribución se basa en los escritos de Anne Marie Hocquenghem (1987) sobre "Iconografía Mochica", donde encontramos información muy importante sobre el uso de fuentes etnohistóricas e iconográficas, relativas a la vida ceremonial de los Incas para entender el mundo mágico-religioso Moche.

Es preciso indicar que probablemente muchas interpretaciones aquí esbozadas serán revisadas con el tiempo de acuerdo al desarrollo de las investigaciones futuras dentro de un marco comparativo y de complementariedad de los muros descubiertos en las Huacas de Cao Viejo y Huaca de la Luna. Por la información que tenemos y que fue vertida en una publicación anterior (Franco y Vilela 2005), este artículo condensa lo más importante sobre los Temas Complejos para entender sobre su naturaleza

\section{Antecedentes en el Estudio de la Narrativa del Arte Moche}

Antes del descubrimiento de los Temas Complejos en la Huaca Cao Viejo (1990) y después en la Huaca de la Luna (2004), las representaciones polícromas en alto relieve eran desconocidas para el circulo científico, a diferencia de las pinturas murales procedentes de las Huacas de Pañamarca (Valle de Nepeña) y la Luna (Valle de Moche) (Bonavia1985), que por entonces ya eran conocidas y estudiadas, pero no se habían tomado los cuidados necesarios para su conservación futura, tanto que en la actualidad estas pinturas están desafortunadamente destruidas. A través de estas representaciones pictóricas y especialmente de la iconografía de la cerámica, los investigadores tomaron mucho interés en reconstruir la vida político-religiosa de los Moche, con aportes sumamente importantes como las interpretaciones de Donnan (1978, 1999), Hocquenghem (1987), Kutsher (1983), Lieske (1992), Berezkin (1980), Makowski (1994,1996, 2008), Golte (2009), por citar los principales. 


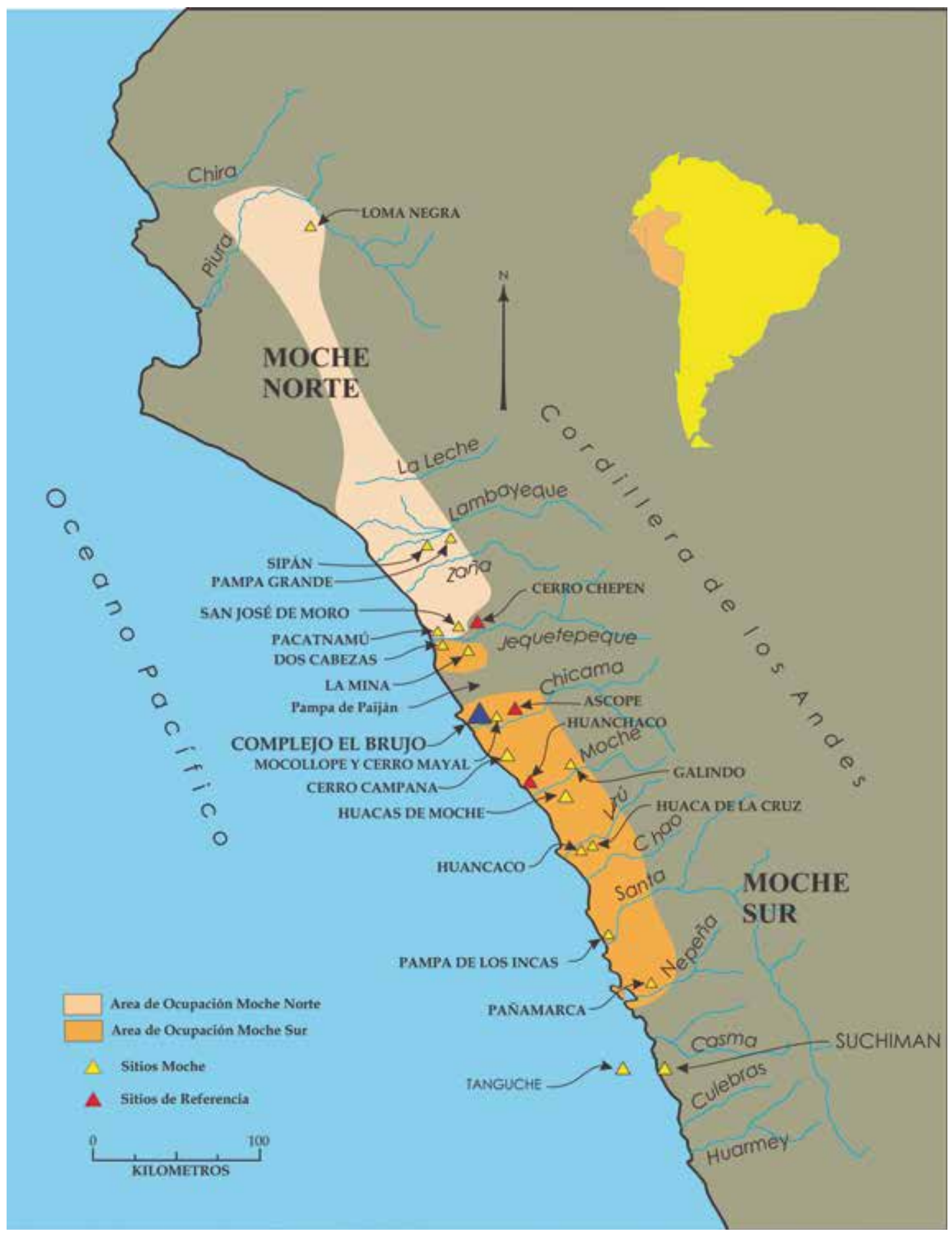

Fig. 1. Mapa de la costa norte del Perú con la ubicación de los sitios Moche 


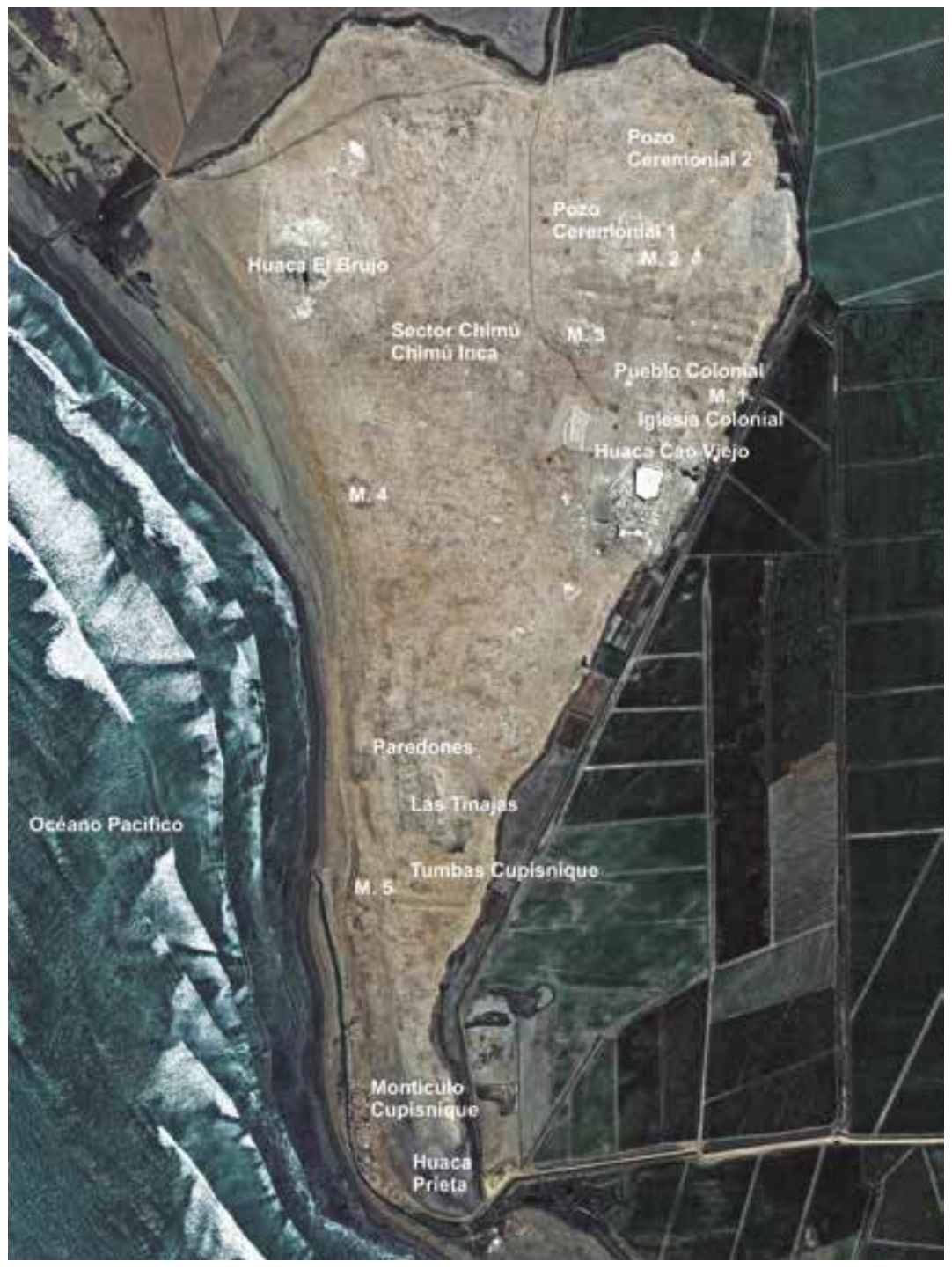

Fig. 2. Foto aérea del complejo arqueológico El Brujo con la ubicación de los sitios más importantes (tomado de google 2015).

Fig. 3. La Huaca Cao Viejo en el Complejo El Brujo (foto de Luis De La Vega).

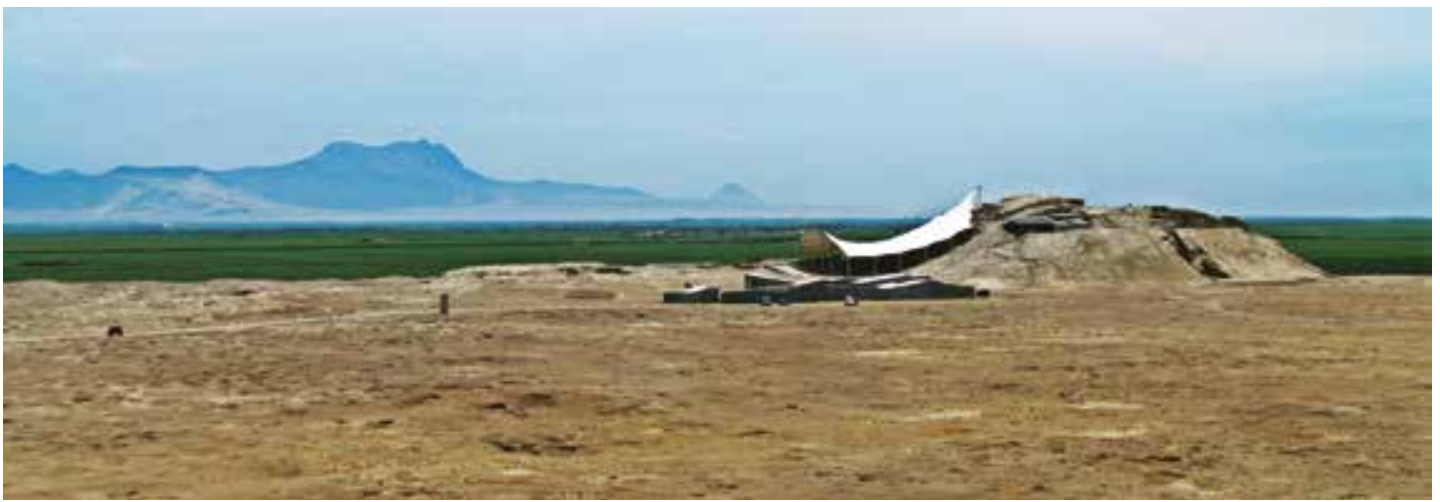


El gran aporte de Christopher Donnan (1978), uno de los investigadores que ha estudiado a los Moche durante toda su vida, ha sido la necesidad de tener una aproximación temática sobre las representaciones pictóricas de la cerámica, al definir un número limitado de temas, entre los cuales el "tema de la presentación" ahora denominado también la "ceremonia del sacrificio", ha cobrado relevancia en cuanto al análisis y significado de este tema central, así como de otros elementos simbólicos que le ha permitido, a través de las imágenes, predecir determinados ritos en la iconografía Moche.

Por otro lado, Anne Marie Hocquenghem (1987), dentro de sus contribuciones valiosas, a veces incomprendida por sus algunos de sus planteamientos, estudió muchos episodios de la iconografía, donde propone como tesis que las representaciones de esta cultura son un sistema de componentes interactuantes que permiten cumplir una función comunicativa y que cada una de éstas se puede entender como parte de todo un proceso ideológico. Aún, cuando hemos visto que Hocquenghem ha sido observada por su exagerada comparación del sistema religioso Moche con lo Inca, considero que su aporte resulta sustancial para comprender muchos aspectos rituales y/o ceremoniales de este tiempo. Esta investigadora ha planteado que muchos patrones de conducta religiosa Incaicos forman parte de una supervivencia del calendario ceremonial andino, que resulta ser todo un sistema de continuidad histórica mantenido por muchos siglos en los Andes Centrales. La iconografía moche a través de la imagen funciona como referencia para establecer un orden ancestral (Hocquenghem 2008: 26). En definitiva, Hocquenghem en la década de los ochenta hace un juicio premonitorio antes de los descubrimientos de los murales en los templos de Cao Viejo y la Luna, cuando señala lo siguiente:

"Los muros de los templos forman parte del marco donde se sitúan estas ceremonias. La función de los soportes de la iconografía es entonces utilitaria dentro del cumplimiento de las tareas rituales... La función de la iconografía mochica, de los objetos en los cuales aparece y de las ceremonias que ilustra, es entonces representar las reglas, encuadrar, estabilizar, preservar las instituciones ancestrales" (Hocquenghem 1987: 84).

Muchos investigadores han tratado de explicar la iconografía Moche utilizando ciertas propuestas o métodos de análisis iconográficos. Por ejemplo, el historiador Panofsky (1979) aplica por primera vez una metodología para el estudio del arte histórico en general, basado en los siguientes procedimientos: descripción pre-iconográfica, análisis iconográfico e interpretación iconológica. Uno de los investigadores que ha utilizado la metodología de Panofsky es precisamente Luis Jaime Castillo (1989), cuando aborda un tema narrativo de "personajes míticos, escenas y narraciones en la iconografía mochica" desde diferentes perspectivas. Castillo ha desarrollado una metodología de descripción analítica pre-iconográfica, adaptada a las características de la iconografía moche (conformación del corpus, identificación de personajes, atributos esenciales, atributos secundarios, análisis de la variabilidad de los atributos de acuerdo a las acciones, correlación fase-acción atributo, etc.).

Krzysztof Makowski $(1994,1996,2008)$ ha aportado en la discusión en torno al carácter de la iconografía, señalando la posibilidad de organizar las imágenes en secuencias narrativas. Su propuesta es que los atributos y rasgos de ciertos personajes centrales cambian de manera secuencial a medida que avanza la narración. Indica además que son episodios concatenados de historias míticas, de héroes divinos que establecen el orden social y político, así como definen la personalidad iconográfica de ciertos actores divinos y humanos. Esta metodología ayuda a separar contenidos narrativos concatenados, que pocas veces se manifiestan en las pictografías de la cerámica, pero con mejores posibilidades ahora en los murales polícromos dentro de los espacios ceremoniales de los templos donde se identifican estas escenas míticas. 
Jürgen Golte $(1994,2009)$ otro investigador de la iconografía moche, ha señalado la posibilidad de organizar las imágenes en secuencias narrativas, y ha sugerido la reconstrucción de discursos religiosos a partir de la gesta y luchas míticas del dios F, así como ha intentado discutir aspectos como el lenguaje simbólico, la cosmovisión moche, las limitaciones metodológicas en la cerámica como contexto. Analiza, asimismo, algunas secuencias narrativas de las divinidades mayores y su descendencia, además de secuencias del entierro, secuencias de ritos de montaña, de fertilidad, etc. con base en la iconografía y su directa vinculación con la forma de las vasijas de cerámica.

Entonces, considerando las propuestas anteriores, a continuación trataré de revaluar el significado de los Temas Complejos, apoyándome en la presentación iconográfica de los muros de la Huaca de la Luna, especialmente del muro mayor, debido a que los dos murales de este edificio se encuentran en un gran estado de conservación (Uceda y Morales 2010; Tufinio 2006). Como se recordará, hace muchos años, ante la ausencia de los murales de la Huaca de la Luna nos propusimos con mi colega Juan Vilela (ver Franco y Vilela 2005), realizar un estudio pre iconográfico de los Temas Complejos, basado en la presentación de los siguientes pasos de la investigación: Metodología, composición, descripción de unidades, tipos de representación y el análisis comparativo de los tipos de representación, procedimiento descriptivo que ayudó, por entonces, a la identificación de personajes a través de acciones o de las relaciones de los elementos interactuantes (rasgos corporales, atributos, personajes, objetos de la escenografía, acciones), dentro de un conjunto de escenas que forman una unidad mayor. Como se comprenderá, nuestra mayor limitación fue la relativa ausencia de otras escenas concatenadas que no aparecían en la parte superior de los murales de Huaca Cao Viejo y que ahora se pueden distinguir en el mural mayor de Huaca de la Luna en el cual se basa nuestra revaluación (figs. 4-5).

Una de las interrogantes todavía por resolver es, ¿cuál fue la causa de la destrucción o desmantelamiento de gran parte de las representaciones que estuvieron en la fachada principal de la Huaca Cao Viejo? Quizá hay muchas hipótesis interesantes que necesitan mayores evidencias de constatación. Tengo la impresión que la destrucción del templo mayor obedece a la imposición de una orden político-religioso de mayor fuerza y poder como para desmantelar la ideología de los nativos expresada en el santuario principal. Todo lo contrario ha ocurrido en la Huaca de la Luna donde por suerte se han conservado los relieves polícromos y con la continuidad de actividades rituales en la época Chimú, con evidencias de altarcillos y otros hallazgos dentro del espacio de los Temas Complejos, tanto que, incluso, se habrían realizado ritos propiciatorios de sangre en los dos murales que culminaron en la destrucción de la parte central e inferior de los dos murales (Ricardo Morales, comunicación personal)

Sin embargo, no quiero culminar esta introducción indicando que Segundo Vásquez (1997), arqueólogo de la Universidad Nacional de Trujillo, que dirigió con nosotros el programa El Brujo en la década de los noventa, hizo un intento preliminar de la descripción de los Temas Complejos de Huaca Cao Viejo, con la identificación de la fauna y flora con nombres científicos presentes en los murales que resulta de algún modo un aporte preliminar importante que no debemos dejar de lado.

En suma, lo que ahora tratamos de presentar es una descripción general y una homologación de las representaciones de los murales con Temas Complejos de las Huacas de Cao Viejo y de la Luna, apoyándonos en el estudio pre iconográfico que se realizó hace muchos años (Franco y Vilela 2005) y en la conformación de un corpus iconográfico de la cerámica Moche y datos etnohistóricos que ayudan a una aproximación interpretativa de ciertas escenas del discurso mítico ceremonial. 


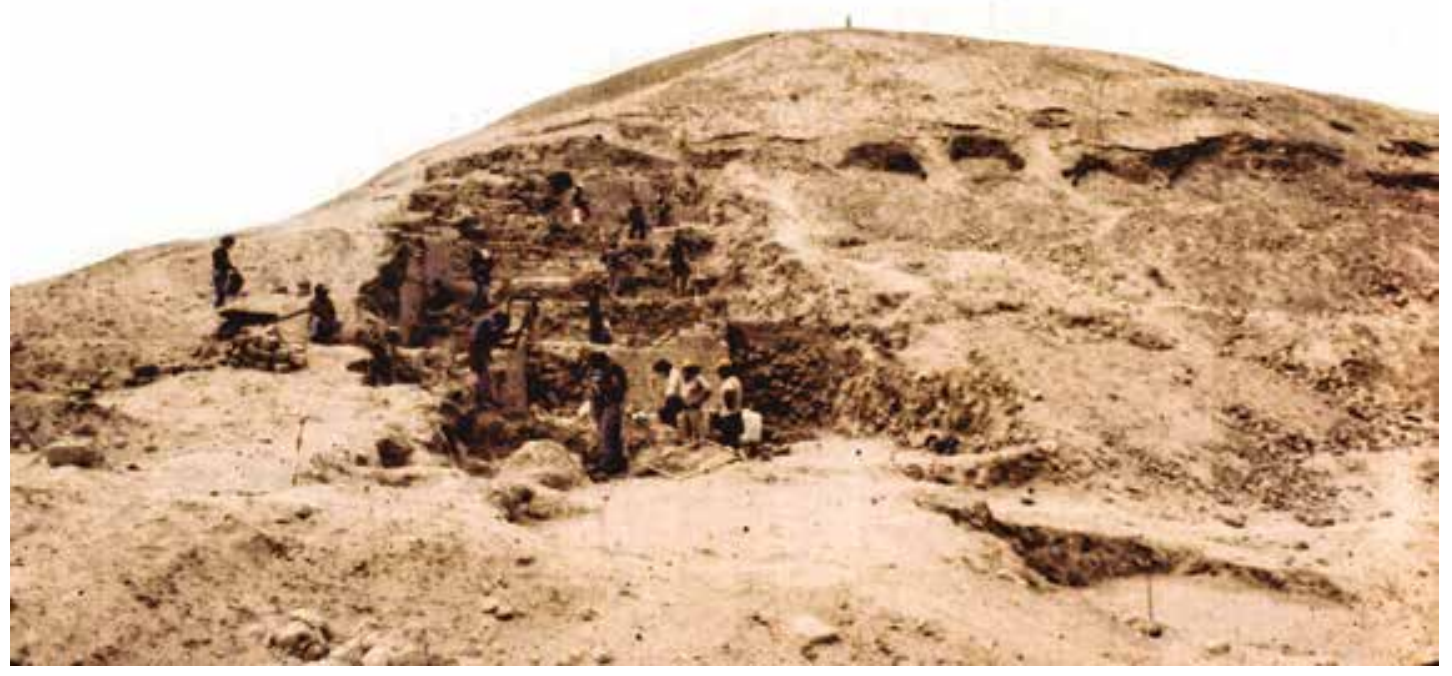

Fig. 4. Excavaciones iniciales en $1990 \mathrm{del}$ recinto esquinero de la plaza ceremonial con los Temas Complejos de la Huaca Cao Viejo

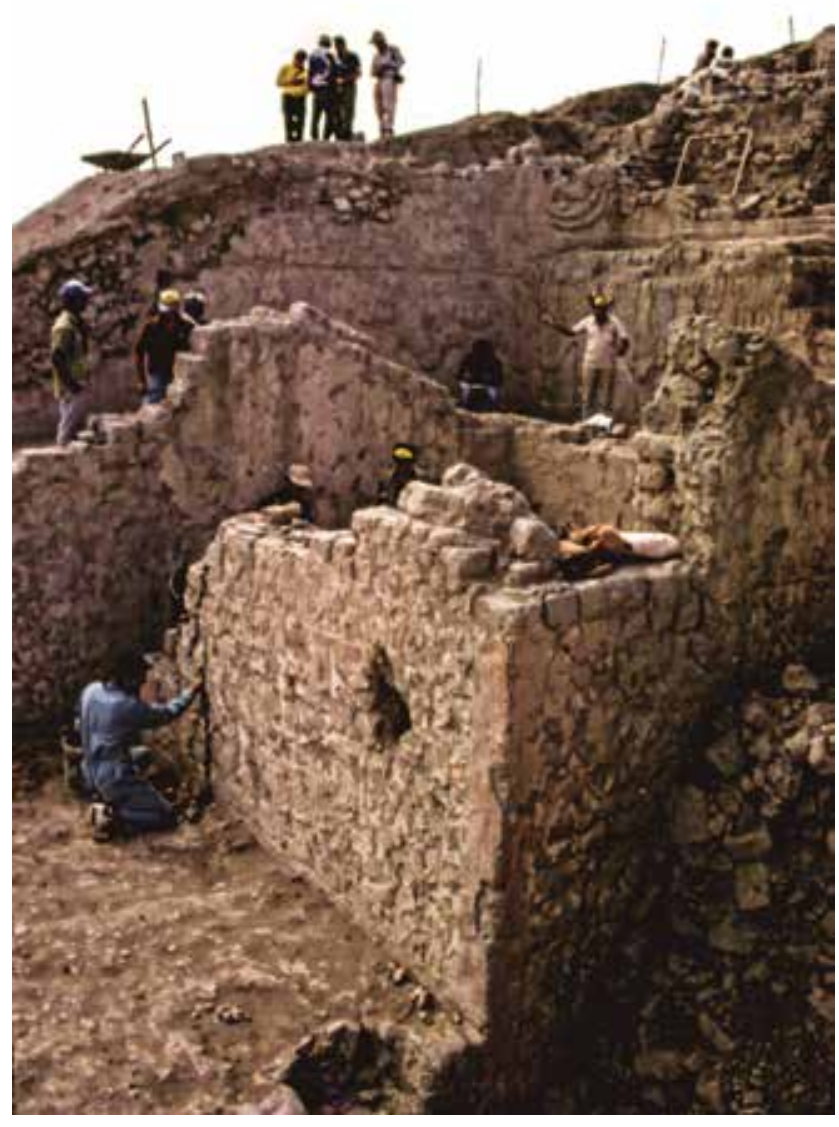

(foto de Régulo Franco).

Fig. 5. Vista en 1990 de las excavaciones del recinto esquinero con el Tema Complejo 1 (foto de Régulo Franco). 


\section{Ubicación, Función y Comparaciones de los Temas Complejos}

Los Temas Complejos 1 y 2 de la Huaca Cao Viejo, o denominadas también muro mayor (2) o muro menor (1), corresponden a dos muros que forman parte de un recinto ceremonial con plataforma delantera y rampa lateral, ubicado en el ángulo sureste de la plaza ceremonial. Uno de los muros se encuentra en la cara norte del recinto esquinero (Tema Complejo 1) y el otro muro se ubica en el lado este del mismo recinto (Tema Complejo 2) (figs. 6-7).

Por la presencia de una cumbrera observada en el Tema Complejo 2 (muro mayor) de la Huaca de la Luna, se puede inferir por analogía que en la Huaca Cao Viejo existió también una cubierta a dos aguas y que en cada cara interior se representaron figuras polícromas asociados al cielo cósmico, debido al hallazgo sobre la plataforma de fragmentos de un cielo raso decorado que había caído después de su abandono, asociado a trozos de porras de cerámica que seguramente estaban originalmente sobre la cumbrera del techo (fig. 8). Hace muchos años, se trató de recomponer la estructura del cielo raso utilizando un programa virtual con el apoyo de IBM y la Universidad Católica del Perú, donde finalmente se comprobó que los casi 5,000 fragmentos registrados no correspondían a la totalidad del cielo raso, sin embargo sí fue posible constatar que algunas figuras observadas en los muros mayor y menor estaban también presentes en el cielo raso (Franco et. al. 1998) (fig. 9). En efecto, en este pequeño espacio no sólo estaban los muros bellamente presentados con toda su compleja simbología, sino también el cielo raso aparecía como una especie de "bóveda celeste" de alto contenido mágico-religioso sin precedentes en el mundo andino (fig. 10).

El sacerdocio moche que presidía las ceremonias, seguramente se ubicaba sobre la plataforma del espacio sacro, donde en su discurso daba lectura de la composición del muro mayor (muro este) que aparecía a modo de un libro abierto con una notable información, que le servía para identificarse con el poder del mensaje contenido en los muros e invocar a las divinidades y así reactualizar el mundo mítico (los principios y la estructuración del mundo). No hay dudas que para los nativos el contenido de los murales era sin lugar a dudas una expresión divina.

Este espacio se habría convertido también en el escenario de la ceremonia de presentación de los guerreros vencidos con sus armas, a cargo de sus captores en la batalla ritual, porque a pocos metros, en la terraza inferior de la fachada principal del templo se encontraba como modelo la representación en relieve de un cortejo de guerreros vencidos y vencedores que van precisamente en dirección al recinto esquinero que contiene los Temas Complejos. Algún guerrero mayor, o quizás algún prisionero, subían también a la plataforma utilizando un peldaño que se ubica al pie de la esquina noroeste del recinto esquinero (fig. 11).

Se ha indicado que el Tema Complejo 1 de Huaca de la Luna (muro este) es similar al Tema Complejo 1 de Huaca Cao Viejo (muro norte), y que el Tema Complejo 2 de Cao Viejo es similar al Tema Complejo 2 de la Huaca de la Luna (ver Sánchez 2012: 51); esto no es verdad, porque el Tema Complejo 1 de la Huaca de la Luna (muro mayor) se compara con el tema Complejo 2 de la la Huaca Cao Viejo (muro mayor), en tanto, el Tema Complejo 1 de la Huaca Cao Viejo no es similar en estructura al Tema Complejo 1 de la Huaca de la Luna (ver Tufinio 2006); este último mural es incompleto en su mensaje y está lejos de una buena culminación artística a diferencia del Tema Complejo 1 (muro menor) de la Huaca Cao Viejo.

Conviene indicar que algunas imágenes presentes en el Tema Complejo 2 (muro mayor) de la Huaca Cao Viejo no se encuentran en el Tema Complejo 2 de la Huaca de la Luna (muro mayor), porque hay ciertas diferencias en la ubicación de los elementos iconográficos, pero a pesar de ello, se puede 


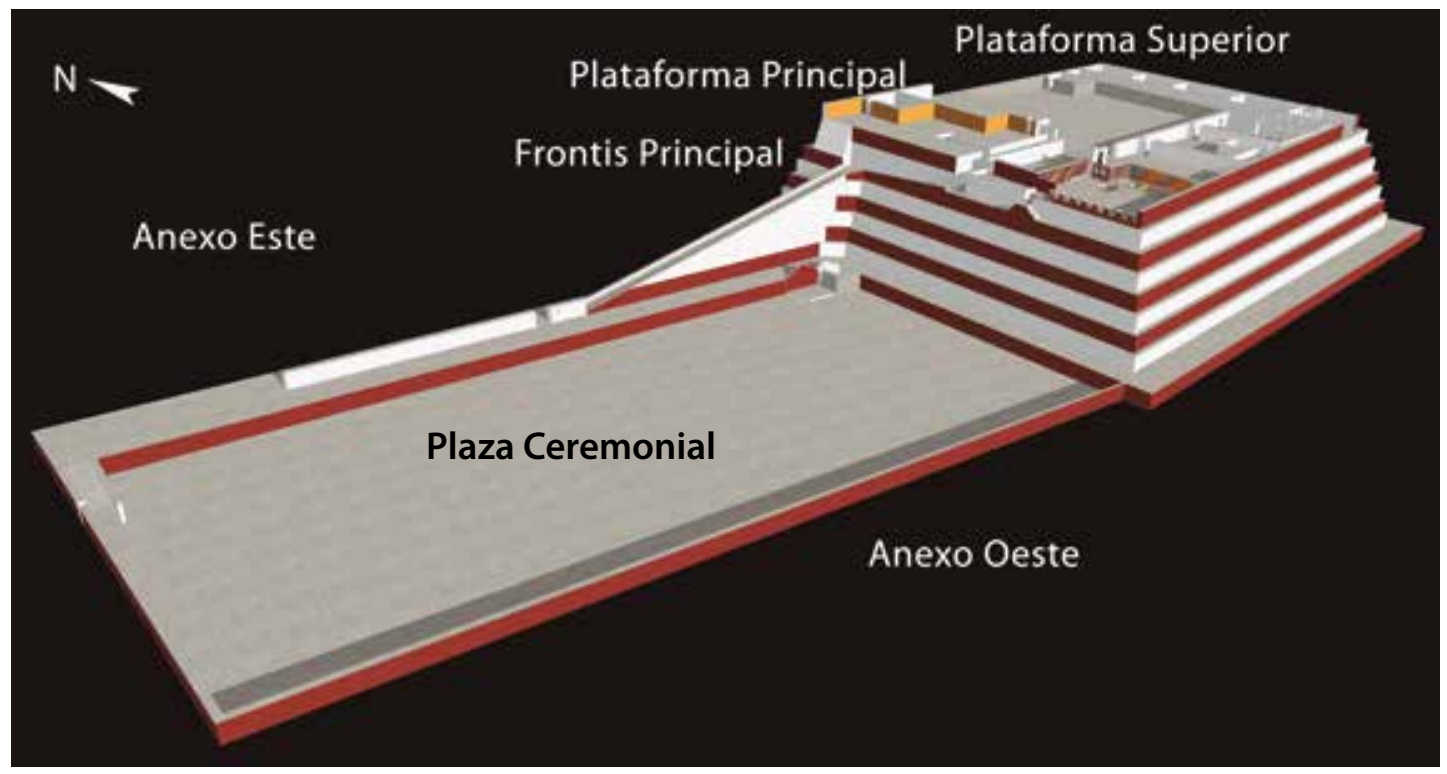

Fig. 6. Reconstrucción hipotética de la Huaca Cao Viejo con sus componentes arquitectónicos y la ubicación de los Temas Complejos (ilustración de Luis De la Vega).

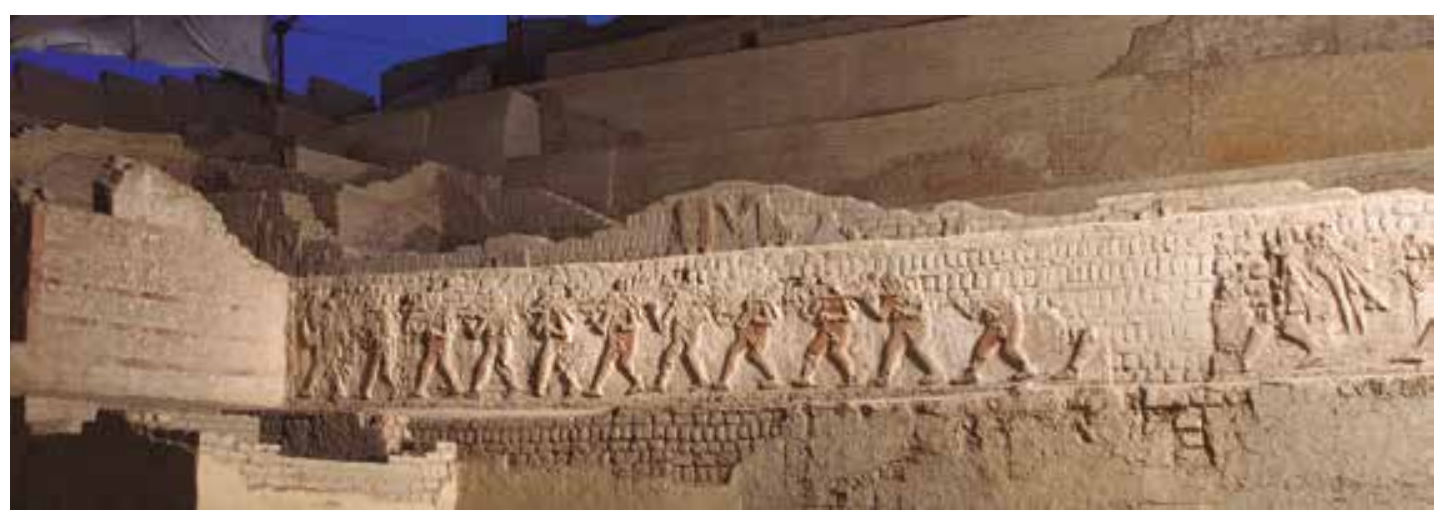

Fig. 7. Vista general del recinto esquinero con los Temas Complejos en la Huaca Cao Viejo.

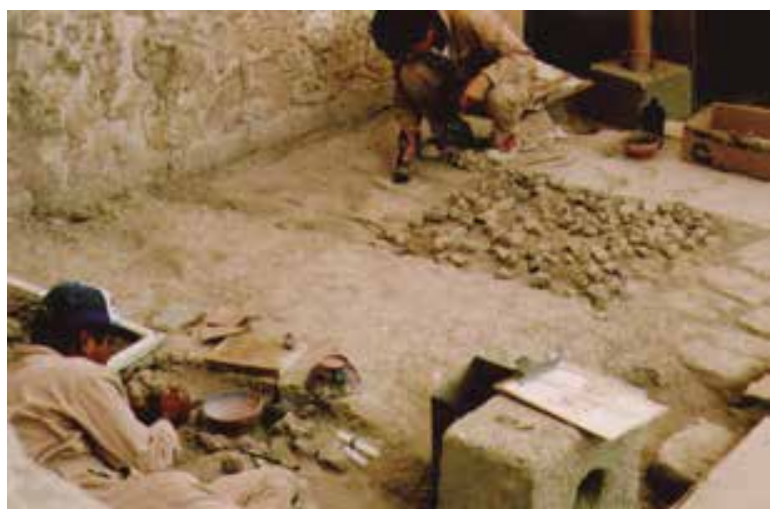

Fig. 8. Excavaciones en la plataforma delantera del recinto esquinero, en proceso de recuperación de los fragmentos del cielo raso (foto de Régulo Franco). 


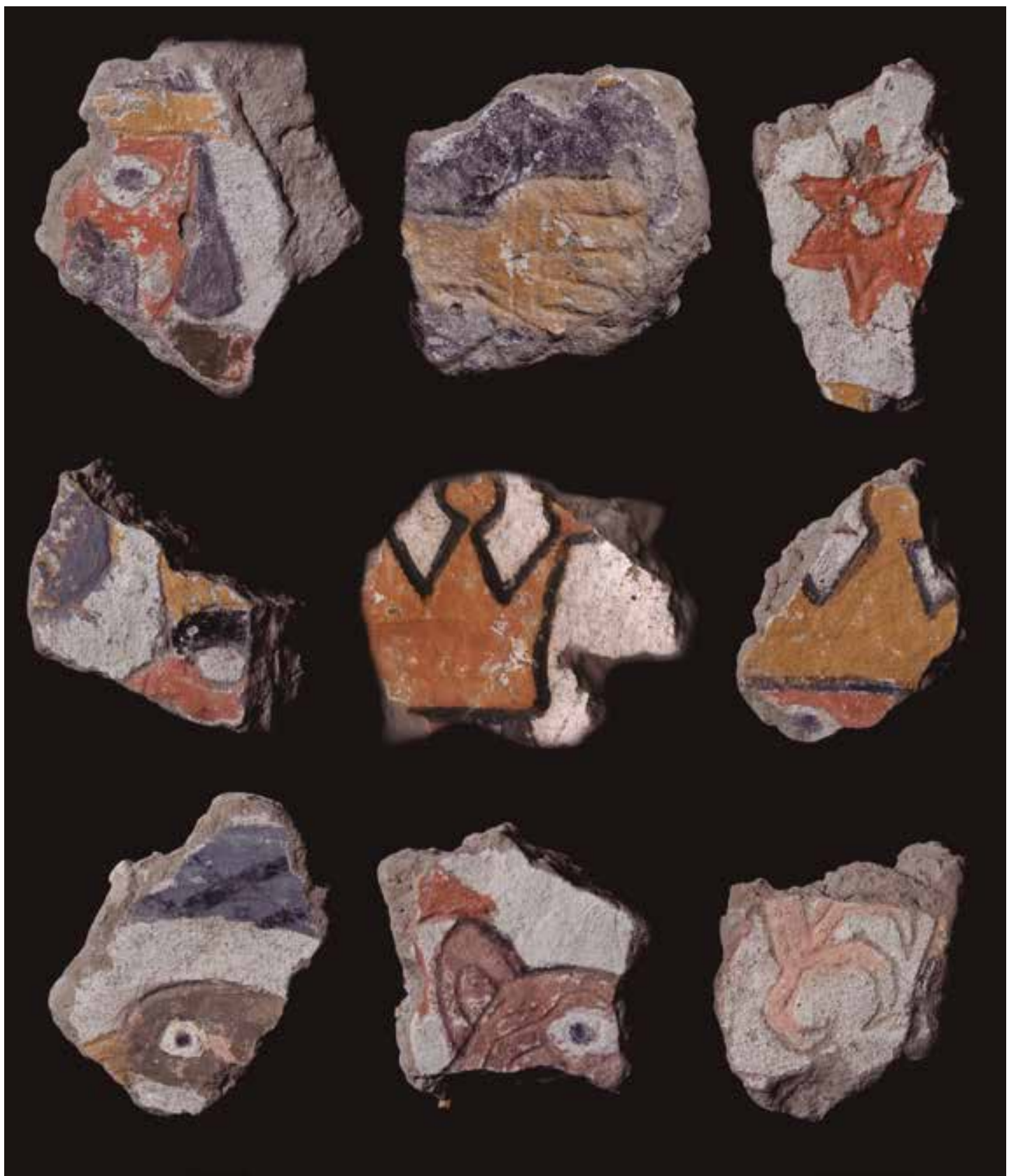

Fig. 9. Fragmentos con motivos incisos y pintados del cielo raso que fueron recuperados de las excavaciones de la plataforma delantera del recinto esquinero (archivo Fundación Wiese). 


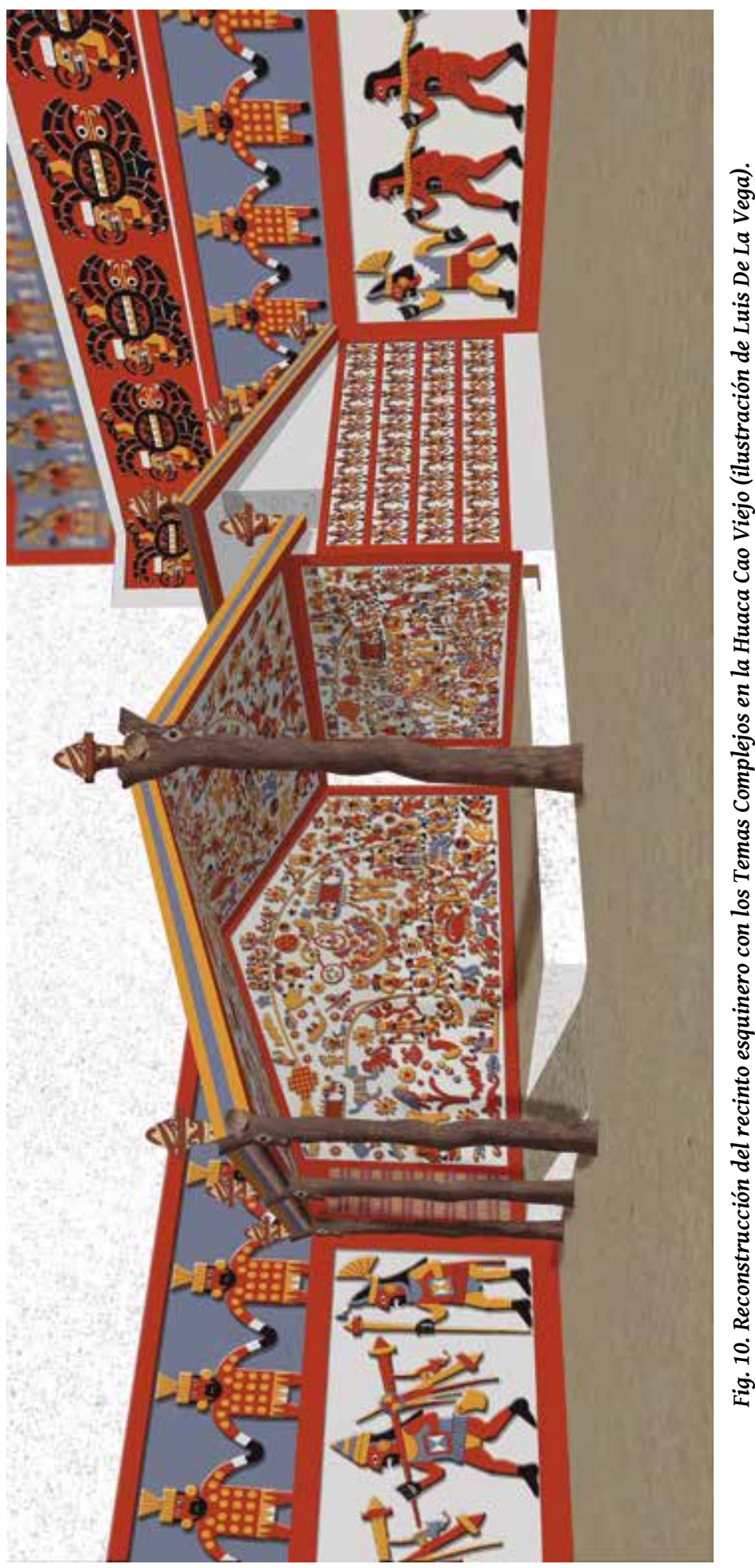




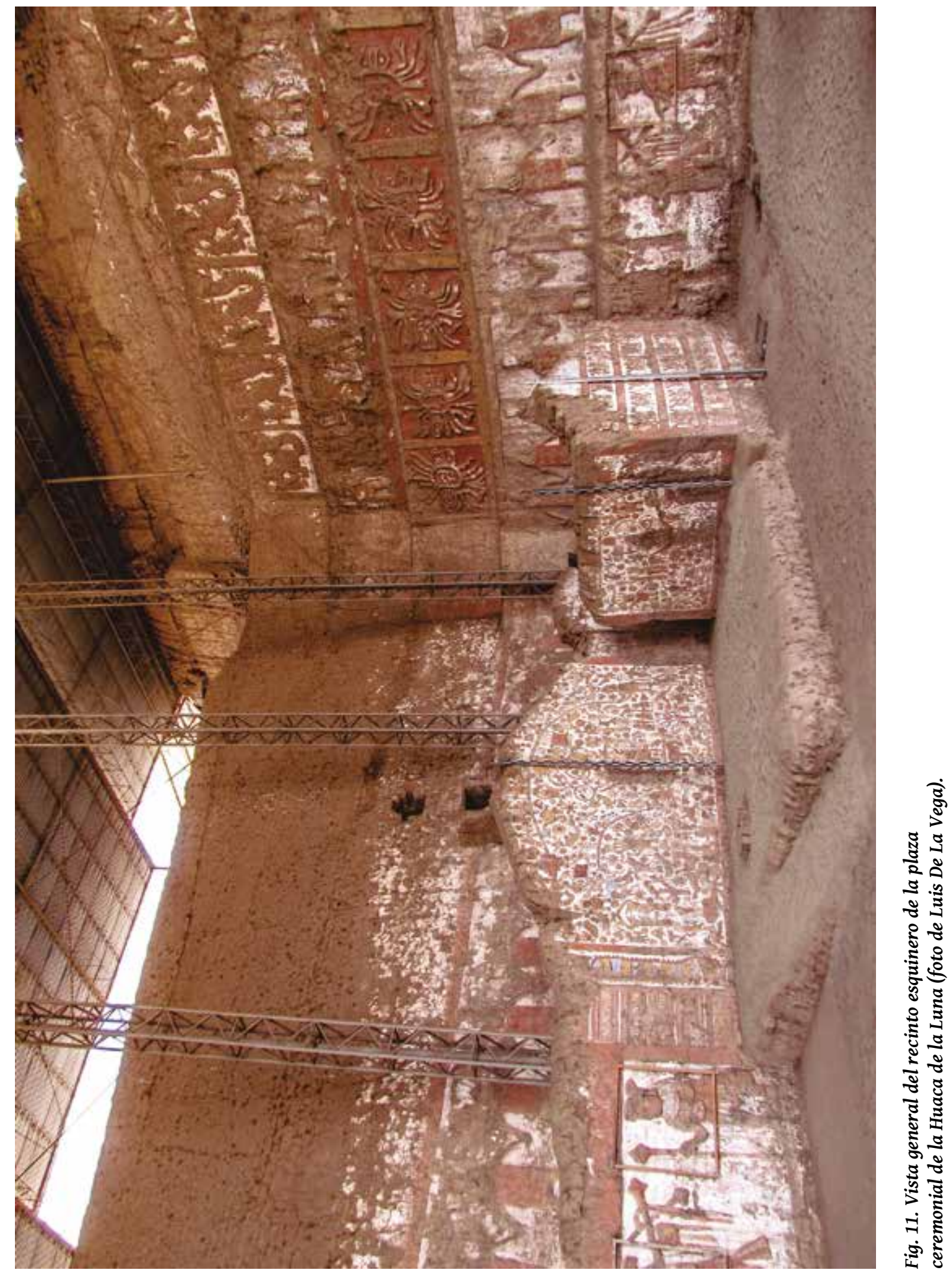


deducir que el discurso general contextual tiene el mismo contenido, no hay diferencias. Lo que sí está bastante claro es que el acabado estructural de los motivos en los murales de ambos edificios es diferente, que nos permite ahora deducir que se tratan de dos escuelas de artistas distintos, unos del valle de Moche, menos precisos en su oficio, y otros del valle de Chicama, donde se registra mucha calidad artística en la elaboración de los murales polícromos; esta distinción puede quizás ayudar a distinguir alguna diferencia de poder entre ambos sitios.

\section{El Simbolismo de los Temas Complejos como respuesta a un nuevo orden}

El funcionamiento de las Huacas de Cao Viejo y la Huaca de la Luna en el Siglo VII d.C., corresponde a una expresión de estabilización ideológica del sistema político-religioso en general, después de una etapa de crisis que vivieron los Moche anteriormente, y que de acuerdo a las evidencias en la Huaca Cao Viejo, implicó primero la construcción de un edificio de emergencia no culminada, cubriendo por completo el edificio anterior que tenía relieves polícromos en toda su fachada principal, con escenas distintas a las de la Huaca de la Luna. Los acabados y la obra en general del edificio de emergencia, o de transición, es de poca calidad y oficio, donde incluso, se registraron grandes trazos incisos sobre el piso de la plaza (un doble círculo y líneas dirigidas al este y oeste) y evidencias de la realización de algunos ritos al parecer vinculados con el culto al agua o la luna.

La construcción transitoria o de emergencia del templo (cuarto edificio) fue antecedido por fuertes lluvias que formaron gruesos sedimentos al pie de los muros con los relieves de los oficiantes en la terraza inferior de la fachada principal asignado al tercer edificio (Franco et. al. 2001: 146-167). Muchos investigadores han constatado la presencia de esta crisis climática en la costa norte del Perú por efecto de un fenómeno pluvial intenso (fenómeno ENSO) y una gran sequía que atravesó la sociedad Moche en el siglo VI d. C. (Shimada et. al. 1991).

Hay algunos análisis de la cerámica con respecto a los cambios iconográficos producidos en esta época, que ayudan a comprender el porqué de la materialización del simbolismo de los Temas Complejos como respuesta a un nuevo orden, después de la crisis. Estos cambios repercutieron en la arquitectura general de los valles de Chicama y Moche. Bawden (1994:403), uno de los especialistas sobre la ideología Moche, indica que en la fase de la cerámica Moche $\mathrm{V}$, considerada la última fase estilística de la cerámica, desaparecen muchas figuras claves de la iconografía ritual temprana, para reemplazarlas por otras nuevas que representan una forma de reconstituir el orden social, que tendría relación con "una respuesta ideológica al stress".

Ahora podemos deducir que cuando los templos Moche de los dos valles contiguos entran a una nueva fase de reestructuración del orden, muestran por primera vez en sus fachadas un discurso donde se unen representaciones del mundo mítico o fabuloso en los niveles superiores con representaciones del mundo terrenal en los niveles inferiores, y es precisamente en este contexto que se inscriben los Temas Complejos como modelo ideológico del gran cambio en respuesta a la crisis y en consecuencia la introducción de un nuevo orden.

\section{LOS TEMAS COMPLEJOS Y SU COMPOSICIÓN ESTRUCTURAL}

Antes de empezar a realizar el análisis, es necesario tener conocimiento de las dimensiones de los Temas Complejos de la Huaca Cao Viejo. El muro menor tiene en la base $3.80 \mathrm{~m}$ de largo por una altura conservada de $2.30 \mathrm{~m}$, pero se estima que tuvo posiblemente una altura de $2.70 \mathrm{~m}$. El muro mayor tiene en la base $5.74 \mathrm{~m}$ de largo por una altura conservada de $2.23 \mathrm{~m}$, con una altura original difícil de estimar, quizás muy cerca de los $4 \mathrm{~m}$. (figs. 12 -17). 

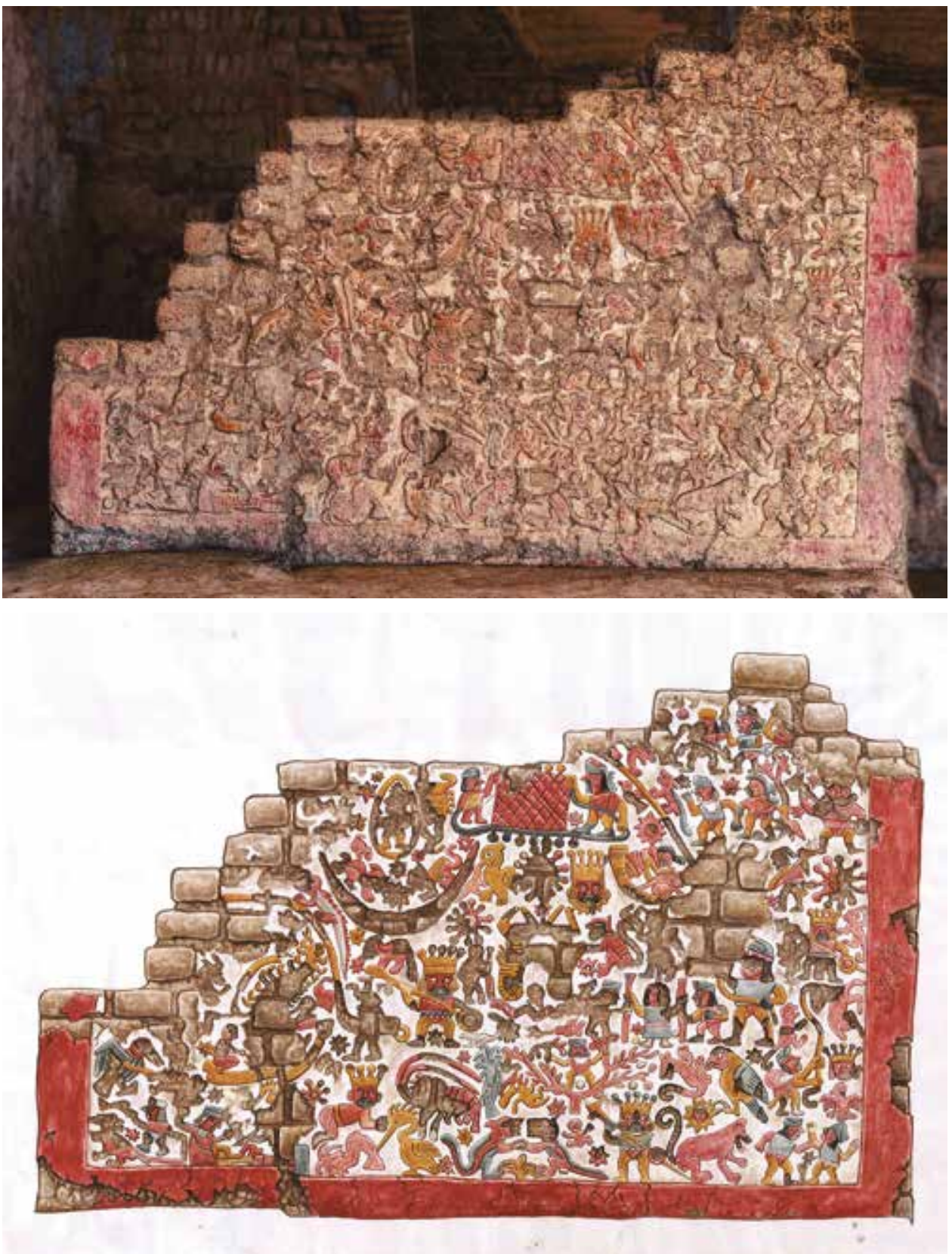

Arriba: Fig. 12. Vista del estado actual del Tema Complejo 1 (muro menor) de la Huaca Cao Viejo (foto de Luis De La Vega).

Abajo: Fig. 13. Dibujo a color del estado actual del Tema Complejo 1 (muro menor) de la Huaca Cao Viejo (ilustración de Segundo Lozada). 


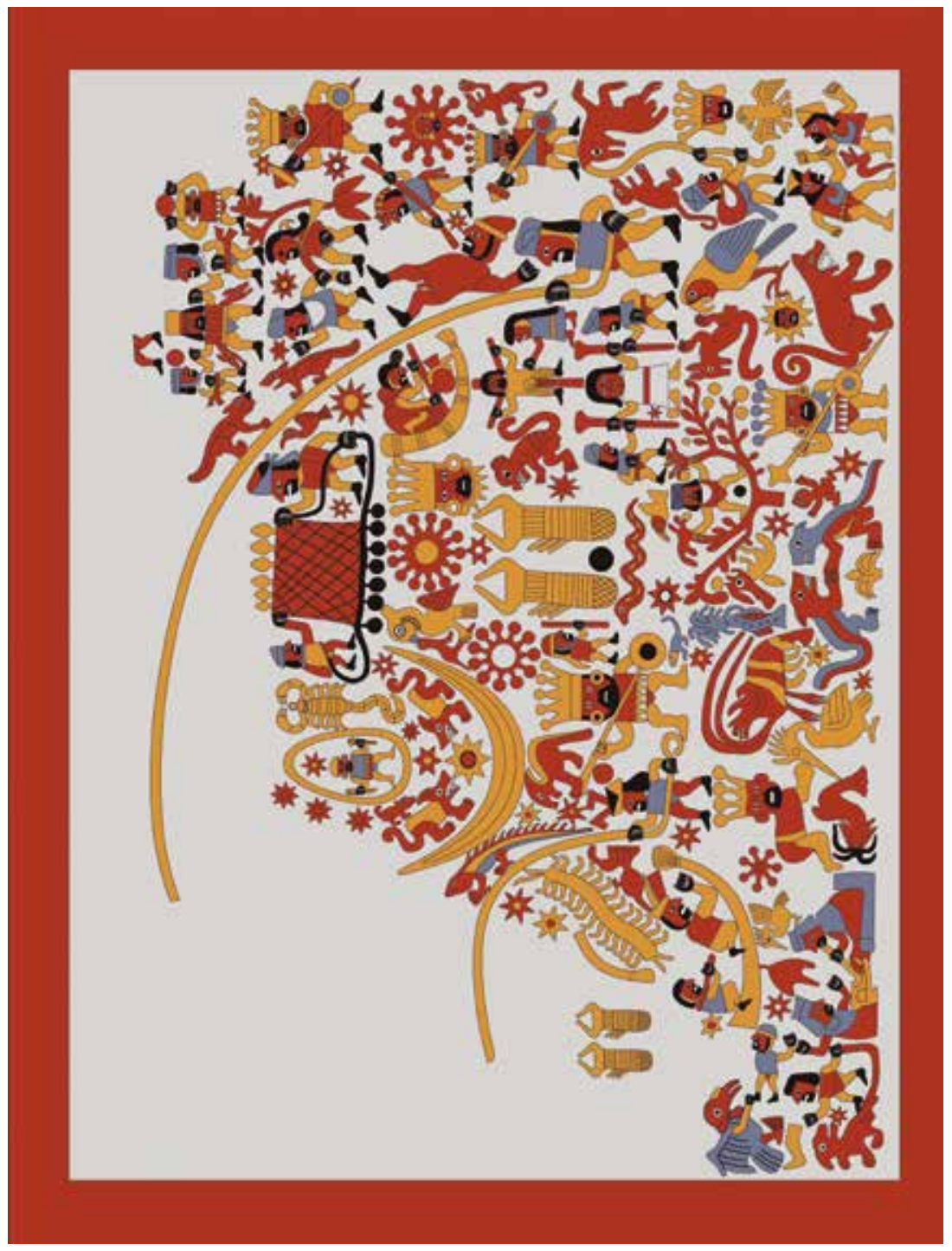

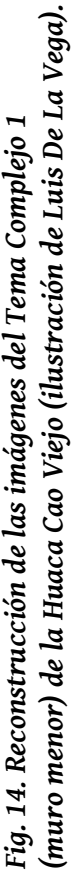




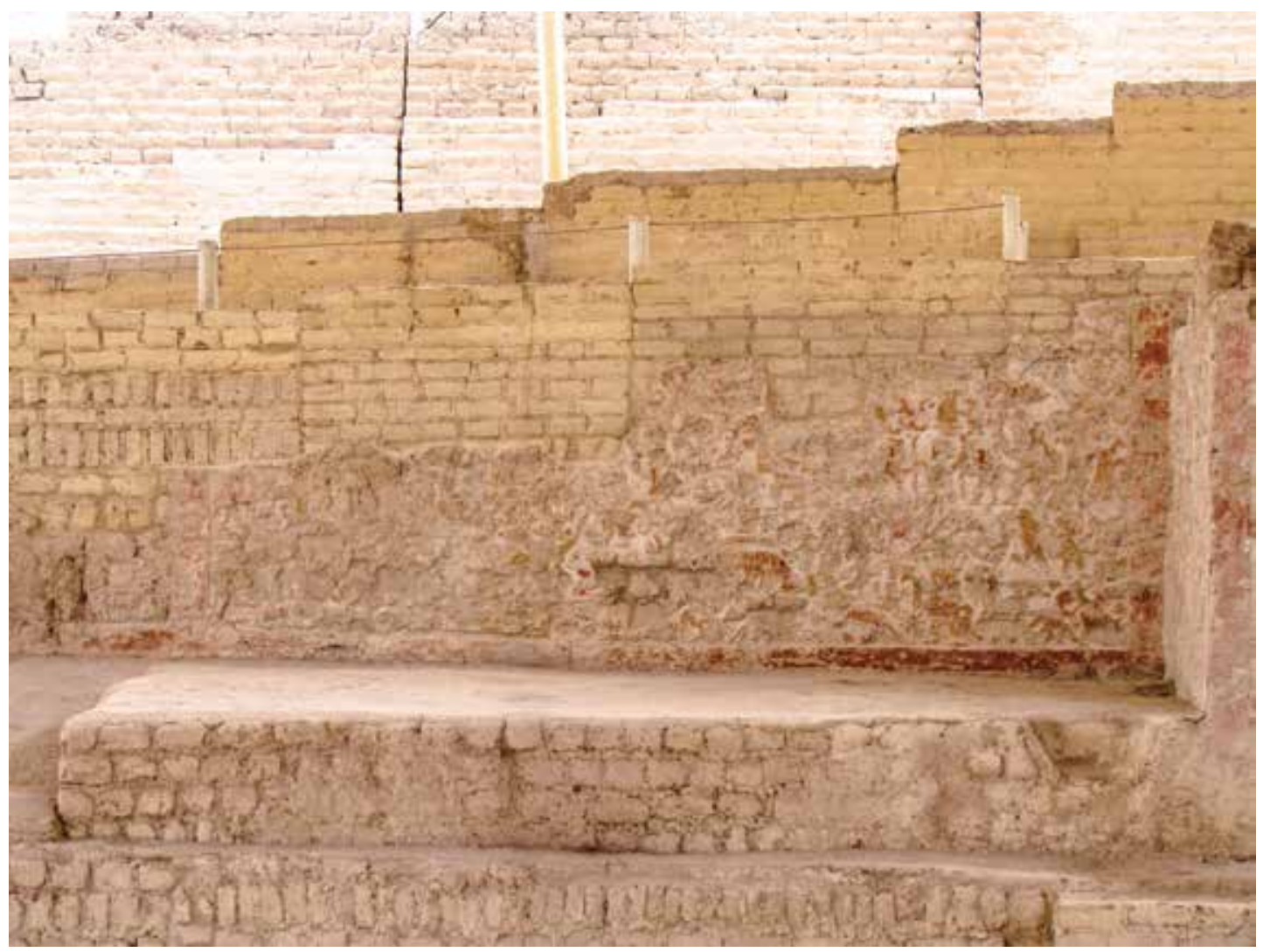

Fig. 15. Vista del estado actual del Tema Complejo 2 (muro mayor) de la Huaca Cao Viejo (foto de Douglas Juárez).

Siguiente página

Arriba: Fig. 16. Dibujo del estado actual del Tema Complejo 2 (muro mayor) de la Huaca Cao Viejo. (Ilustración de Segundo Lozada). 

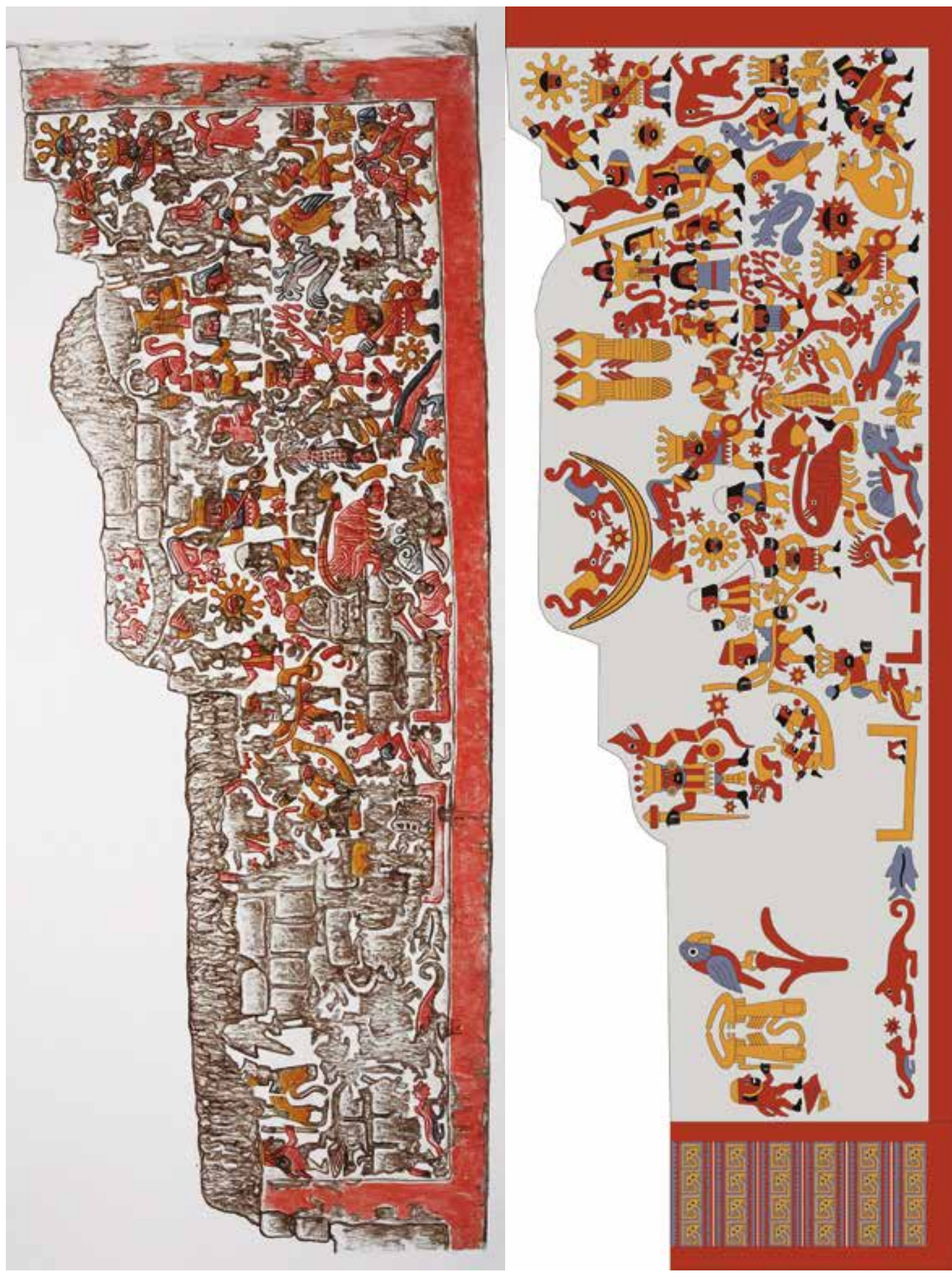
En el caso de los Temas Complejos de Huaca de la Luna se tiene las siguientes dimensiones: El muro menor tiene en la base $2.90 \mathrm{~m}$ de largo por una altura de $2.40 \mathrm{~m}$. El muro mayor tiene en la base 5.23 $\mathrm{m}$ de largo por una altura de $3.45 \mathrm{~m}$ cuyas medidas son tomadas de la base hasta el vértice central (figs. 18-22).

Podemos separar en los murales de las Huacas de Cao Viejo y la Luna, con mayor evidencia en el Tema Complejo 1 de Huaca de la Luna por estar entera, tres campos delimitados por medio de dos sogas cogidas por personajes míticos (ver Tufinio 2006: 55-56; Dolorier y Casas 2012: 143-144), que encierran espacios explícitamente definidos (escenas y diseños asociativos), que se ubican en niveles y orientaciones distintas: superior-inferior; arriba-abajo; izquierda-derecha o viceversa bajo el concepto de "Pacha", que se refiere a las nociones de "mundo", "plano" o "espacio-tiempo", formando "estructuras narrativas" con una secuencia del mundo cosmogónico (orígenes y fundamento) y cosmológico (orden y estructuración).

A mi modo de entender, hay tres campos visibles definidos por las sogas:

Un campo superior que tiene que ver con las divinidades o divinidad suprema, que al parecer tiene una secuencia de abajo hacia arriba (combates, ofrendas, ritos de expiación, rito de pasaje), que involucra al plano terrenal y marino con el mundo de arriba que es el mundo celeste de las divinidades y de los ancestros.

Un campo central se relaciona con el mito de creación (el numen, las pléyades, el huevo cósmico, las luminarias, la luna, las divinidades fertilizadoras, etc.) y la creación de todas las subsistencias terrestres y marinas. Destacan en este campo, y especialmente en las otras, las figuras estelares del cielo nocturno y las flores de loto (Nymphaea sp.) que crecen sobre las aguas costeras, que tuvieron una significación especial para los moche. La flor de loto, al parecer, ha sido un símbolo sagrado vinculado con las divinidades y la creación del mundo, seguramente con los mismos conceptos que se le asigna a las mitologías de la India, China y el antiguo Egipto, especialmente ahora la budista y griega. El proceso de vida de esta hermosa flor probablemente se vincula con algún cambio lunar. En la iconografía moche se encuentra asociada a un rito que ha sido caracterizado como "El lanzamiento de las flores de loto" (ver Golte 2009: 243-248), que consistía en lanzar flores de loto hacia arriba con una estólica, de tal manera que las flores amarradas a un peso caían a manera de un paracaídas. Jürgen Golte quien ha estudiado un poco más este tema, piensa que este era un rito que tenía que ver con ofrendas al mundo de arriba.

Un campo inferior o terrestre se relaciona con todos los seres creados, con los ritos de propiciación del mundo doméstico, con ritos de expiación, sacrificios humanos, que representa, sin duda, un plano en estrecha conexión con el cielo nocturno, estelar, entre los seres vivos terrenales con los seres luminares de la bóveda celeste o el cielo nocturno.

Los tres campos divididos por las sogas, tienen diversas escenas que señalan una directa conexión del mundo "real" con el mundo "fabuloso" o "mítico" (ver Hocquenghem 1987: 190; Makowski 2001: 175-176). Una posición diferente es la visión del mundo en dos planos relacionados y complementarios, que formaron parte de una concepción ideológica que data desde antes de la ocupación moche. A opinión de Rodolfo Sánchez (2012: 33), hay una base conceptual respecto a la visión del cosmos, constituido por dos espacios primordiales: el "Hanaqpacha...que es el mundo de arriba con seres de poder, fundadores, o animadores de la vida en la tierra, con participación de seres del inframundo o Ukhupacha, con los cuales se espera continúen teniendo periódicos encuentros de complementación que conocemos como tinku" 

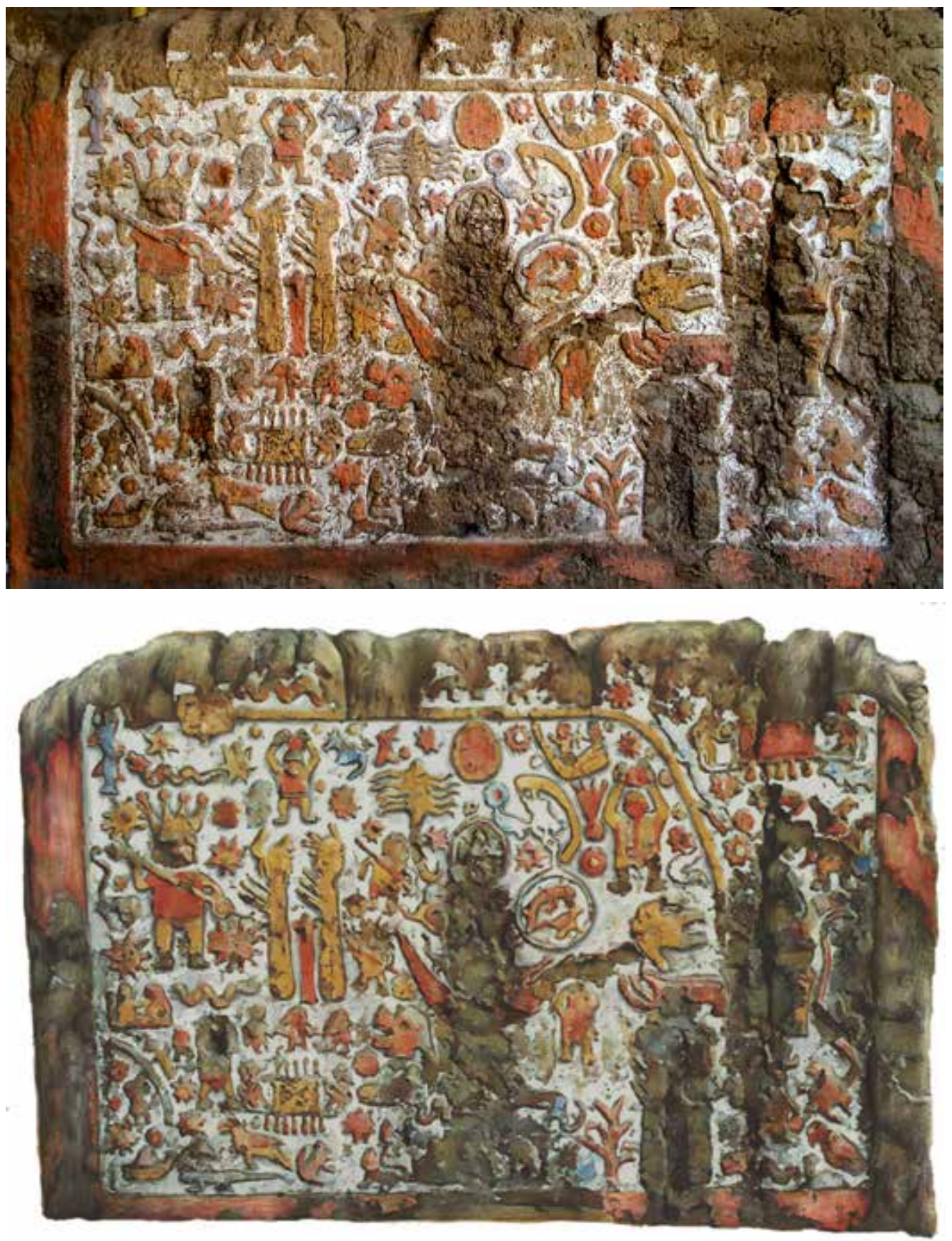

Arriba: Fig. 18. Vista del estado actual del Tema Complejo 1 (muro menor) de la Huaca de la Luna (foto de Luis De La Vega).

Abajo: Fig. 19. Dibujo del estado actual del Tema Complejo 1 (muro menor) de la Huaca de la Luna (ilustración de Jorge Solórzano). 

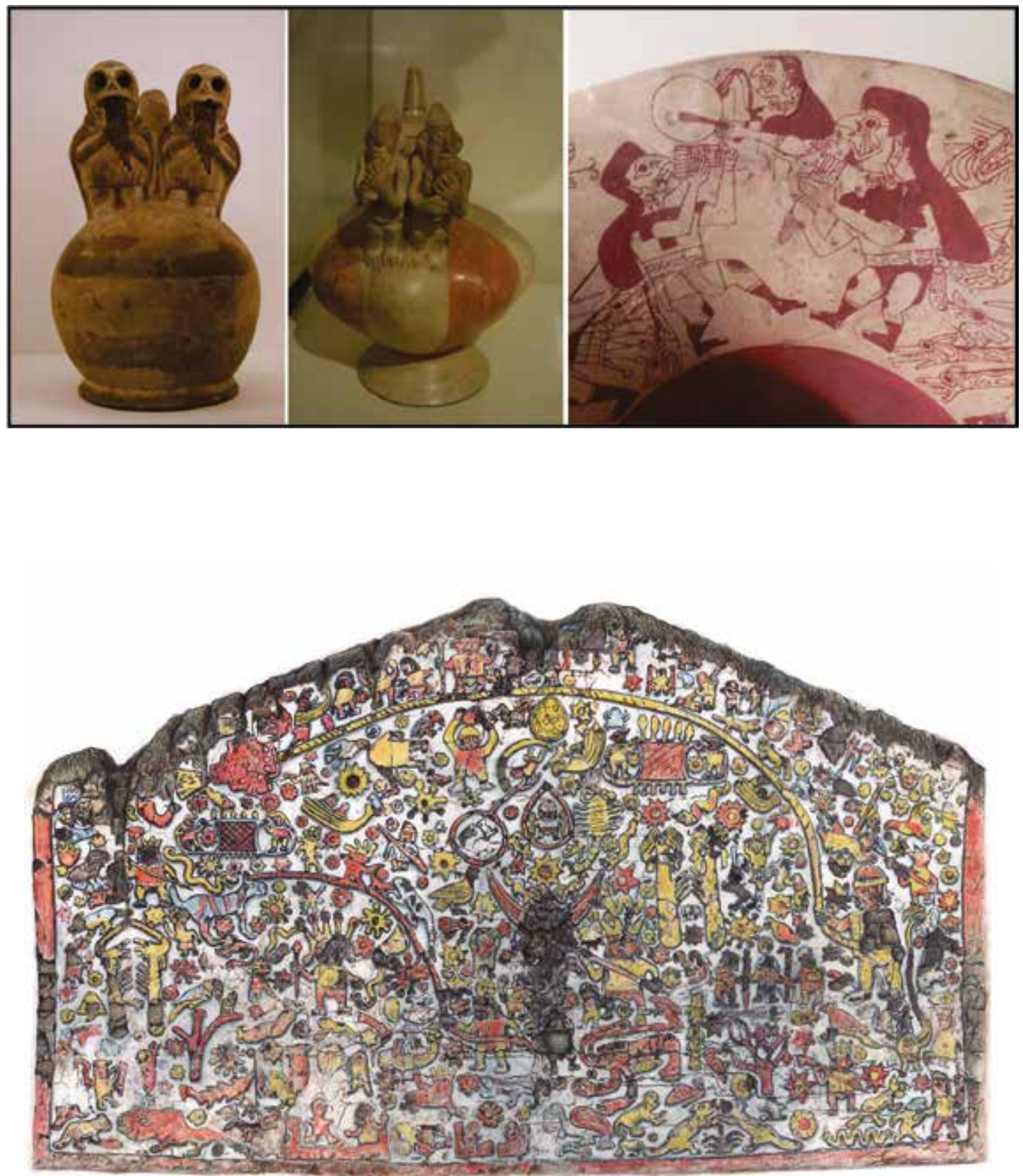

Arriba: Fig. 20. Vista del estado actual del Tema Complejo 2 (muro mayor) de la Huaca de la Luna. (Foto de Luis De La Vega). de la Huaca de la Luna (ilustración de Jorge Solórzano). 


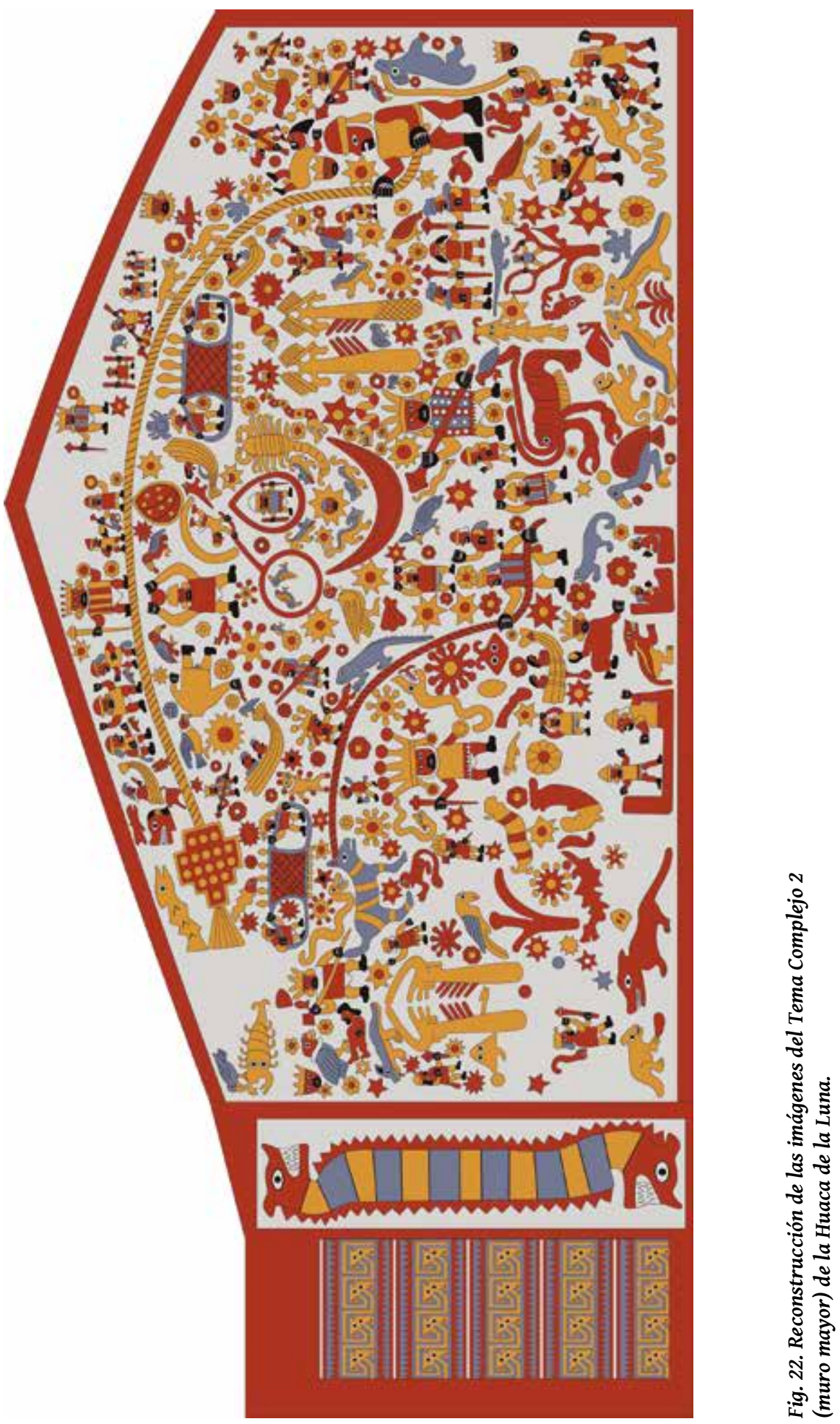


En el mural mayor de Huaca de la Luna se observan más representaciones que no se encuentran en el mural menor de Huaca Cao Viejo. Así como algunas de las representaciones de la parte inferior del muro mayor de Cao no aparecen en la parte inferior del muro mayor de la Luna. Incluso, se advierte que muchas representaciones presentes en los dos muros no guardan necesariamente una ubicación similar, hay diferencias. Pero es necesario, decir también, que el mural menor de la Huaca de la Luna tiene un discurso general incompleto, sin orden, con relación al resto de los murales, donde además se percibe una inmejorable labor en la ejecución de las figuras en relieve.

En general, las representaciones en los Temas Complejos (escenas de navegación, personaje con báculos, seres sobrenaturales, aves, ritos de expiación, etc.), refleja la cosmovisión mítica de los nativos de la costa Norte del Perú en el siglo XVI: "así como abajo es arriba". El cronista Bernabé Cobo (1956 [1653?]: 159) recogió de los nativos de la costa norte la siguiente versión: "había el criador señalado... de todos los animales y aves de la tierra había en el cielo un símil que atendía a la conservación y aumento dellos, atribuyendo a este oficio y ministerio a varias constelaciones de estrellas".

Era natural que los nativos pensaran que los seres vivos de la tierra tenían en el cielo a sus progenitores encargados de su mantenimiento y multiplicación, y que los fenómenos luminares, estrellas, representaban ciertos animales y seres a los cuales se les rendía mucha veneración o culto (ver también Tello 1967: 164-166).

En el muro mayor de la Huaca de la Luna, una de las sogas de color amarillo y de mayor longitud, sujetada por un personaje mítico, culmina en una figura geométrica de lados escalonados y cola, con círculos pequeños en su interior, que se asemeja mucho a la figura del símbolo milenario de los Andes Centrales conocido como la "Chakana", que probablemente tiene la función de nexo entre la tierra y el mundo estelar, que permiten el acceso al centro de la vía láctea (Sánchez 2012:36)(fig. 23).

La otra soga sujetada por otro personaje está unida a un perro sin pelo en un plano superior, rodeado de una serpiente que lo acecha y cuatro figuras estelares alineadas, que puede tener quizás una significación astral de cambio y reestructuración de contenido análogo a los jaguares con la luna. Este tipo de perro "viringo" no se encuentra en el imaginario moche de las fases tempranas, aparece por primera vez en la costa norte aproximadamente hacia el siglo VIII d.C., vinculado con el gran cambio ideológico e influencias (ver Cordy-Collins 2003). La ubicación de este cánido o "perro lunar" en alusión a ciertos mitos, alude posiblemente a un auxiliar de las divinidades estelares, tanto que se cree que el aullido de los perros en los Andes tiene la virtud de generar la recuperación del poder o forma del Sol como la Luna frente a los eclipses o fases lunares (Sánchez 2012:48).

Sobre una de las sogas que se encuentra en el plano inferior del lado izquierdo, hay en asenso una iguana con escamas dentadas en la espalda (Iguana iguana) (ver mural menor de Huaca Cao Viejo) que se enfrenta a un personaje mítico, quizás estelar, al parecer metamorfoseado en una planta o tallos alimenticios, acompañado de una iguana de menor magnitud. Detrás del personaje mítico, aparecen tres estrellas vinculadas con el origen de los nativos de la costa norte señalada por el cronista Antonio Calancha y que lo comentaremos en los siguientes párrafos. La iguana aparece en las escenas de sacrificio de montaña (Ver Franco 2014) y podría tener relación con una representación en relieve de una iguana gigante que se enfrenta a un guerrero moche en actitud de combate que aparece en el muro de la primera terraza lateral este de la plaza ceremonial de la Huaca de la Luna (ver Tufinio 2006: 48: fig.62).

La iguana es muy importante en la iconografía Moche en su versión antropomorfa, se considera que el sacerdote iguana es uno de los principales oficiantes y casi siempre se presenta interactuando con el personaje cara arrugada y un perro. Participa en las escenas de "badminton ceremonial" (Don- 
nan 1978, fig. 6.144) (fig. 24); en la escena de juego; en la escena de unión del ancestro mítico con el personaje femenino; en la escena compleja del entierro; lleva una llama para el sacrificio y entrega ofrendas de conchas para el ancestro mítico; participa también de manera antropomorfa en las escenas de sacrificio humano en montañas y en olas escalonadas.

Sobre la soga más larga sujetada por otro personaje vinculado con el plano superior, aparece el enfrentamiento de dos zorros (visto mejor en el muro menor de Huaca Cao Viejo), uno que sube y otro que baja, que podría tener relación, a juzgar por las opiniones de Rodolfo Sánchez $(2012: 42,43)$ y Alfredo Narváez (2011: 121-124), con animales emisarios que propician los alimentos en el mundo doméstico.

Es interesante advertir, también, que en el tema del entierro, las sogas que aparentemente "extraen el ataúd" rematan en cabezas de zorros o simplemente las sogas se convierten en serpientes con cabezas de zorros que tienen una trayectoria hacia arriba, acompañado de manchas circulares que corresponderían a la expresión simbólica de la sublimación (ver Donnan y McClelland 1999, fig. 6.152) (fig. 25).

La representación de un arco con cabezas bicéfalas de zorros que dicen mucho de la dimensión espacial se encuentran en varias escenas de masticación de coca a cargo de sacerdotes que claman o invocan al cielo o realizan prácticas rituales para pedir lluvia o agua y fructifique la tierra. La probabilidad, en este caso, es que el mito es recreado por especialistas del rito en la tierra (fig. 26).

Al respecto, Rodolfo Sánchez (2012:36) tiene una interesante posición en cuanto al simbolismo de las sogas, señala que éstas tendrían vinculación con el acceso al centro de la Vía Láctea, "al lugar donde se encuentran las puertas de los dos mundos y por donde es posible que seres de poder o intermediarios ingresen para obtener el don de la vida en forma de illas fecundantes o semillas arquetípicas de las especies".

Así como hay campos mayores definidos por las sogas, hay también escenas menores establecidas a través de marcadores simbólicos como la figura de un personaje mítico de frente, con porra, escudo y "corona de tipo estelar" que se encuentra algunas veces magnificado y en un solo caso, aparece en posición felina o supina. Otras veces, sólo aparece como figura estelar con rostro, con puntas agudas o redondeadas, similares a la corona del personaje visto en planta, que por su forma y características, nos sugiere un motivo abreviado del personaje completo y que siempre acompaña al personaje mítico (fig. 27).

Anteriormente se había propuesto (ver Franco y Vilela 2005) que este ser mítico personifica a la estrella Venus o lucero, planeta que aparece como uno de los principales referentes del cosmos y que se encuentra en las escenas de navegación, y precisamente un ejemplo de la figuración de este motivo estelar con puntas redondeadas aparece claramente definida en los relieves de la Huaca Las Balsas de Túcume (ver Narváez 2011: 111). En suma, este ser de tipo estelar, vendría a ser una especie de ordenador del tiempo y del espacio, que seguramente tiene alguna significación especial relacionada al mito, quizás, también relacionado con las pléyades o simplemente con el planeta Venus en una rueda mítico-calendárica. Lo que llama poderosamente la atención es que este personaje con corona no aparece dentro del corpus iconográfico moche, sólo se muestra la corona con puntas redondeadas en un textil de la época 3 del Horizonte Medio de Pachacámac encontrada por Uhle (1903: Fig.5-All Objects: $1 / 2$ N. 8).

Muchas escenas míticas que aparecen en los murales son referentes simbólicos de ritos o ceremonias que aluden a ecosistemas en el que viven los seres vivientes, tanto que estas mismas escenas 


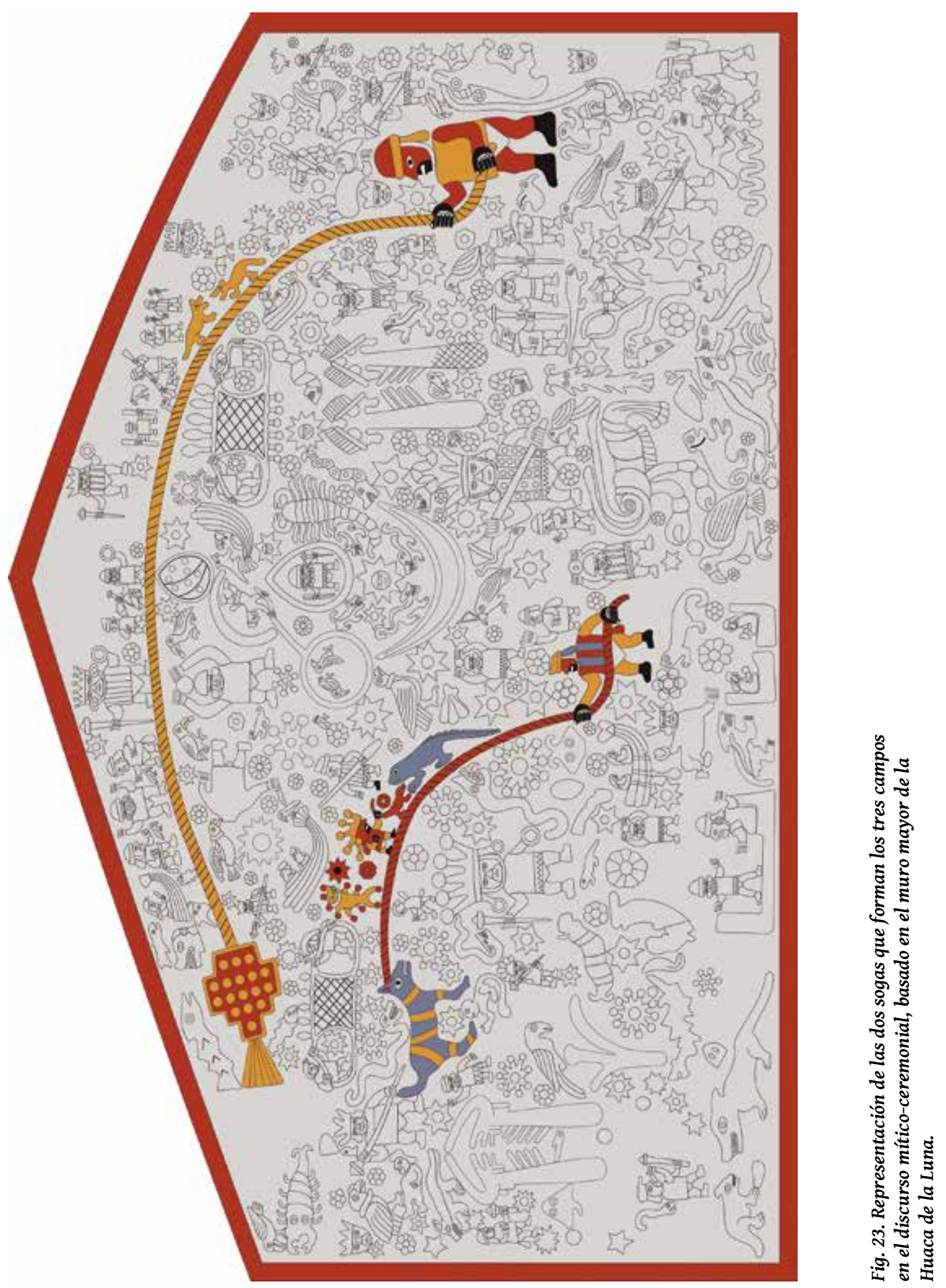



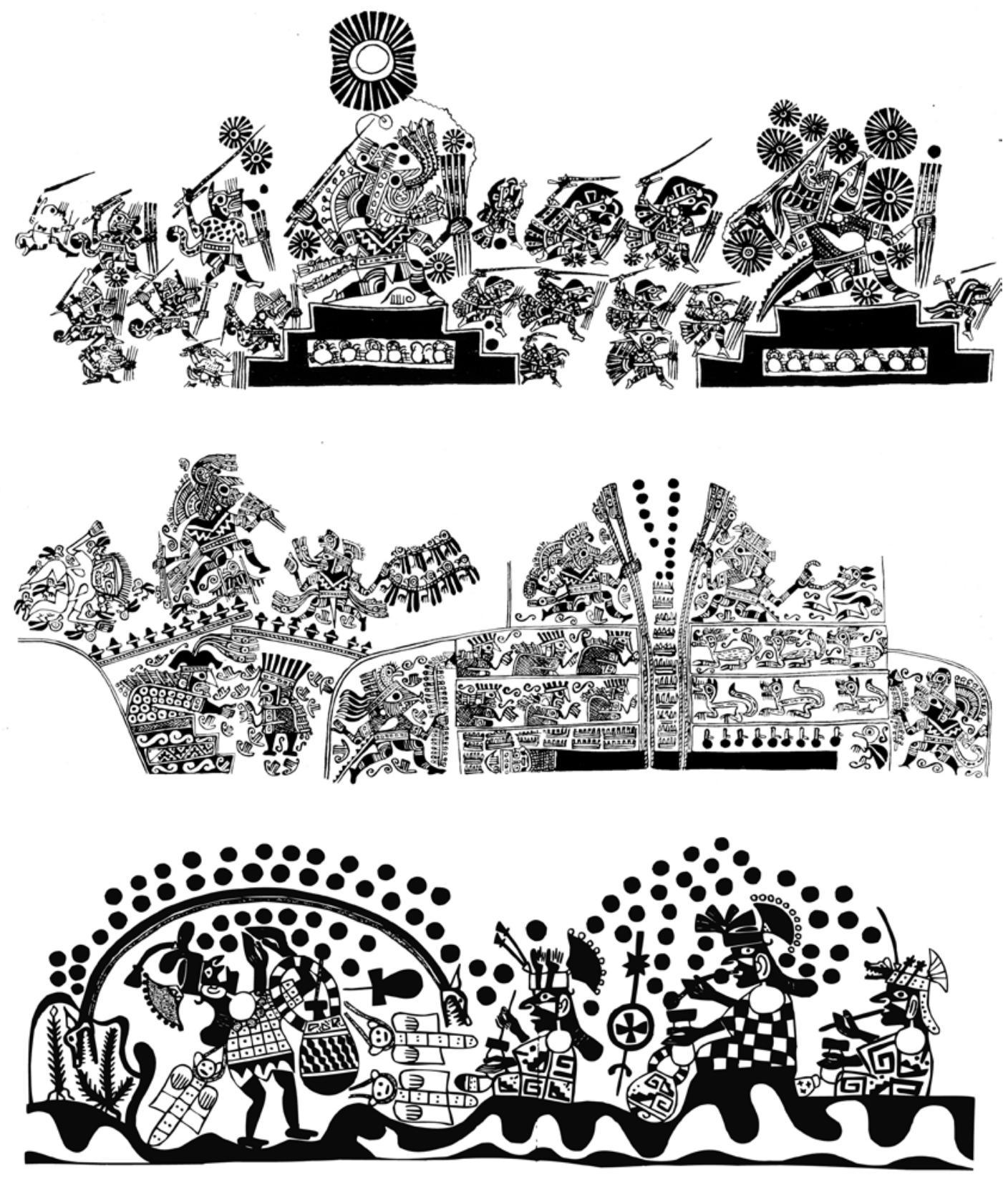

Superior: Fig. 24. Escena de "badminton ceremonial" (Tomado de Donnan 1978).

Medio: Fig. 25. El tema del entierro en la iconografía Moche (Tomado de Donnan y McClelland 1999).

Inferior: Fig. 26. Escena de actividades chamánicas en la iconografía Moche (Tomado de Donnan 1978). 


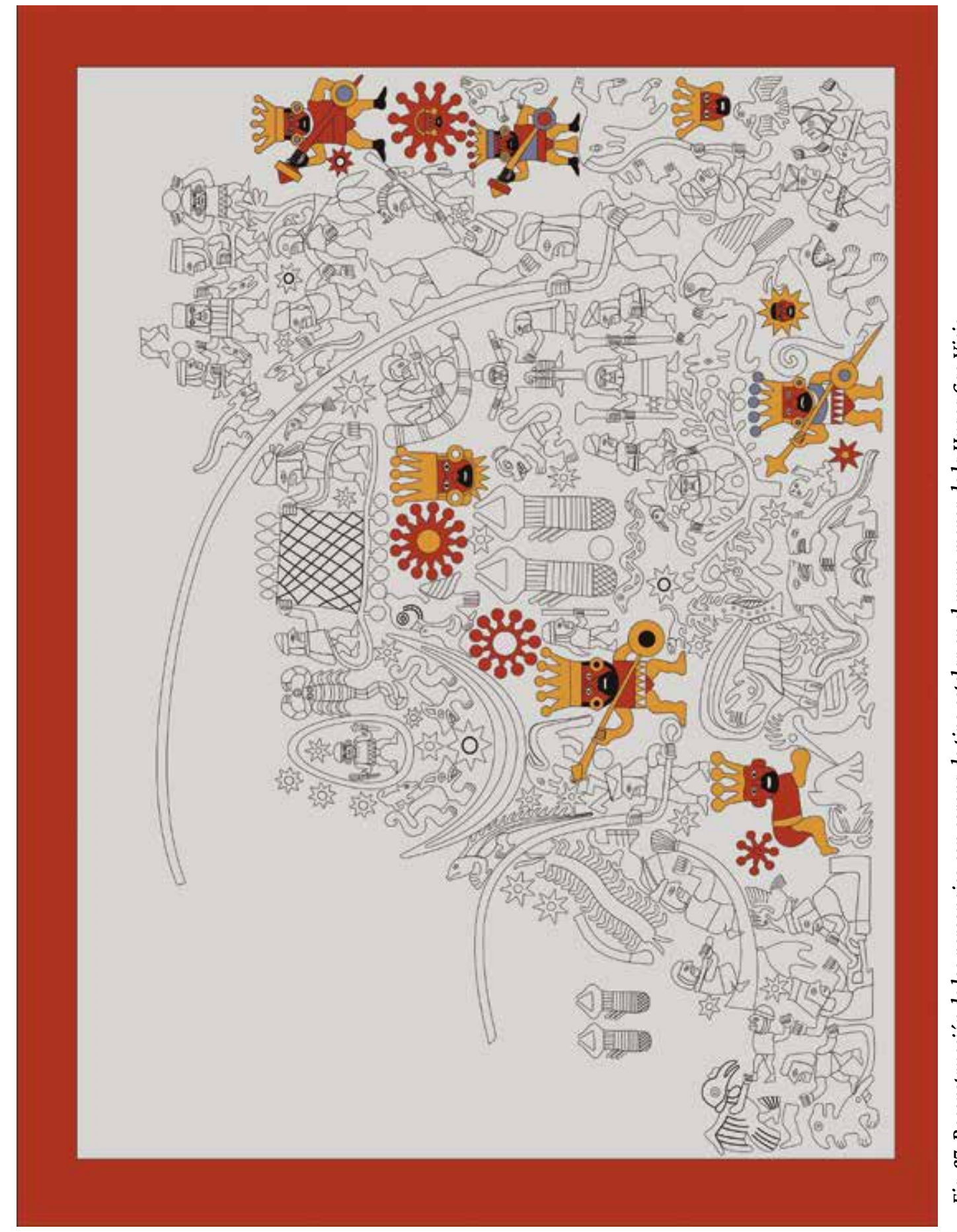

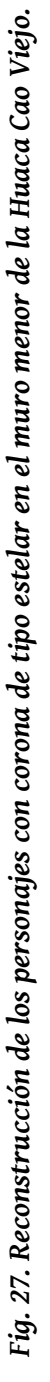


aparecen en un discurso mayor en la iconografía moche, por ejemplo, para tener sólo una idea, la garza (Nycticorax nictycorax hoactli "huaco") que pesca un pez Life en el plano inferior se asocia a un medio de albuferas, totorales y peces.

\section{La Dimensión Estelar del Campo Superior}

Este campo aparentemente tiene una trayectoria de escenas y motivos de abajo hacia arriba, de derecha a izquierda. Como vamos a ver, en el mundo de abajo se inicia con combates rituales, luego vienen ofrendas para los ancestros que moran en el mundo de arriba, acompañado de escenas de suplicio y pasaje de ancestros hasta el encuentro con la divinidad mayor en el mundo de arriba, en el mundo celeste y estelar. Sin embargo, al parecer, las actividades plasmadas son complementarias (fig. 28).

\section{El Combate Ritual: Rito Agrario y de Pasaje}

En el ángulo inferior lateral derecho de los Temas Complejos, vistos con mayor énfasis en los muros mayor de la Huaca de la Luna y mayor y menor de la Huaca Cao Viejo, se tiene una escena de combate a mano limpia entre dos individuos vestidos en forma sencilla, acompañados de una serpiente que repta por el suelo y a veces ataca a uno de los oponentes, así como un felino macho que ataca a uno de los combatientes o quizás, así como la serpiente, trasmiten simbólicamente su poder de energía fertilizadora para una mejor culminación del combate (fig. 29).En algunos casos, el personaje de la derecha (visto en los muros mayores de Cao Viejo y La Luna) es el vencedor, al coger de los cabellos o tocado a su oponente, presto a asestarle un golpe con una piedra o chungo que lleva en la mano. La escena es acompañada de un lucero y un águila costera con las alas abiertas detenida en el aire, y también está la presencia del mítico personaje con corona de tipo estelar. Esta escena tiene analogía con una representación de pintura mural encontrada en la Huaca Pañamarca del valle de Nepeña, donde uno de los combatientes también le coge de los cabellos a su oponente (ver Bonavia 1985: 32) (Fig. 30).

Este enfrentamiento entre dos jóvenes guerreros, revela quizás un rito de iniciación vinculado con el pasaje a una etapa de maduración, muy parecido a la lucha que se practicaba en la época Inca. De acuerdo al análisis de Hocquenghem $(1987: 121,122)$, con relación a este tipo de combate en la iconografía Moche, se trataría de enfrentamientos asociados a ritos agrícolas y de pasaje que simbolizan la cercanía de la cosecha. El felino, el águila y la serpiente que participan en esta escena, son animales sagrados o agregados que sirven para incentivar o propiciar la fertilidad del mundo doméstico. El águila (Geranoaetus melanoleucus o "águila de pecho negro") a menudo se encuentra asociado a escenas de combate, otras veces se expresa como un ave guerrera con escudo y porra (fig.31); aparece también volando sobre escenas de combate, así como aparece en el brazalete del Señor de Sipán. Su carácter sagrado es inminente, tanto que en la parte alta de la Huaca Cao Viejo, cerca del hallazgo del ídolo, se descubrió la cabeza de esta ave tallada en madera y que estaba originalmente revestido con plumas naturales y que formó parte de una escultura mayor (Franco et. al. 2001b: 161, Foto 24) (fig. 32).

\section{LAS OFRENDAS A LOS ANCESTROS}

En la sección inferior lateral derecho de los Temas Complejos, vistos con mayor énfasis en los muros mayor de la Huaca de la Luna y menor de la Huaca Cao Viejo, aparece un personaje con bulto sobre la espalda, que coge una soga atada a los cuernos de un venado (Odocoileus virginianus), y a un costado se registra a un felino en posición de ataque. El individuo con el venado se dirigen al ancestro mítico con porra, escudo y corona de tipo estelar. Seguramente, el bulto que lleva sobre la espalda 
contiene ofrendas, quizás semillas para los ancestros míticos. Estas ofrendas, a mi modo de ver, indican la entrega del sustento vegetal y animal a los ancestros en que habitan en el plano estelar y que se encargan de perpetuar y asegurar la subsistencia humana en el mundo terrenal (ver Hocquenghem 1987:124-126,127) (figs.33-34). La contraparte de este rito en el mundo marino, serían los ritos de pasaje en la barca mítica transportando ofrendas humanas y objetos para los ancestros (fig. 35).

En la proximidad de la escena, en el marco del mural pintado de rojo (sólo visto en el muro menor de Cao), aparece un graffiti (Franco et. al 2001: fig. 7) con la escena de un guerrero de perfil con casco, porra y dardo, acompañado de un felino (Felis concolor) que aparece en posición de ataque. La presencia de un guerrero en graffiti puede significar que el venado pudo provenir de una caza ritual, donde a menudo en la iconografía Moche se observan a personajes bien ataviados, de gran jerarquía, con implementos y accesorios (ver Donnan 1979).

El venado ha sido un animal muy importante en los rituales Moche. En el "tema del entierro" se observa al personaje iguana con una bolsa sobre el pecho, jala a un venado para sacrificarlo. Aparece también en las escenas de sacrificio de montaña, donde los venados son victimados y cargados por personajes que son ofrecidos a la divinidad de la montaña (Hocquenghem 1987, fig. 185) (fig. 36). Otras veces el venado es sacrificado en rituales funerarios. Se le aprecia capturado en la escena de los objetos rebeldes. Se encuentra en la escena de bádminton ceremonial; aparece tocando tamboriles en una danza en la que participa un PACS (personaje antropomorfo de cinturón de serpientes) con otros personajes; lucha como guerrero con un pallar antropomorfo; y toma el aspecto mitológico de un ser fabuloso ciervo-serpiente-jaguar. Entonces, el simbolismo del venado nos acerca al mundo salvaje, no domesticado, que ha trascendido hasta nuestra época y que forma parte, incluso, de la naturaleza mágica de los chamanes norteños (Sharon, 1980).

Hocquenghem (1987: 130-131) compara estas escenas Moche con los ritos de los incas, dice que las ofrendas y sacrificios eran confiados "veinte días después del combate del camay que se lleva a cabo el día de la luna nueva, después del solsticio de verano". Según la misma investigadora, recogiendo la información de Isbell (1976: 53-54) y Mariscotti (1978: 34, 103), señala también que: "los indígenas consideran los días que preceden al equinoccio de la estación húmeda como propicios a las ofrendas o pagos a los ancestros, para obtener la multiplicación de sus bienes y dicen que la tierra se abre en este período del año". En otros casos, las ofrendas se dirigen para el ancestro F mostrando los bultos con los objetos (Golte 1994: 61).En consecuencia, hay la posibilidad de entender que después del combate ritual hay una etapa de comunión de la sociedad con los ancestros míticos y divinidades.

\section{Los Ritos de Expiación y de Pasaje}

Este episodio tiene varias escenas muy claras en el mural mayor de la Huaca de la Luna, desde actos de expiación asociado a un ecosistema húmedo de flora y fauna de albuferas (flor de loto, flores acuáticas flotantes, batracios, aves), rodeadas de figuras estelares. En el caso del mural menor de Huaca Cao, las escenas se abrevian, mostrando con claridad las escenas de expiación y de pasaje.

En principio, se trata de un personaje con trusa que ataca a un individuo tendido en el suelo, que en el mural de Huaca de la Luna este mismo personaje tiene al parecer rasgos cadavéricos acompañado de estrellas, que hace recordar a la escena del gallinazo cogiendo de los pies a un cadáver en el campo estelar de la dimensión o campo inferior del mural menor de Huaca Cao Viejo. Estos ritos de expiación o sacrificio tendría el sentido de limpiar el pecado del pueblo frente a episodios negativos que serían simbólicamente purificados. que serian simbólicamente purificados. 
En el muro menor de Huaca Cao Viejo, aparece un personaje alicaído de perfil con rasgos cadavéricos con el brazo flácido, sostenido por otro personaje con tocado que lo conduce en medio de una estrella. Uno de los atributos importantes del personaje alicaído o ancestro divino, aparte de sus rasgos cadavéricos, es que lleva sobre su hombro un instrumento de labranza con una planta ramificada de yuca. Aquí se entiende la relación del ancestro con la reproducción de los alimentos, en este caso particular, de la yuca (fig. 37).

El ancestro mítico es llevado por un hombre que va en dirección hacia un zorro feroz que sube y se enfrenta a otro similar que baja y que se encuentran sobre la soga. Esta escena, en mi entender, simboliza el rito mítico de entrada de la divinidad fertilizadora de las plantas al otro mundo, conducido por un personaje acólito y encabezado por un zorro que lucha o se enfrenta a otro zorro. Estos animales son considerados como guías para ingresar al mundo paralelo de los ancestros en el plano estelar. El zorro aparece en los mitos de Huarochirí como guía para asegurar la productividad de la tierra propiciada por Pariacaca y su presencia siempre está vinculada al discurso de las divinidades.

En la parte superior de la escena anterior, en el muro menor de Cao Viejo, se muestra la representación de frente del "personaje antropomorfo de cinturón de serpientes" (PACS) o divinidad mayor o suprema, asistido por dos personajes laterales o "sujetadores" (Castillo 1989: 141-144), considerado como "el mellizo terrestre" (Makowski 1996:61), que aparece junto a otro personaje de frente que levanta los brazos cogiendo un disco. En otras representaciones este ser aparece en un estado de mareamiento y es sujetado por gallinazos (ver Larco 2001:339, fig. 357; 340, fig. 358) o también por iguanas antropomorfas (figs.38-40). ¿Es acaso una metáfora de la divinidad lunar en su proceso de cambios vinculado con el sistema agrícola de siembra y cosecha?.

Hocquenghem (1987: 99, 138; figs. 133, 141, 144-146) indica que los bailes de muertos, actos sexuales que no conducen a la fertilización deberían "corresponder a las ceremonias relacionadas con la despedida de los difuntos después del equinoccio de la estación húmeda... cuando los días comienzan a acortarse, el frío a hacerse sentir, las pléyades van desapareciendo, el sol pierde fuerzas".

En otras versiones, este ser mítico (PACS) se une con mujeres, participa en los suplicios, clama a los difuntos, atraviesa el océano, es acompañado por el perro y la iguana, entra en el mundo de los muertos para luego renacer y cumplir las actividades del mundo doméstico (Hocquenghem 1987: 184-185) (Donnan McClelland 199: 127) (fig. 41). Estas imágenes en conjunto sustituyen un episodio relacionado con el ancestro fertilizador y el pasaje de la vida al mundo de los ancestros. ¿Este episodio tiene, quizás, relación con el calendario agrícola de los Moche?

En el caso de la parte superior del mural mayor de la Huaca de la luna, a diferencia del mural menor de Cao Viejo, se observa una narración de escenas y motivos sin orden de lectura, como por ejemplo, existen dos actos de suplicio o expiación separados, que están próximos a otra escena similar de un personaje posiblemente amarrado a un poste, que tendría alguna semejanza con el personaje que aparece supliciado y devorado por gallinazos en la iconografía moche. La trayectoria de estas escenas y motivos es aparentemente hacia el plano superior, donde se encuentra la divinidad suprema de los Moche, lamentablemente perdida en el mural mayor de Huaca de la Luna y totalmente ausente en los dos murales de Cao Viejo.

Hacia la izquierda, que podría tratarse de otro plano, pero en el mismo nivel, vemos magnificado a un personaje de frente con una porra en la mano rodeado de luceros, asociado a una escena de pasaje de un ser que aparece con las manos levantadas y sostenido por dos personajes laterales "sujetadores" y una escena de navegación asociado a peces, entre estos el pez raya tan importante en el mundo marino y asociado a los orígenes de los moche. Este conjunto de imágenes, en este plano, está posi- 


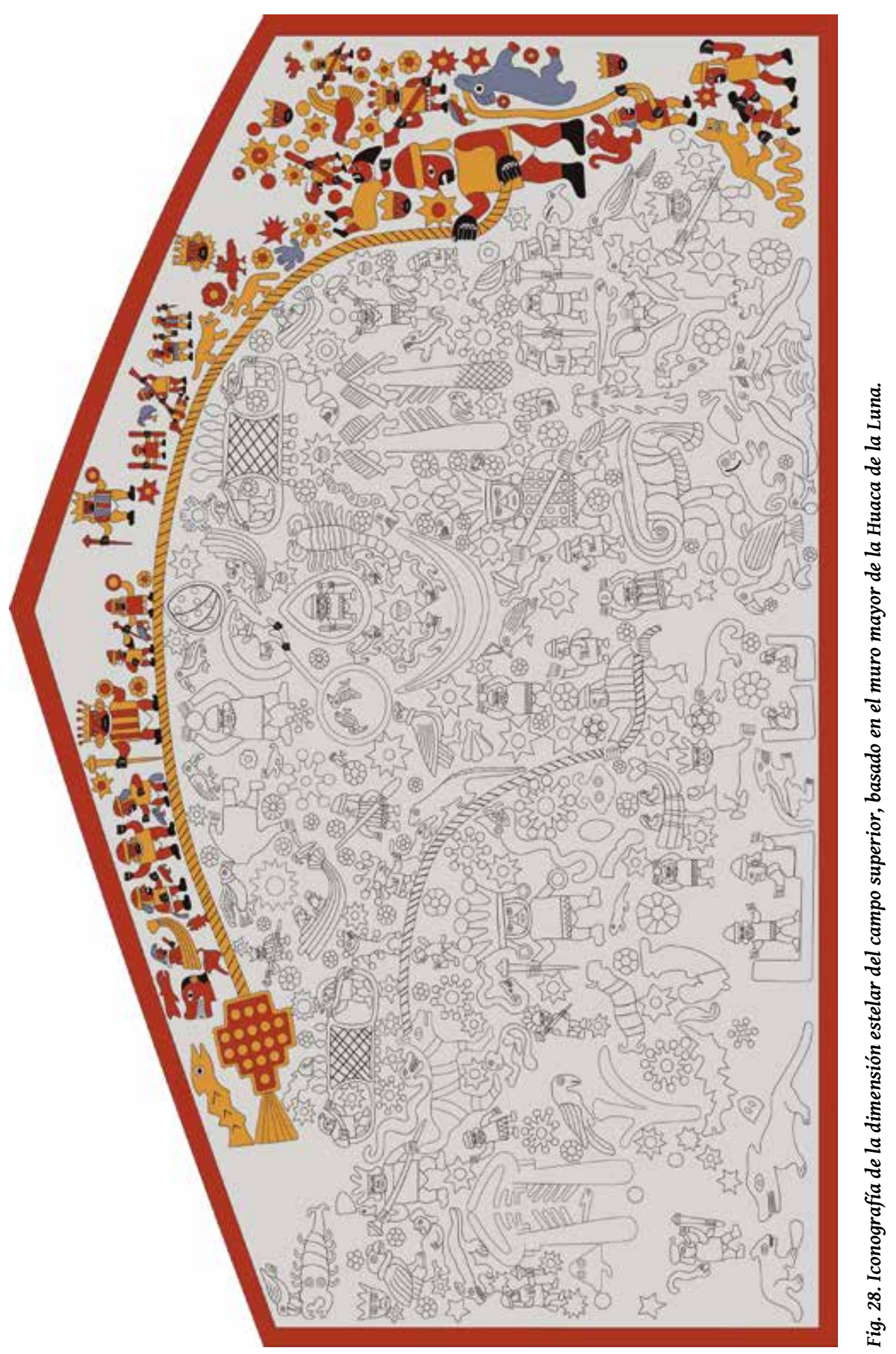




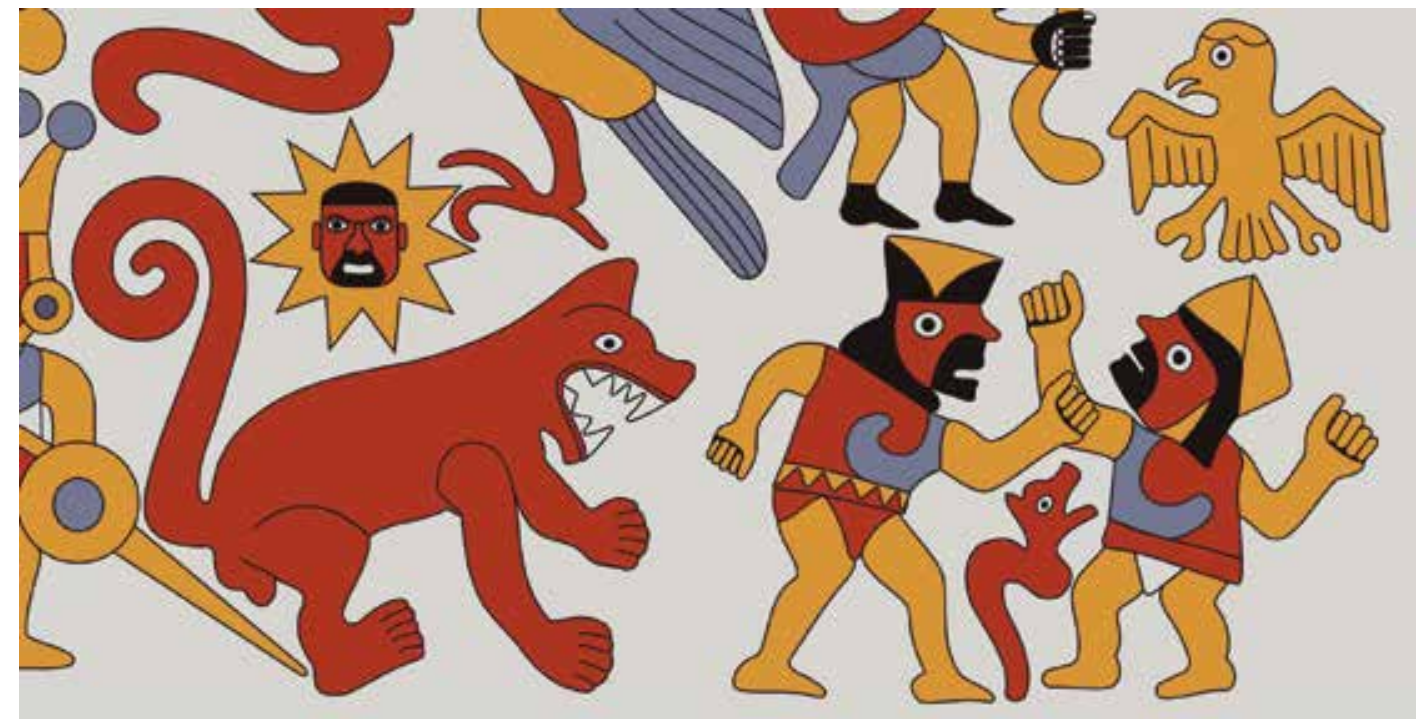

Fig. 29. Reconstrucción de la escena de combate en el Tema Complejo 1, basado en el muro menor de la Huaca Cao Viejo.

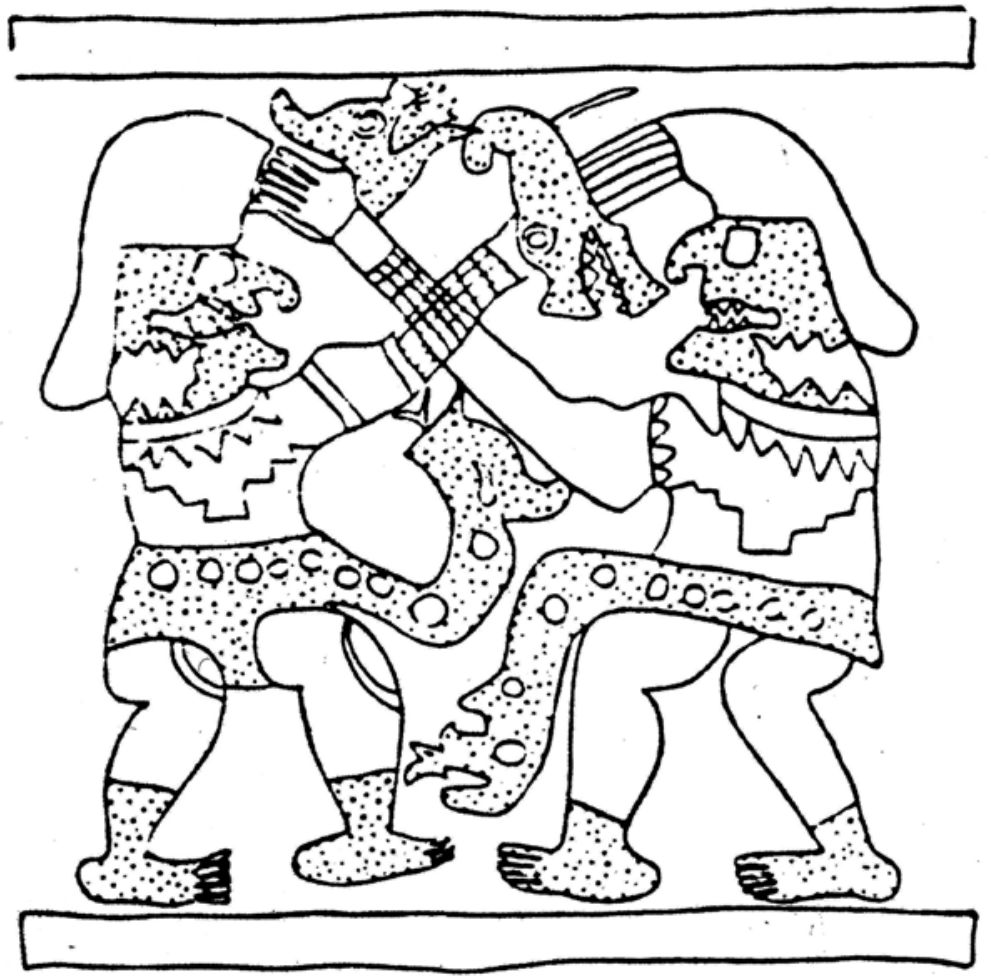

Fig. 30. Escena de combate ritual en la Huaca de Pañamarca (tomado de Bonavia 1985). 


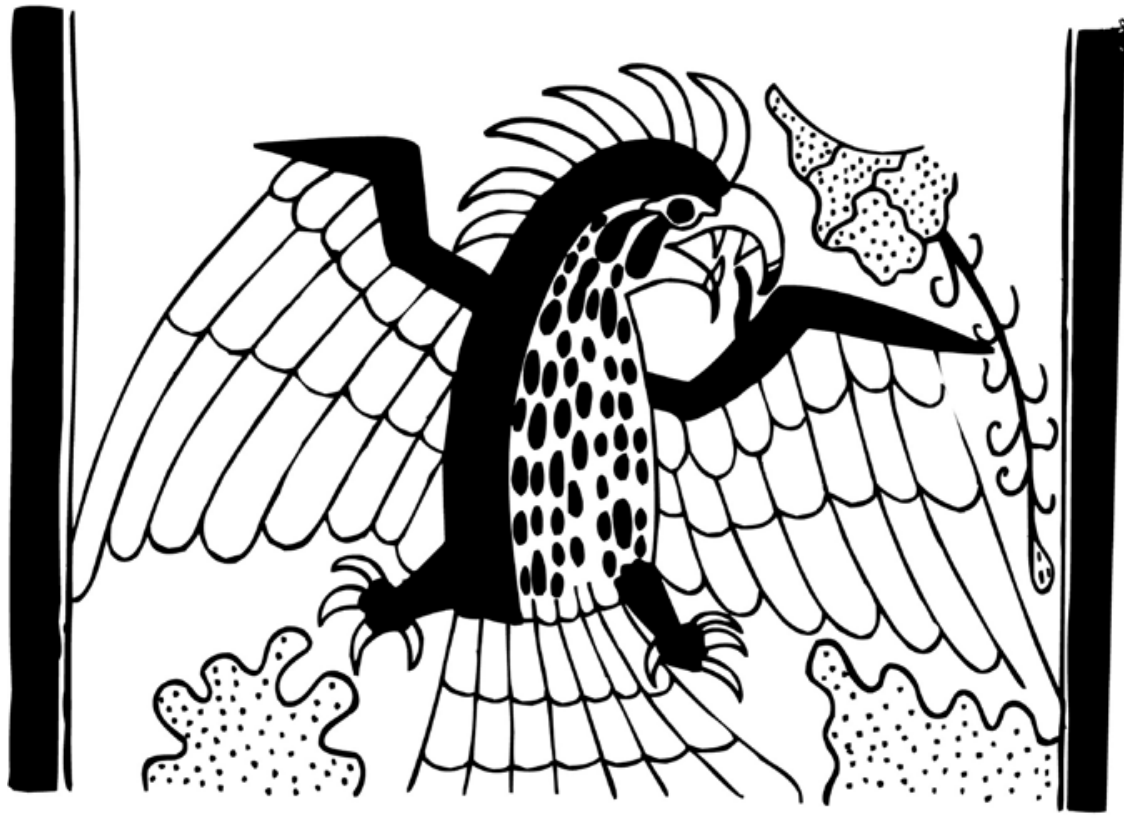

Fig. 31. Águila costeña de pecho negro en pleno vuelo (Tomado de Kutscher 1983).

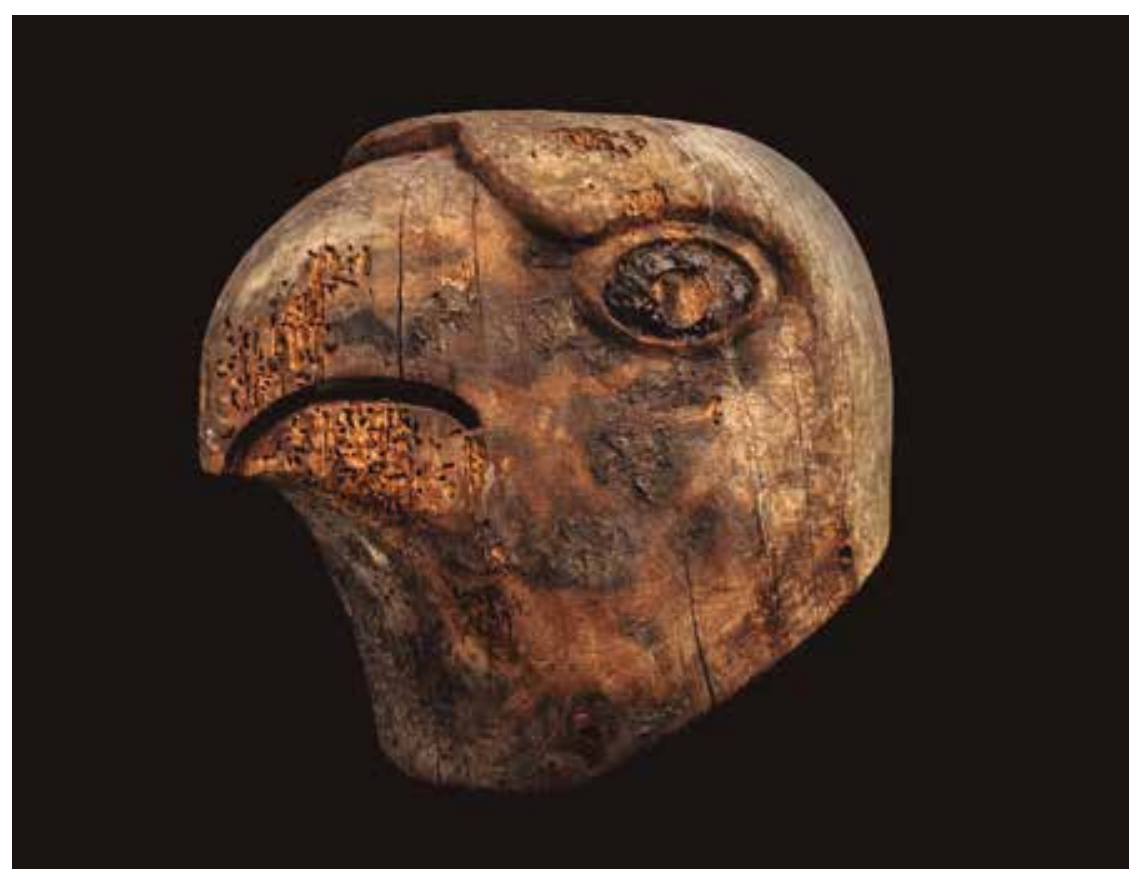

Fig. 32. Cabeza escultórica de águila trabajada en madera. Colección Museo Cao. 

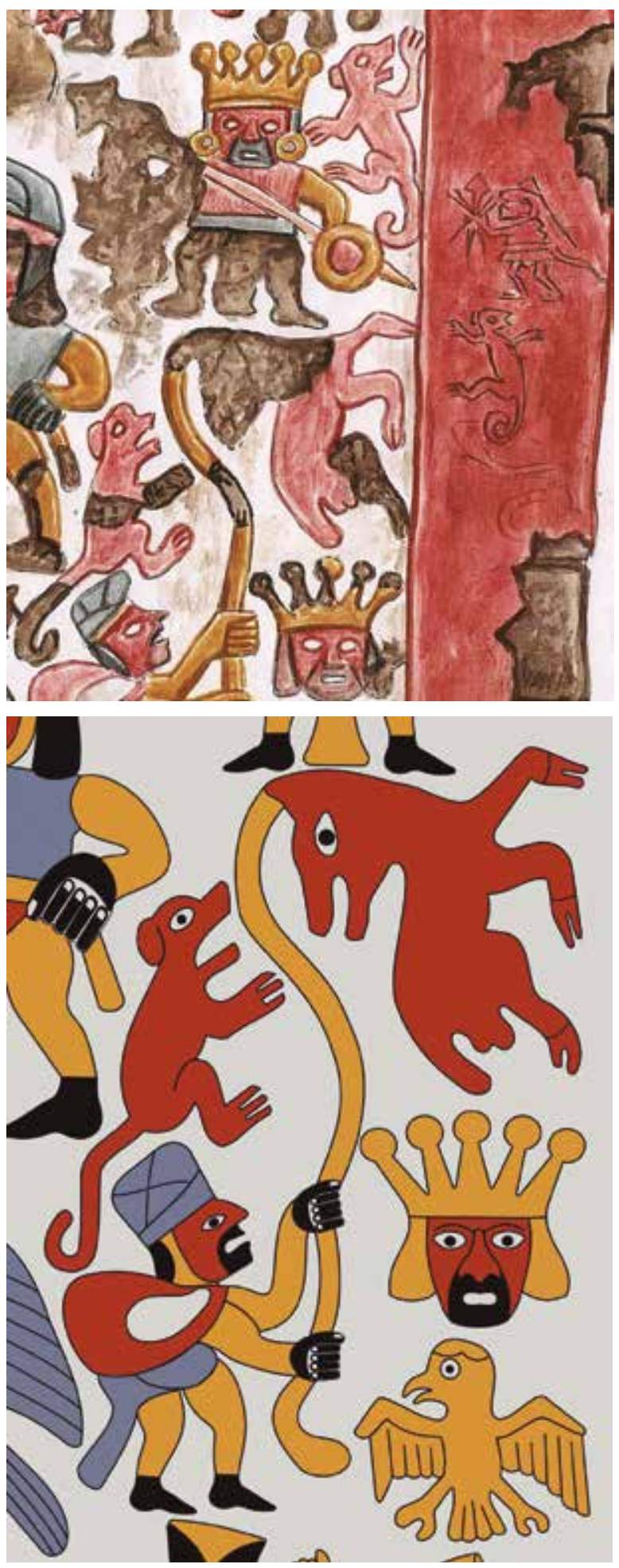

Fig. 33. Ilustración del estado actual de la ubicación de los motivos en la parte inferior derecha del muro menor de la Huaca Cao Viejo.

Fig. 34. Reconstrucción de la escena de entrega de ofrenda al ancestro mítico, basado en el muro menor de la Huaca Cao Viejo (ilustración de Luis De La Vega). 

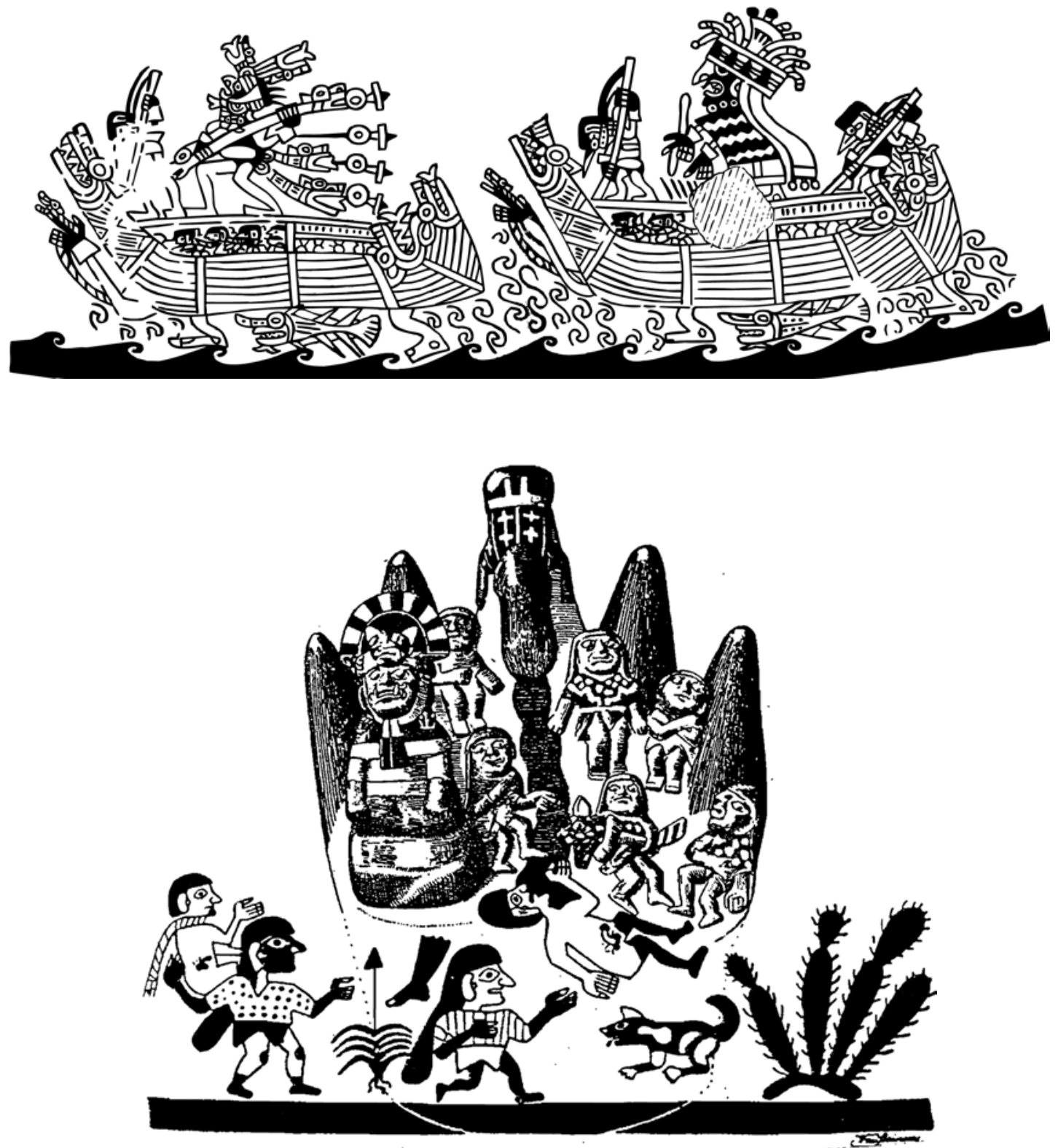

Superior: Fig. 35. Escena de navegación en la iconografía Moche. Transporte de prisioneros a las islas (Tomado de Donnan y McClelland 1999).reemplazar figura

Inferior: Fig. 36. Escena de sacrificio en montaña (Tomado de Donnan 1978). 

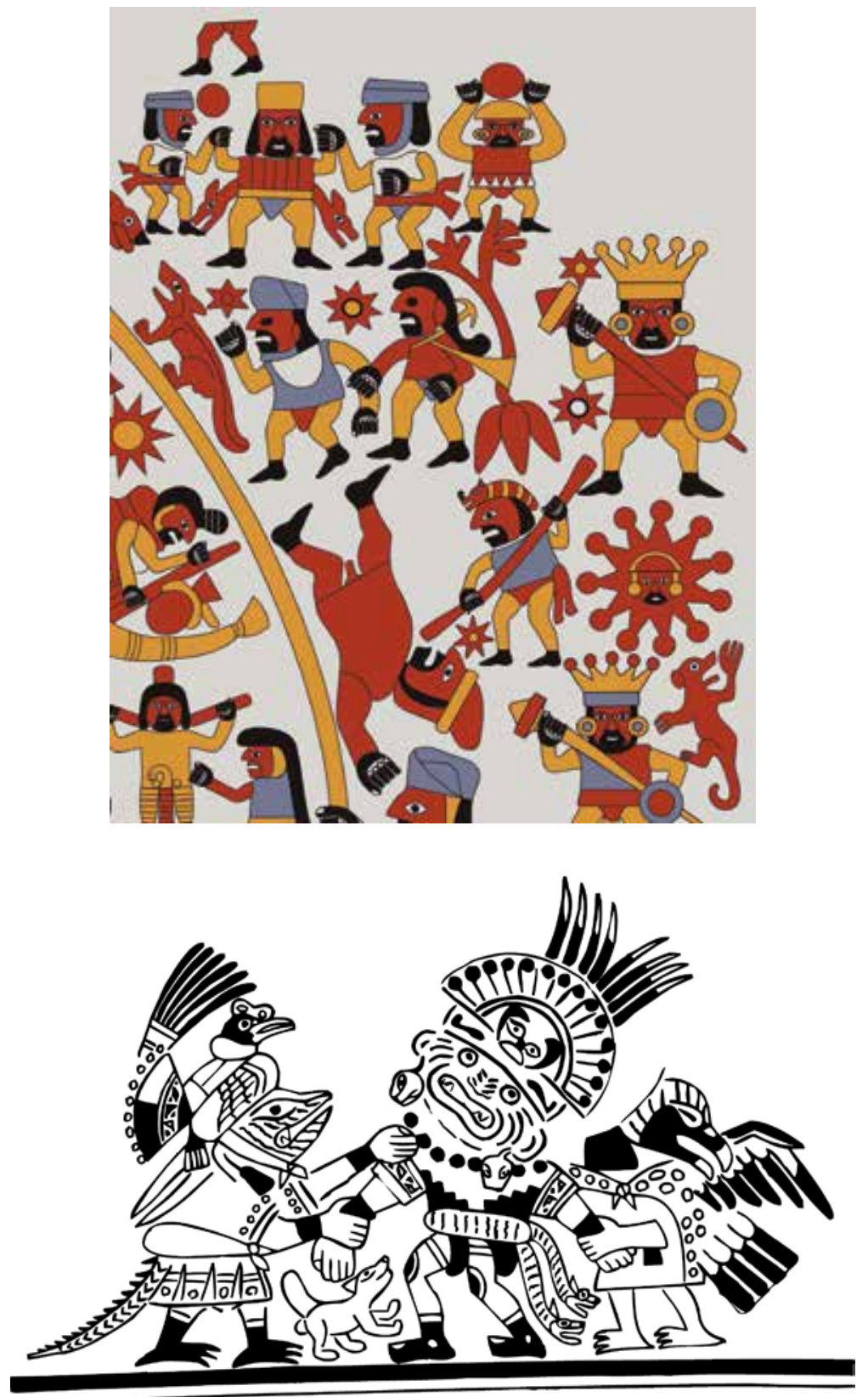

Superior: Fig. 37. Reconstrucción de la escena de ritos de expiación y de pasaje del ancestro mítico, basado en el muro menor de la Huaca Cao Viejo (ilustración de Luis De La Vega).

Inferior: Fig. 38. Divinidad principal en una actitud de pasaje asistido por una iguana y un buitre (Tomado de Hocquenghem 1987). 

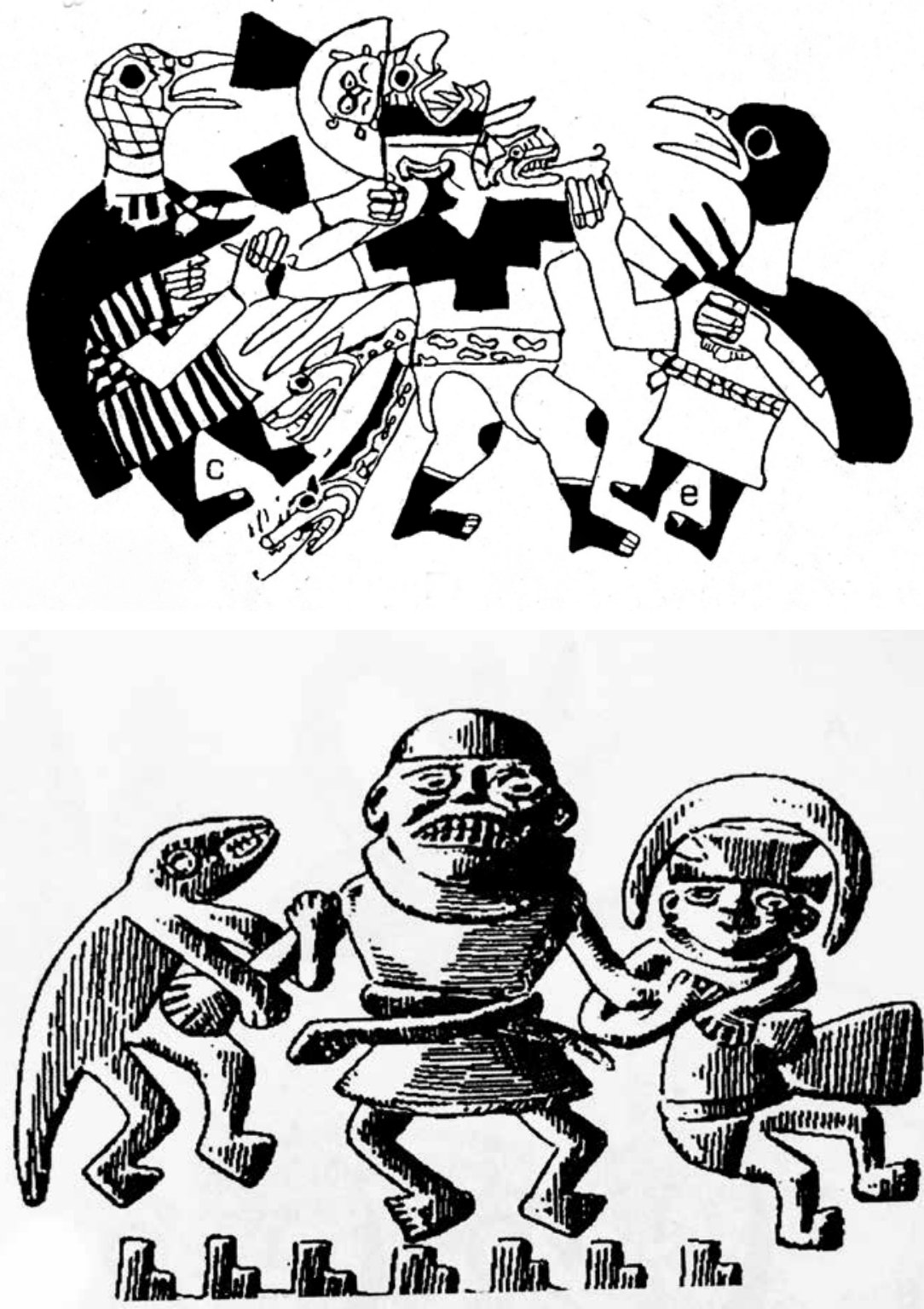

Superior Fig. 39. Divinidad principal asistido por gallinazos (Tomado de Castillo 1989).

Fig. 40. Ancestro cadavérico asistido por una iguana y un personaje lunar (tomado de Kutscher 1954). 


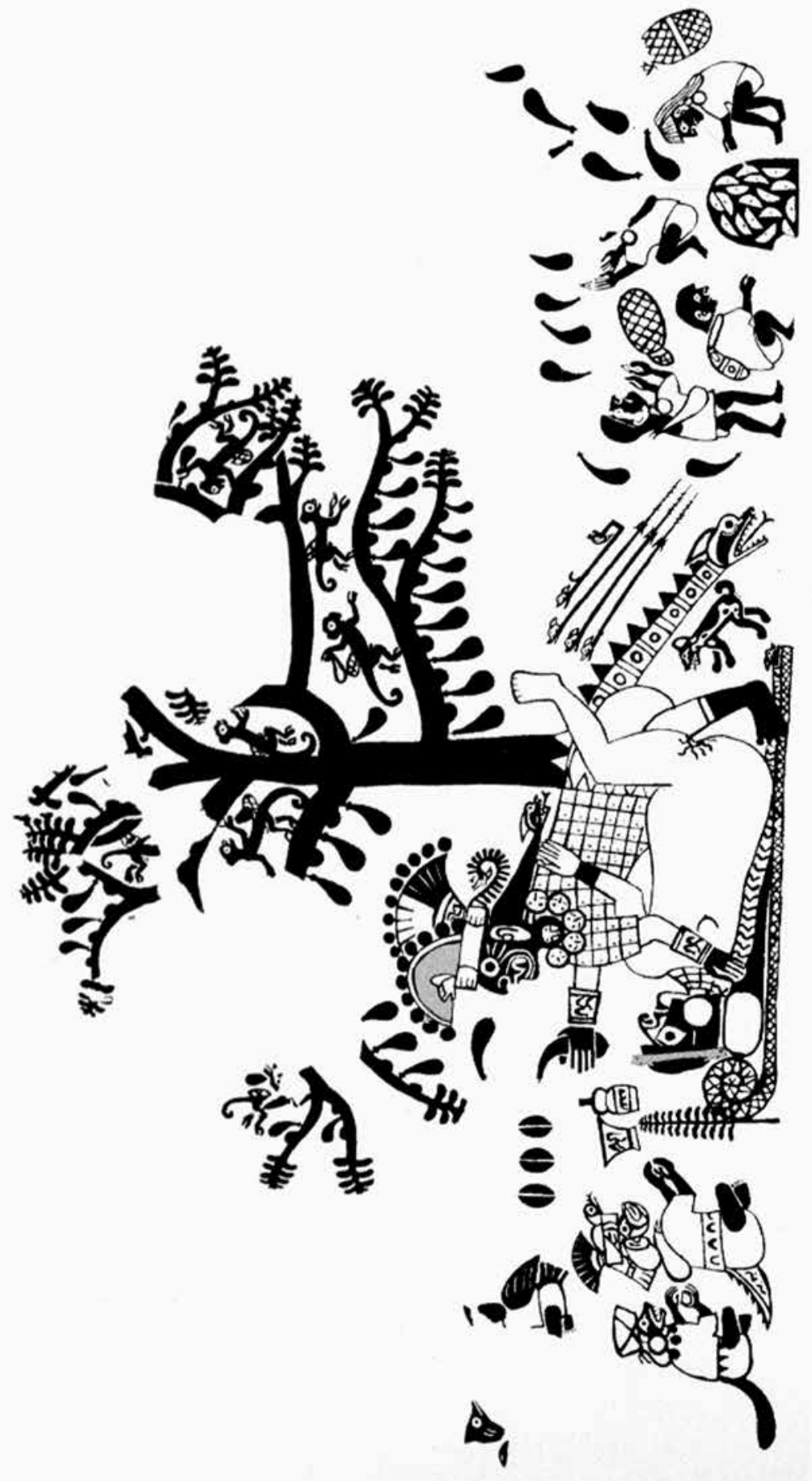


blemente asociado al mundo marino y sería el complemento del mundo terrestre que se encuentra al otro lado. Además, tiene una proximidad a la figura en forma de chakana o estelar. En efecto, se podría indicar que a partir de la figura mayor y central se cumplen los ciclos marinos (izquierda) y terrestre (derecha) que en conjunto forman una dualidad cósmica desde los orígenes.

\section{La Dimension Estelar del Campo Central o Mito de Creación}

Este campo tiene una composición de imágenes en el plano superior con escenas asociativas de dimensión cosmogónica, cosmológica, astral y lunar, asociados a escenas de expiación, badmington, pesca, navegación, donde algunas escenas tienen duplicidad hacia ambos lados de las escenas cosmogónicas (derecha e izquierda), claramente asociados al mundo estelar, lunar y marino. Asimismo, se destaca en la parte inferior, escenas de divinidades lunares, divinidades fertilizadoras, tanto en el mundo marino como en el mundo terrestre. No hay definitivamente una estructura ordenada, pero si, quizás, hay una fuerte relación narrativa vertical entre el numen, el huevo cósmico y la Luna, con sus respectivas lecturas simbólicas, lo que hace suponer que el mensaje mítico cosmogónico y cosmológico es complementario (fig. 42).

\section{El Numen, los Orígenes y las Pléyades}

Este conjunto de imágenes ocupa una posición central-superior de toda la composición mural, que lo hace sumamente importante con relación al resto de representaciones, por tratarse del fundamento principal de los orígenes míticos (creación) y todos los seres cósmicos que acompañan en este proceso.

En el caso específico del muro mayor de la Huaca de la Luna, perdido totalmente en los muros mayor y menor de la Huaca Cao Viejo, aparece en la parte superior una figura ovalada de color amarillo, definida con doble línea y con pequeños círculos distribuidos en su interior, similares a los que se encuentran al interior de la figura en forma de Chakana. Esta imagen se encuentra flanqueada por dos figuras estelares, tal vez se tratan de los dos luceros (Venus del amanecer y del atardecer) muy parecidos a los luceros que acompañan a la luna en la parte inferior. Por la ubicación central en el que se encuentra, se trataría de un símbolo inconcebible, de una fuente de poder, con equivalencia a los principios del mundo, la totalidad y la unidad de todas las dimensiones espaciales y temporales, es decir un Numen.

De la base de la figura ovalada, se desprende otra escena más compleja de un personaje mítico, echado, cubierto al parecer por una luna nueva casi parada- que tiene mucho que ver con la concepción humana que se podría relacionar con ciertas creencias sumerias- que coge una especie de liana que culmina en un círculo con motivos no identificados, equivalente quizás a las manchas lunares o probablemente especies marinas y terrestres en el interior. Este personaje mítico, por la postura que tiene, al parecer está flotando en el espacio y está sujeto a los cambios lunares (luna nueva y llena) y participa simbólicamente en un episodio mágico de creación de las especies. Alfredo Narváez (2011: 121) y Rodolfo Sánchez (2012: 54), consideran que este episodio tiene relación con la procreación de los seres marinos, y particularmente este último investigador, ha indicado que este simbolismo tendría relación con los cambios lunares y su influjo en los procesos metabólicos de plantas y animales, $\mathrm{y}$, por consiguiente, en la configuración de ciertos ritmos biológicos significativos.

Pero, dentro del mismo contexto, hay otras escenas que merecen describirlas, porque guardan estrecha relación con este sistema narrativo de creación. Está claro, que a partir de las escenas cen- 
trales que se mantienen en posición vertical, de arriba hacia abajo (figura ovalada, escena de creación, figura ovoide o huevo cósmico, la luna en creciente), se dividen en dos áreas: Izquierda y derecha, de relaciones iconográficas con ciertas metáforas (mitos) del mundo celeste y su asociación con la creación de las subsistencias.

Hacía el lado derecho de la figura ovalada, se registra una araña marina (quizás un cangrejo), una embarcación o caballito de totora con su conductor, acompañado de un felino que se dirige hacia un lucero. Junto se observa una escena de pesca y otra escena más pequeña de navegación-acompañadas de luceros- con un personaje sobre un caballito de totora (ver mural pequeño de Cao Viejo) que lleva su media caña o remo, una taleguilla sobre la espalda y una vasija de cerámica con una soguilla amarrada al cuello.

La forma de la red grande, con sus flotadores y pesas amarradas en la parte superior e inferior, se asemeja a un chinchorro (red grande cogida por más de diez hombres), simbólicamente sostenida por dos personajes, instrumento reticulado valioso que sirve para la pesca de orilla o mar afuera cuando hay bonanza marina. Estas escenas, no cabe duda, son metáforas que aluden a seres luminares benefactores de la producción marina, enmarcadas dentro del mito cosmogónico relacionadas con la aparición de las pléyades como marcadores del tiempo.

Hacía el lado izquierdo de la figura ovalada (muro mayor de la Huaca de la Luna), encontramos la figura de un ser de frente que levanta con las manos un disco y es acompañado, hacia ambos lados, por dos gallinazos o buitres. A un costado, aparece, al parecer, el mismo personaje echado, cuya cabeza ha sido devorado por un gallinazo. Estas dos escenas, están, además, rodeadas de figuras estelares y flores de loto, estas últimas a los costados de los hombros. Asimismo, la secuencia, sin orden, se asocia a un personaje con estólica y a una embarcación o caballito de totora con dos personajes y un lucero como guía, y otra escena de pesca más pequeña, equivalente al chinchorro del lado opuesto, asociado a otros seres marinos y figuras estelares.

Aunque la lectura no podría ser correcta, siempre con ciertas reservas, se puede plantear una hipótesis que en el contexto descrito hay una correlación narrativa en cuanto que las dos primeras escenas señaladas (personaje con disco y sin cabeza), y las otras descritas a continuación, tienen posiblemente relación con una metáfora que hace referencia a las fases lunares, cuando este satélite nace y luego se pierde en el firmamento y las consecuencias que éstas traen para la estabilidad de la producción agrícola y marina.

Una gran posibilidad es que este mito ha sido expresado por los Moche en sus artículos ceremoniales. Se tiene por ejemplo una nariguera metálica procedente del sitio de Loma Negra en Piura, donde aparece la cabeza de la divinidad principal picoteado por dos gallinazos o buitres. Recordemos también la presencia de la divinidad del mundo paralelo acompañado de dos cóndores-aves del espacio celeste-que aparece en el recinto-mausoleo de la Señora de Cao y en sus narigueras (Franco 2008) (fig. 43).

¿Podrá ser posible una correlación entre estas representaciones con la referencia del cronista Calancha, cuando señala la presencia de una constelación llamada "pata" adorada por los pobladores de Pacasmayo, donde se hace mención que una estrella es devorada por buitres? (Calancha (197678 [1638]: Lib. III, Cap. II, p. 1243). Estas referencias pueden ayudar a comprender el simbolismo del mundo cosmogónico Moche. 


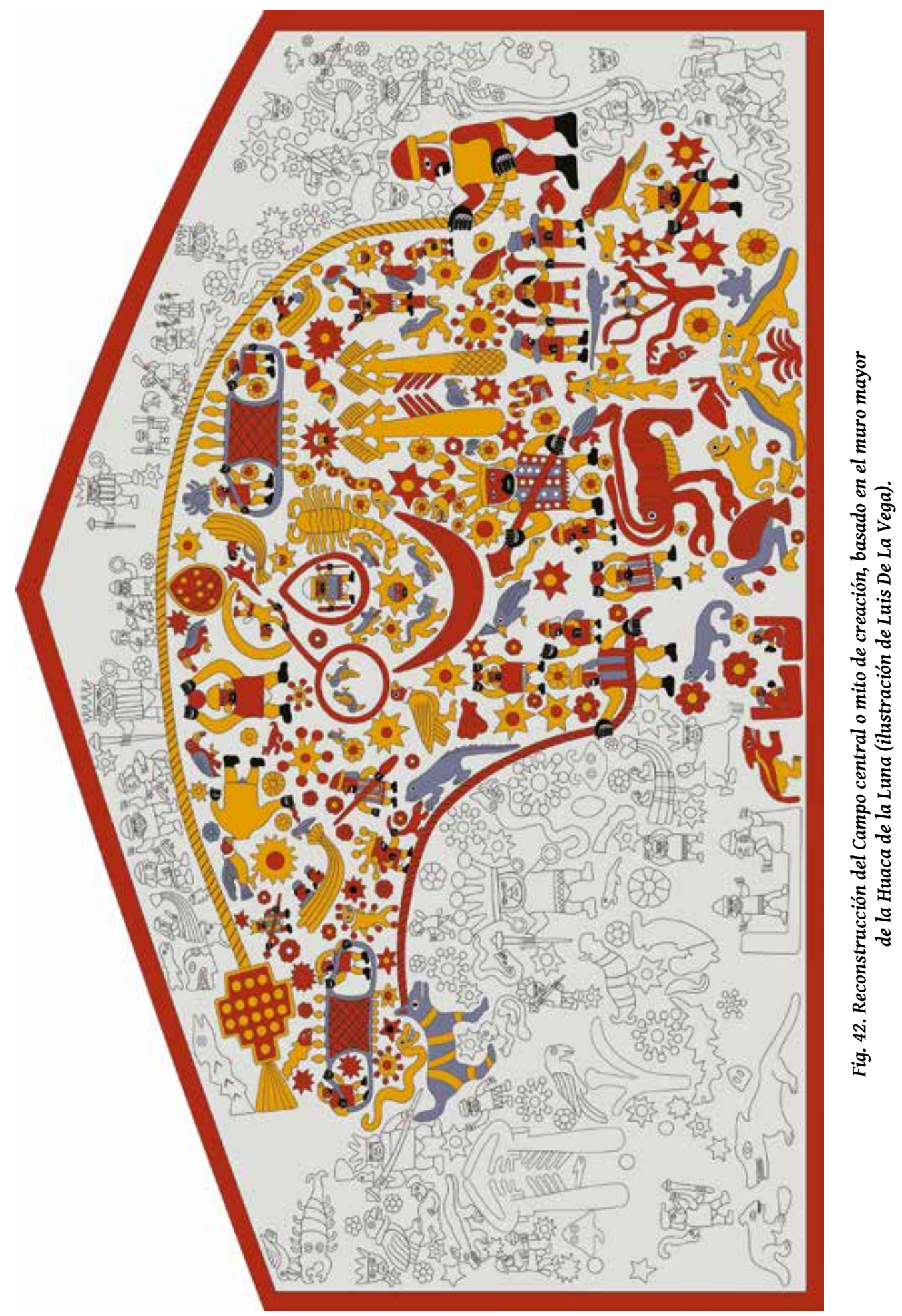




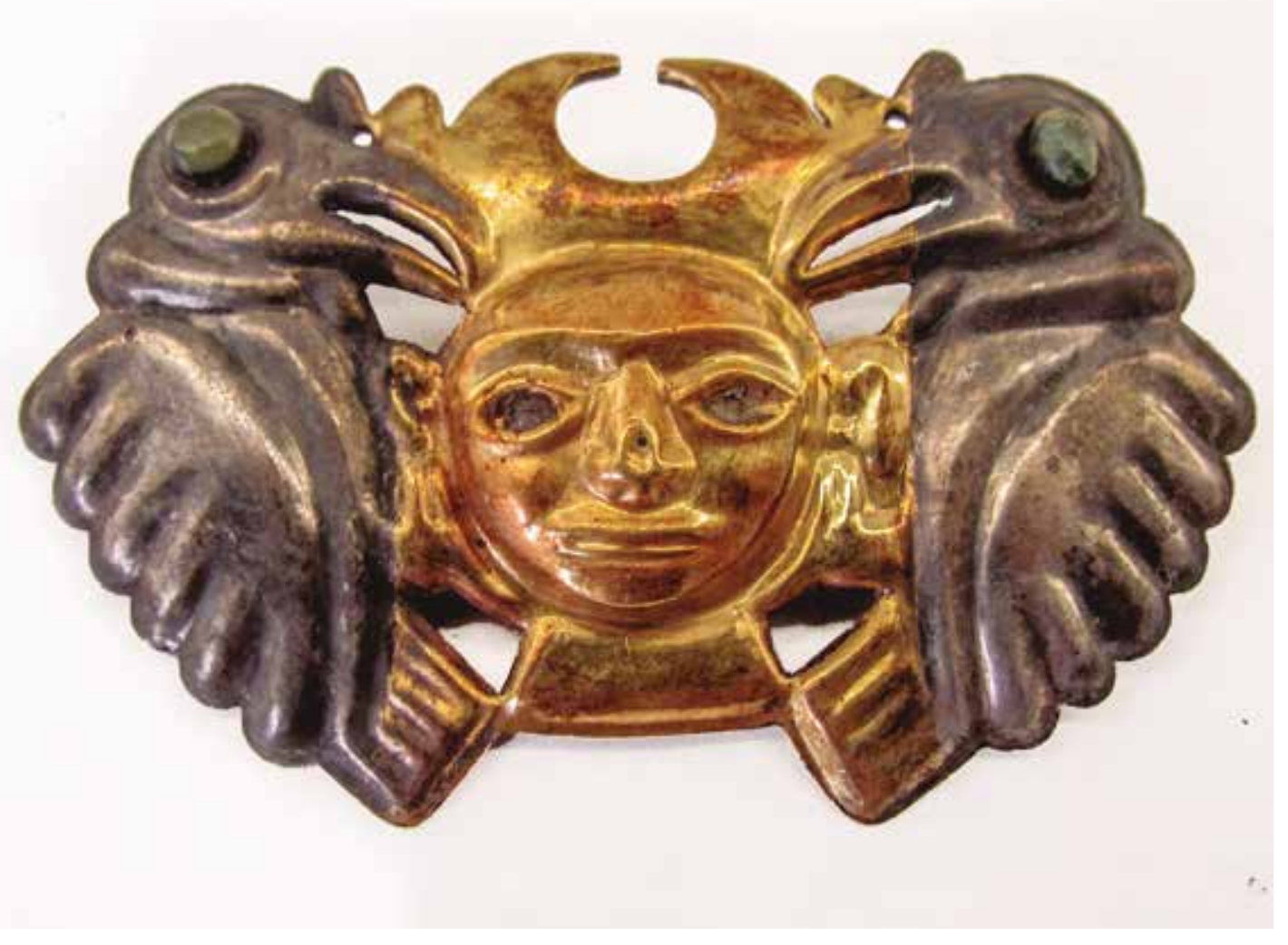

Fig. 43. Nariguera de la Señora de Cao. Colección Museo Cao (foto de Luis De La Vega).

\section{El HUEVO CóSMICO Y SU SIMBOLISMO EN LA CREACIÓN HUMANA}

Una figura ovoide aparece en la misma línea inferior del mural mayor de Huaca de la Luna, en la forma de un huevo de carácter liminar, que contiene a un ser antropomorfo de frente con un tocado semilunar, que lleva en la mano derecha un cactus de San Pedro y en la mano izquierda una porra. En el caso de la imagen del mural menor de Cao, la figura está dañada, quizás tiene la misma representación, pero con el agregado de una figura estelar sobre la cabeza del personaje (figs. 44-45). Alfredo Narváez (2014: 191) llama la atención cuando indica que las figuras en forma de burbujas, óvalos o huevos en la iconografía constituyen metáforas de preñez, matriz, contenedor y generador de vida.

Me parece extraordinario que este ser llevara en la mano la planta de San Pedro o Wachuma, conocida en el mundo andino como una planta para uso mágico-religioso y que ha sido utilizado en todos los tiempos para los rituales o ceremonias (Franco 2015). Esta notable representación se vincula con los orígenes, con la naturaleza humana, estelar y cósmica, y la aparición del ser sobrenatural con la planta representa, precisamente, la continuidad de una antigua tradición iconográfica reconocida siglos antes de los moche en una lápida que ornamenta la pared interior de la plaza circular del tem- 
plo antiguo de Chavín de Huantar y descubierta por Luis Lumbreras en 1972 (ver Burger 1992, 2011 y Rick 2006) (fig. 46). Se trata, sin duda, de la representación de un ser sobrenatural de perfil, trabajado en bajo relieve, que ha sido caracterizado por Burger (1992:125) como un sacerdote antropomorfo que tiene en sus manos un cactus de San Pedro. Hay tres elementos esenciales incorporados en su configuración: el felino, el ave rapaz y la serpiente, que determinan posiblemente el fundamento divino y cósmico de esta criatura sobrenatural asociado con el cactus sagrado. En definitiva, este ser de la cabellera y el cinturón de serpientes del estilo Chavín es el antecedente de la divinidad moche conocido como el personaje antropomorfo de cinturón de serpientes (PACS).

En el caso del mural mayor de Huaca de la Luna, la figura ovalada no se encuentra rodeada por figuras estelares, únicamente aparecen dos felinos casi enfrentados en la parte inferior, como si se dirigieran a otra figura estelar magnificada que aparece sobre la luna nueva. En el caso del mural menor de Cao, la figura ovalada está rodeada de más de cuatro estrellas, tomando en cuenta a un pequeño felino que ocupa quizás el lugar de una figura estelar. Según nuestra proposición anterior (ver Franco y Vilela 2005), estas figuras estelares podrían estar representando las pléyades o "siete cabrillas" que se muestran agrupadas en el firmamento. Vamos a hablar sobre esta pléyade tan importante en la vida de los aborígenes del norte peruano.

El cronista Bernabé Cobo (1956 \{1653:159\}) decía que para los nativos de la costa norte las "siete cabrillas" eran consideradas como progenitoras, encargadas de la preservación humana y del movimiento del tiempo, a partir del cual se tomaba cuenta del transcurso del año. Calancha (1976-78 [1638]:554) otro de los cronistas que recoge mucha información sobre la gente de la costa norte, afirma que a partir de la salida de las "siete cabrillas" contaban el año, señalando que“... aquellas estrellas les daban de comer, y criaban sus sembrados, y tenían el sustento, ley de gratitud, y aún represión contra nuestras ingratitudes".

Se ha indicado que este conjunto de estrellas aparecen en el firmamento en el mes de junio, considerado como primer día del año, asociado fundamentalmente al período agrícola, observándose hasta noviembre, después del cual, del 19 de abril hasta el 2 de junio desaparecen (Urton 1982: 258; Sakai 1998: 45-47; Berezkin 1987: 272). Estos indicadores astronómicos, nos conducen a plantear que tanto en el siglo XVII como en épocas pretéritas, la aparición de las pléyades o "fur" (lengua yunga) en el cielo revelaba el inicio del ciclo agrícola (Hocquenghem 1987: 25).

Otras referencias indican que la observación de las collca o pléyades ayudaban para hacer predicciones climáticas y agrícolas, tanto que, si las estrellas aparecían grandes y luminosas, se trataba de una señal positiva para la siembra y futura cosecha, y si las estrellas se representaban pequeñas y poco luminosas, indicaban un presagio negativo (Arriaga 1920 [1621]: 223). En suma, podemos entender que las pléyades servían de modelos para el desenvolvimiento de las actividades de los seres vivientes.

La versión de los cronistas, naturalmente con ciertas reservas, debemos tomarla en cuenta para enriquecer lo que tal vez los moche quisieron expresar. A menudo se hace mención al huevo en los mitos de origen de la costa norte y que tendrían relación con el concepto de "huevo cósmico". Calancha (1976-78 [1638]) sostiene que de tres huevos, de oro, plata y cobre, se engendraron los nobles, las mujeres de los nobles, plebeyos y el resto de la descendencia. Otras versiones compatibles recogidas de otras regiones del mundo andino, a decir del padre Avila (1966 [1598?] Cap. 16), extirpador de idolatrías, en el documento de "Dioses y Hombres de Huarochiri", se dice que el dios Pariacaca y sus hermanos salieron de cinco huevos puestos en el cerro Condorcoto, que en un principio habían salido en forma de halcones y luego tomaron la forma humana. Un concepto también parecido es señalado por los padres agustinos de Huamachuco (Padres Agustinos 1992 [1561?]: LIII), en el que dan cuenta 
que la diosa Cautaguan pare dos huevos de donde sale después el dios del trueno Apo Catequil y su hermano Piguerao.

El arqueólogo Masato Sakai (1998: 45-60) hace un interesante análisis sobre el sentido que tuvieron algunas estrellas en el pensamiento nativo norteño. Se refiere a la posible identificación de las cuatro estrellas que menciona el cronista Calancha (1985[1638]: 554), cuando se refiere a que, de dos estrellas, las más luminosas, nacieron los reyes, caciques y nobles en general, y de las otras dos estrellas, menos luminosas, nacieron los plebeyos, pobres y mitayos. Según su análisis, basándose fundamentalmente en el mito de las estrellas y los hombres, recopilado en Lambayeque por León Barandiarán (1938:7-9), lega a la conclusión que las cuatro estrellas estarían identificadas con las constelaciones del Can Mayor y el Pez Austral, siendo el Can Mayor la estrella de las clases superiores, en tanto, el Pez Austral es la estrella de las clases inferiores.

Puede haber, probablemente, otras versiones similares con relación al origen de las divinidades, pero está claro que el pensamiento moche expresado en los murales tiene relación con las fuentes etnohistóricas indicadas, más expresamente con los mitos de origen vinculados con el numen, las deidades o seres míticos con las constelaciones o pléyades, un concepto religioso universal que no solo se encuentra en el mundo andino, sino también en la mitología de las antiguas culturas clásicas.

\section{El Escorpión y su Relación con las Pléyades}

En el lado derecho de la figura ovalada, visto en los murales mayor de Huaca de la Luna y menor de la Huaca Cao Viejo, se observa la figura magnificada de un alacrán o escorpión con dirección a los planos superiores, virtualmente asociado a un lucero en la parte superior y una serpiente en la parte inferior (muro mayor de la Huaca de la Luna) (fig. 47).

Según Guillin (1947:34) y Urton (1982: 235-236), la “cola de escorpión”, conocida en la sierra como el "arado", tiene una estrecha relación con la aparición de las pléyades conjuntamente con la "cruz de mayo" (Cruz del Sur) y el "lucero" de la mañana (Venus). Sakai (1998:53,58-59) indica que el agrupamiento de todas estas estrellas, incluida la "cola de escorpión", salen en el transcurso de un día, encabezado por las pléyades que señalan el inicio del tiempo y del año. Estas referencias ayudan a interpretar la trascendencia y aparición de esta constelación "la cola de escorpión" en el terreno celestial, nocturno, asociado a la actividad agrícola o es visto como generador de plantas (ver también Golte (1994:71).

Rodolfo Sánchez (2012: 37) por su parte, da referencias interesantes sobre el ciclo reproductivo del "Escorpión Dorado Peruano", dice que son animales de la noche, con mucha resistencia a las temperaturas, que pueden vivir hasta nueve meses sin agua ni comida; indica, además, que el período de gestación se produce dos veces al año: uno de agosto a octubre (primavera) y otro de enero a marzo (verano), lo que daría lugar, según su opinión, que en el hemisferio sur el ciclo reproductivo del alacrán correspondería con el mundo de adentro/abajo, que va del equinoccio de primavera al equinoccio de otoño. Debemos indicar que, a excepción del mural menor de la Luna, en los murales mayores de Cao Viejo y la Luna, el escorpión se encuentra hacia el lado izquierdo de la figura ovoide, mientras que en el mural menor de la Luna el escorpión se ubica en el lado izquierdo.

En una representación compleja de la iconografía moche, se puede observar a un alacrán magnificado acompañando a un ser sobrenatural de carácter mítico-estelar, que es conducido en un anda por cuatro personajes con propulsores y acompañado por dos seres, uno mayor y otro menor, que lo escoltan. Del ser sobrenatural brotan plantas y lleva, además, un báculo convertido en una planta. Hay otros seres adelante que cogen una figura esférica de doble línea que hace recordar a la esfera 

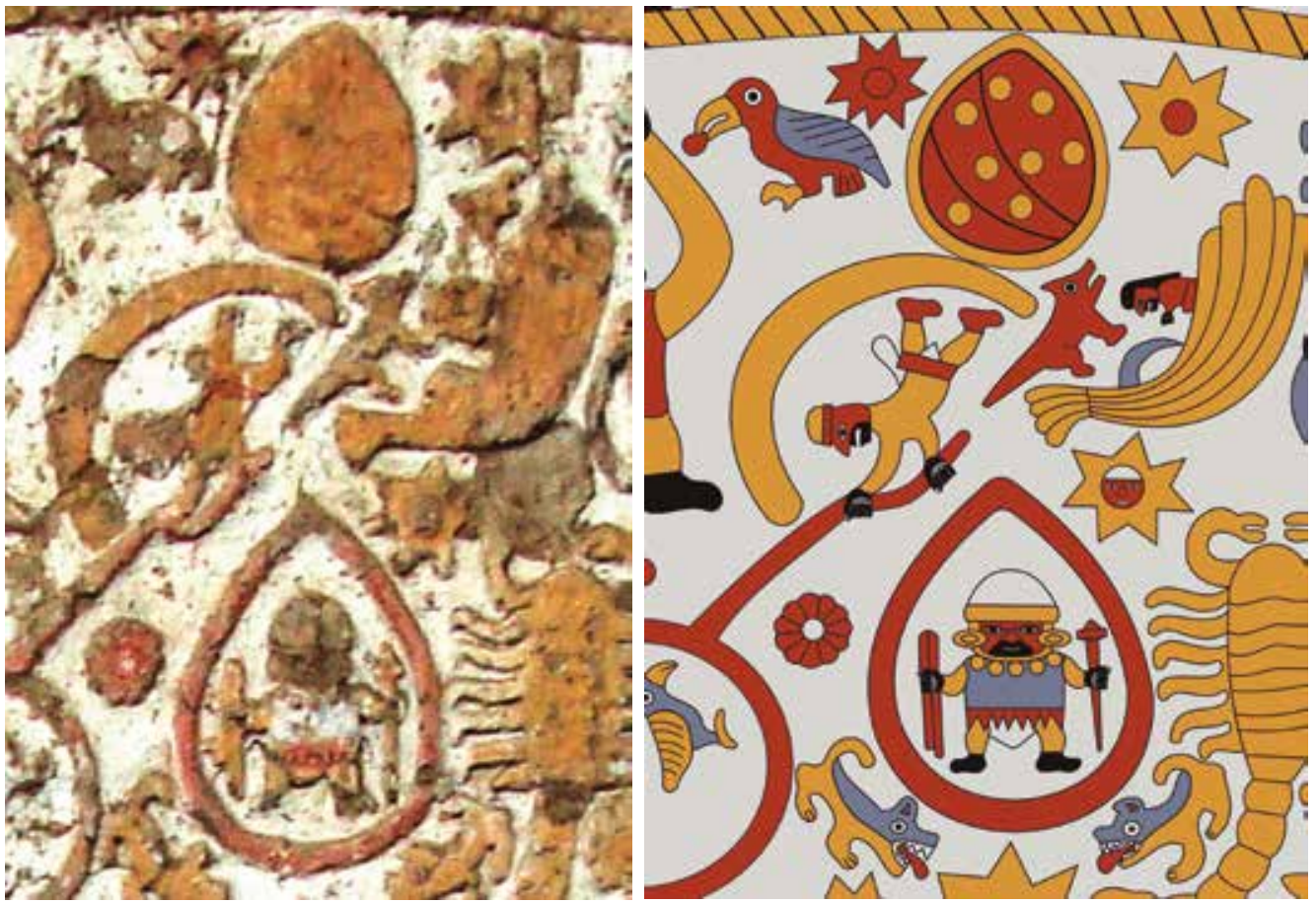

Izquierda: Fig. 44. El huevo cósmico en el muro mayor de la Huaca de la Luna (ilustración de Luis De La Vega). Derecha: Fig. 45. Reconstrucción del huevo cósmico con un ser mítico que coge un cactus de San Pedro y una porra, basado en el muro mayor de la Huaca de la Luna (ilustración de Luis De La Vega).
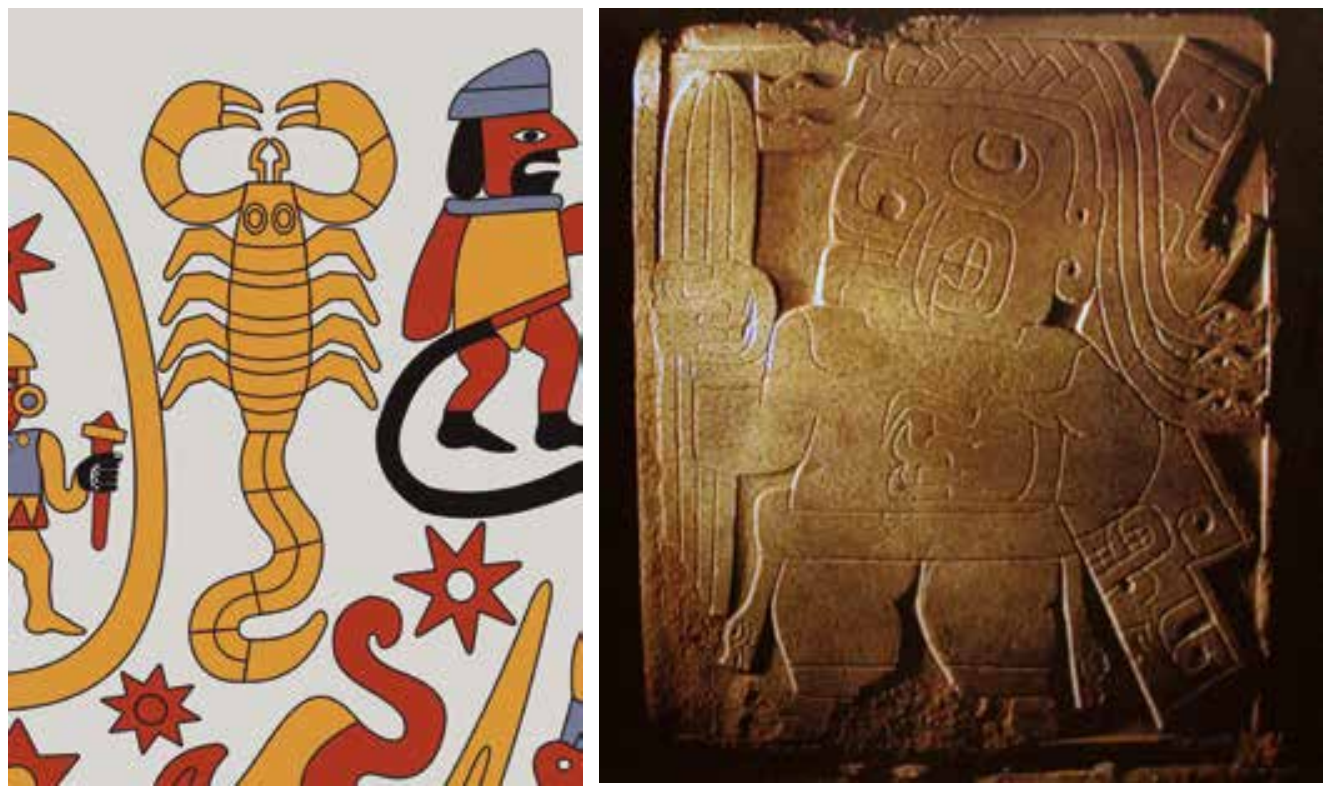

Izquierda: Fig. 46. Lápida de piedra hallada en Chavín de Huantar, corresponde a un ser sobrenatural con cabellera de serpientes que coge un cactus de San Pedro. Derecha: Fig. 47. Reconstrucción del alacrán asociado al huevo cósmico, basado en el muro menor de la Huaca Cao Viejo (ilustración de Luis De La Vega). 
que coge el personaje en el plano superior. Esta escena se encuentra también acompañada de figuras estelares, al parecer con una íntima relación con el lado derecho de la figura ovalada, es decir, asociado al alacrán como generador de las plantas (fig. 48).

\section{LA LUNA CON LOS ANIMALES LUNARES O ESTELARES}

Debajo de la figura ovoide, aparece la figura de la luna nueva a cuarto creciente, con dos felinos enfrentados y separados por una figura estelar mejor vista en el mural de Cao Viejo y un poco dañada en el mural mayor y menor de la Huaca de la Luna, estando la figura estelar sobre los felinos. Se asocian a este contexto dos figuras estelares colocadas en los laterales de la Luna y la figura de un búho devorando una lagartija en el lado exterior derecho, en tanto que, en el mural mayor de la Luna, en el lado izquierdo, ya no corresponde a un búho, sino más bien al parecer a un gallinazo o cóndor siempre con el mismo simbolismo de aves estelares.

Hablemos primero de la importancia de la Luna en la fase que aparece figurada en el mural. Rodolfo Sánchez (2012: 54-58) hace una buena exposición sobre la importancia de este satélite y su intervención directa en las actividades agrícolas y marinas. Indica que los moches habrían manejado ideas precisas respecto a los cambios lunares y su influjo en los procesos metabólicos de plantas y animales y, por consiguiente, en la configuración de ciertos ritmos biológicos significativos. Llama la atención de la posición de la luna nueva a cuarto creciente y su relación con la rápida germinación de las semillas a causa de la abundancia de agua, favoreciendo el crecimiento homogéneo de las plantas.

Con respecto a la influencia que causa la Luna en la vida marina, algunos investigadores consideran que la luna nueva a creciente tiene relación con la balsa o caballito de totora y era venerada por los pescadores por su influencia en las mareas (ver Guillin 1947:34; Rostworowski 1981:134; Hocquenghem 1987: 127).

Los felinos asociados a la Luna son considerados como "animales lunares" (ver Kutscher 1954; Alcina Franch 1987:192; Benson 1972:44; Bruhns 1976). El felino asociado a la Luna es conocido con varios nombres: "monstruo de la luna", "animal crestado", "animal lunar" "animal fantástico”, etc. Está en discusión cuál sería el animal que le daría origen. Según Mackey y Vogell (2003: 329) sería el "gato montés" (Oncifelis colocolo) y según Bruhns (1976) este felino tendría su origen en la cultura Recuay. Según Alfredo Narváez (2014: 172), se trataría de la figura del perro peruano sin pelo debido a razones iconográficas y etnográficas. Debe decirse, además, que en esta figura resaltan los apéndices escalonados y las volutas que brotan de la cabeza y la cola y que permiten resaltar su carácter mitológico o sobrenatural (Ver Kutscher 1954: Lams. 44-49) (fig. 49). (Franco y Vilela 2005, fig. 155 A). Incluso, podemos observar a estos felinos enfrentados en la parte superior de un ídolo encontrado enterrado en uno de los recintos de la Huaca Cao Viejo (Franco et. al. 1997: 123-134) (fig. 50). Detalle de los felinos del ídolo) y en uno de muros del recinto-mausoleo de la Señora de Cao (fig. 51). foto del mural recinto mausoleo), donde el animal lunar se encuentra dentro de un contexto arquitectónico Moche Temprano, lo que permite entender que este animal fue caracterizado como una divinidad asociada a la Luna y consecuentemente vinculado al agua que viene de las montañas. En otras representaciones iconográficas, este animal tiene atributos de "ciervo-serpiente-jaguar" que según Hocquenghem (1987: 213, figs. 210-211) representan los símbolos de cambio, de la alternancia y de la reinstauración del orden (fig. 52).

En el Museo Nacional de Arqueología y Antropología e Historia del Perú, hemos registrado dos piezas de cerámica de estilo Mochica III y IV, con representaciones similares a los animales lunares de 
los Temas Complejos. Una de las piezas Moche III es una botella asa estribo con la representación en dos planos similares de un felino sobre la luna en creciente y tres motivos de estrellas asociadas a esta escena. Otra botella Mochica IV con asa estribo y representado en plano relieve muestra en una de sus caras la figura de un felino sobre la luna en creciente, y en la otra cara dos estrellas con apéndices circulares y rostro humano, de características similares a una de las figuras estelares definidos en los Temas Complejos de la Huaca Cao Viejo. En ambos casos, revelan una concordancia con el motivo de los animales lunares (figs. 53-54).

Hay mitos que consideran que los felinos están relacionados con la constelación llamada "Chinchay", que según las creencias de la época, era un felino que devoraba periódicamente al Sol y la Luna (Sharon 1980: 126). Santa Cruz Pachacuti (1993 [1613?]: F214-224) se refiere al Chuquechinchay como una deidad venerada que le hacían sacrificios.

Las tres estrellas que aparecen asociadas a la luna (dos laterales y una central), podrían tener correspondencia con la constelación llamada "pata", adorada por los pobladores de Pacasmayo. Calancha 1976-78 [1638]: 1243) indica que los nativos veneraban a dos estrellas llamadas "pata", equivalente a las Marías, que la estrella de en medio era un ladrón malhechor, facineroso, que la luna quiso castigar, enviando a dos estrellas que lo llevasen asido para ser devorados por los buitres, que eran gallinazos, figurados en cuatro estrellas y que estaban por debajo de las Marías. Es posible que esta creencia registrada por Calancha tenga quizás su equivalente a que la estrella sea devorada por felinos, como se puede observar en la iconografía de una vasija de estilo Post Moche (Figs. 55-56).

La presencia de un búho (Buho virginianus ñacurutú "búho grande"), ave nocturna, devorando una lagartija en asociación a la luna, se vincula simbólicamente a las creencias y el culto moche reflejadas tantas veces en la iconografía. El búho tiene la facultad de eliminar roedores, lagartijas, serpientes y es considerado como protector agrícola (Bourget 1996: 39). Hocquenghem (1987: 84, 125)señala que el búho sería el "dueño de la vida y la muerte", un ancestro mítico en la iconografía Moche y según cita a Polo de Ondegardo, esta ave tendría asociación con el "trueno-rayo-granizo" de los Incas, y se le podía observar de noche en la Vía Láctea, cogiendo una porra y emitiendo rayos al moverse. En efecto, la escena búho-lagartija asociada a la luna, podría indicar, sin duda, un simbolismo vinculado con la actividad agrícola, la lluvia y la reproducción de los seres vivos. Su figuración en la iconografía es sumamente importante, tanto que Makowski (1996) le califica como una de las principales divinidades del panteón Moche (Fig. 57).

\section{Las Divinidades o Ancestros Míticos Fertilizadores}

Hay un motivo magnificado de color amarillo que aparece en el mural mayor de la Luna, en el lado derecho de la Luna, en cambio en el mural menor de Cao aparece en el mismo lado, pero un poco más abajo. Este motivo por su ubicación y mayor escala tiene al parecer una significación muy especial. En una anterior propuesta (Franco y Vilela 2005: 112) habíamos señalado que se tratarían de arañas en eclosión, sin embargo, ahora es necesaria una revaluación, considerando ahora su presencia en mayor tamaño en los murales de la Huaca de la Luna.

A pesar que tengo todavía algunas dudas, mi percepción es que se trataría de la representación de escorpiones en nacimiento, asociado a una figura estelar, equivalente al escorpión que aparece al costado de la figura ovoide. En el mural menor de Cao se asocia a un personaje que lleva en sus manos quizás un palo de labranza para sembrar, mientras que en el lado derecho aparece un felino asociado a otra figura estelar. En el mural mayor de la luna, estos motivos aparecen asociados a dos figuras estelares de mayor magnitud que sus similares y la presencia de una serpiente que está en movimiento 


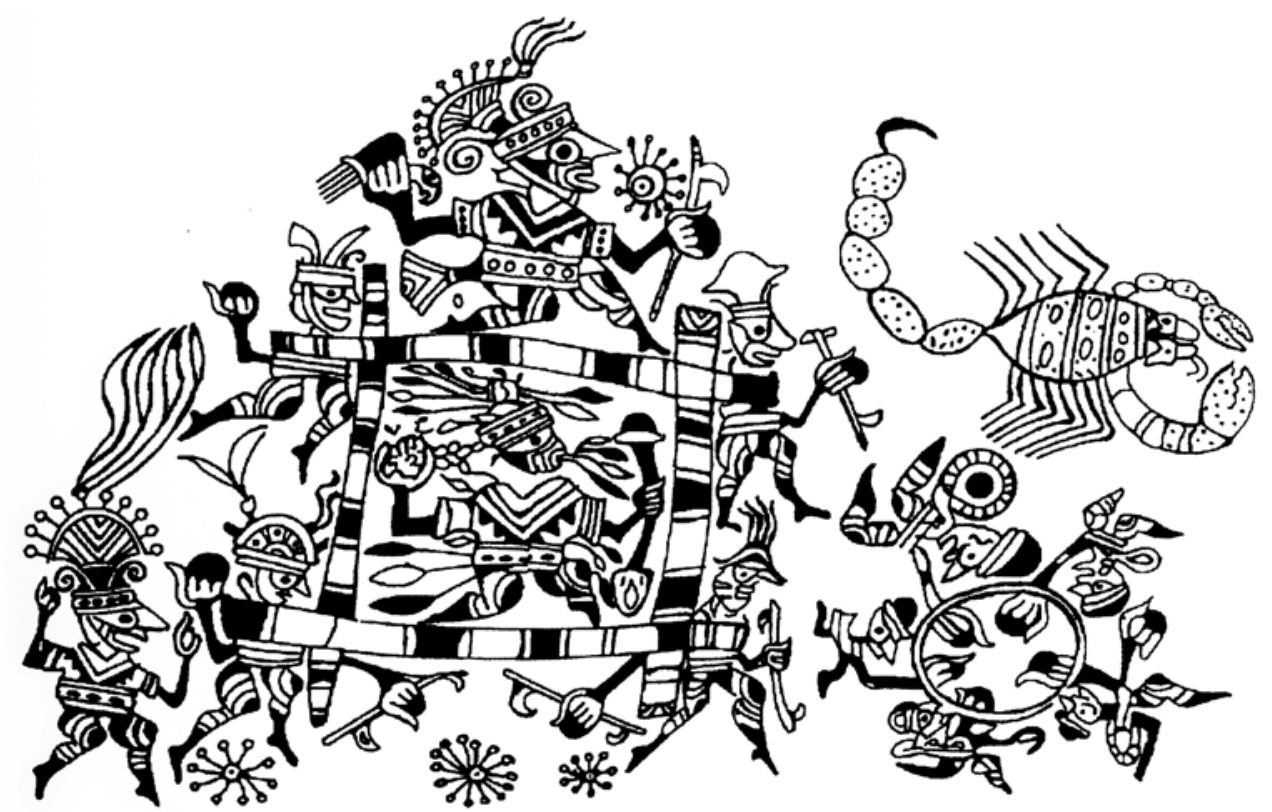

Fig. 48. Representación de un ser asociado a los alimentos y al alacrán compleja en la iconografía Moche (Tomado de Donnan y McClelland 1999).

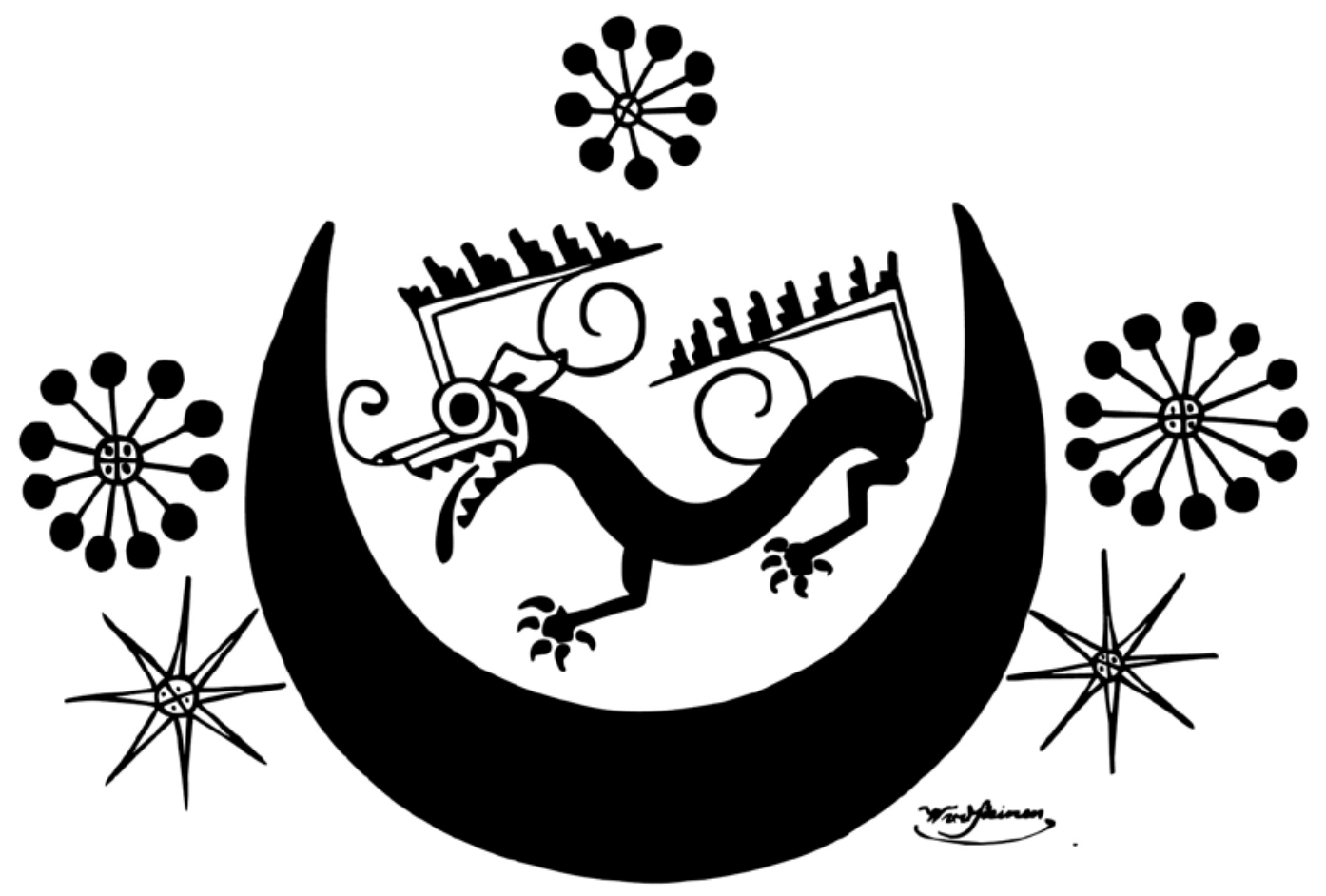

Fig. 49. Escena del animal lunar asociado a la Luna y a figuras estelares (Tomado de Hocquenghem 1987). 


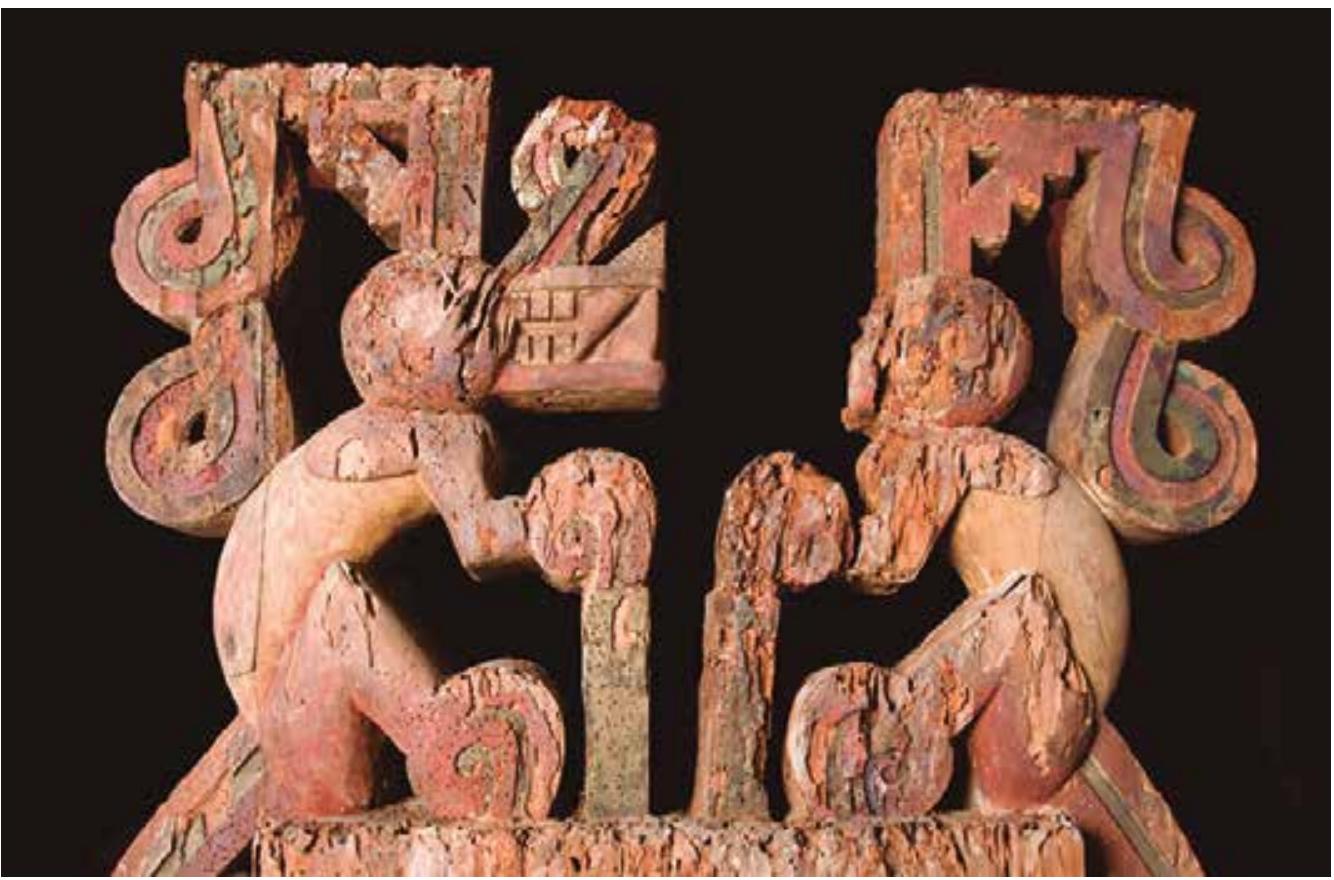

Fig. 50. Sección superior del ídolo de madera hallado en la Huaca Cao Viejo. Destacan los animales lunares en pareja.

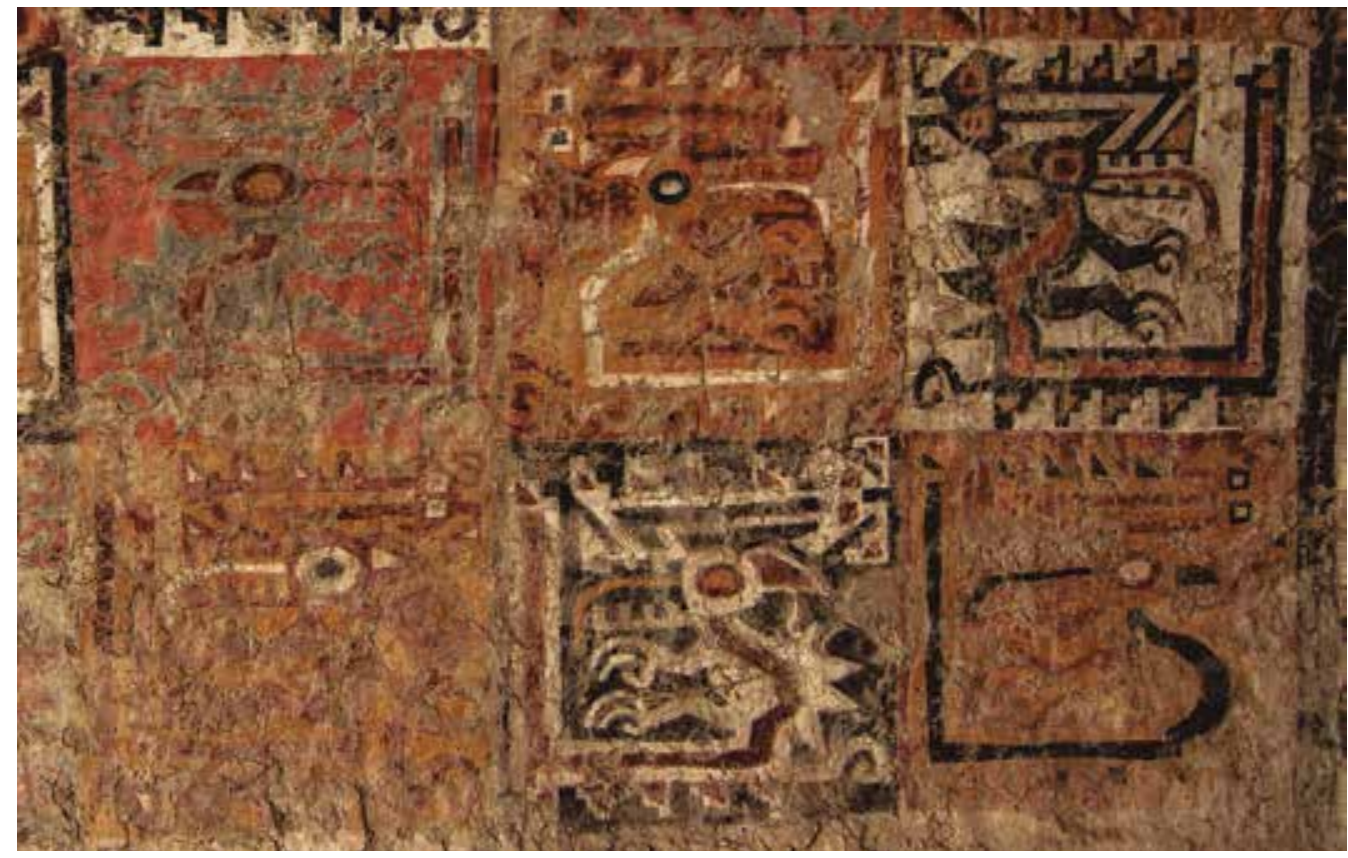

Fig. 51. Pintura mural en la cara oeste del recinto esquinero en el ambiente de la Señora de Cao. 


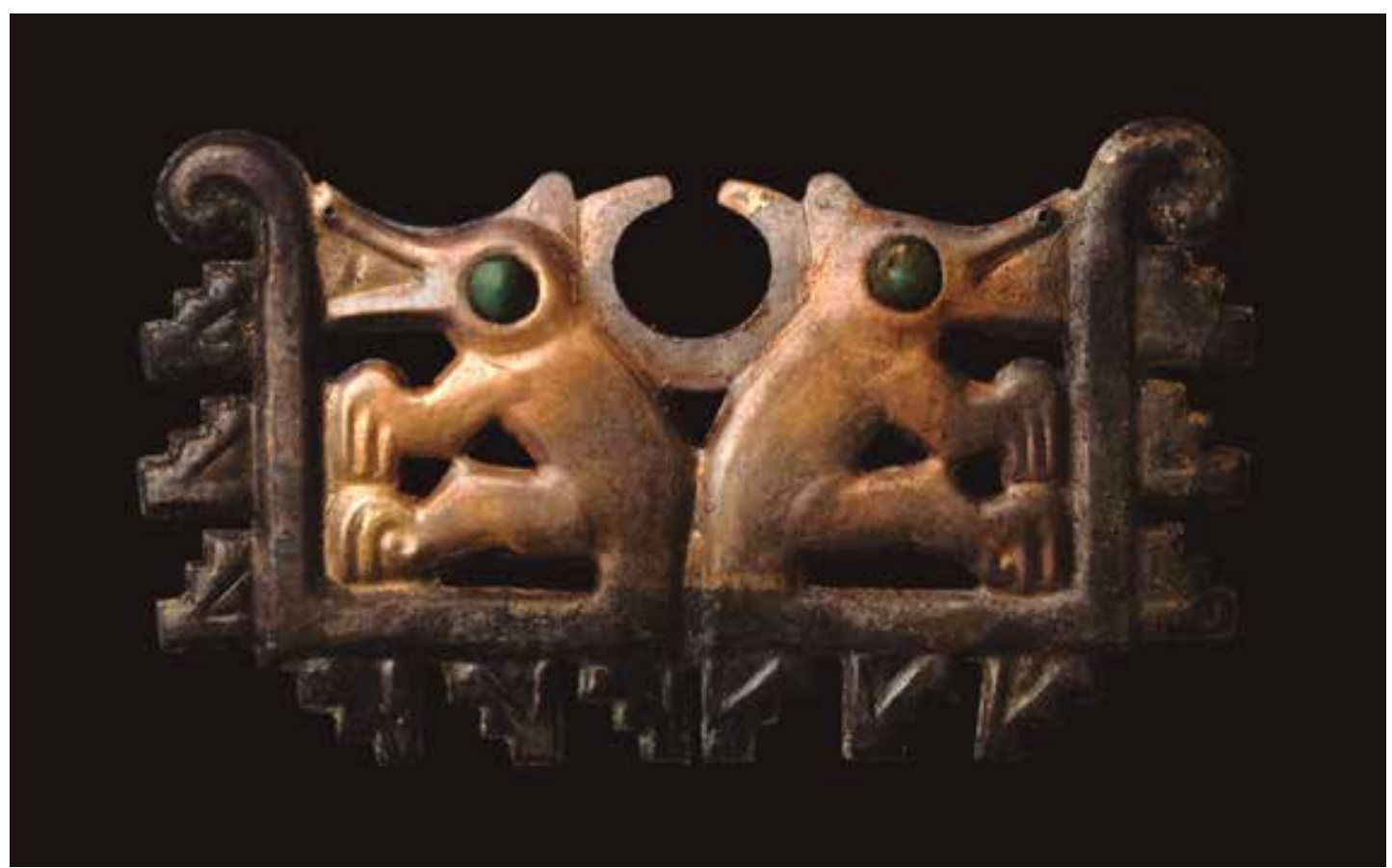

Fig. 52. Animales lunares en una de las narigueras de la Señora de Cao. Colección Museo Cao.
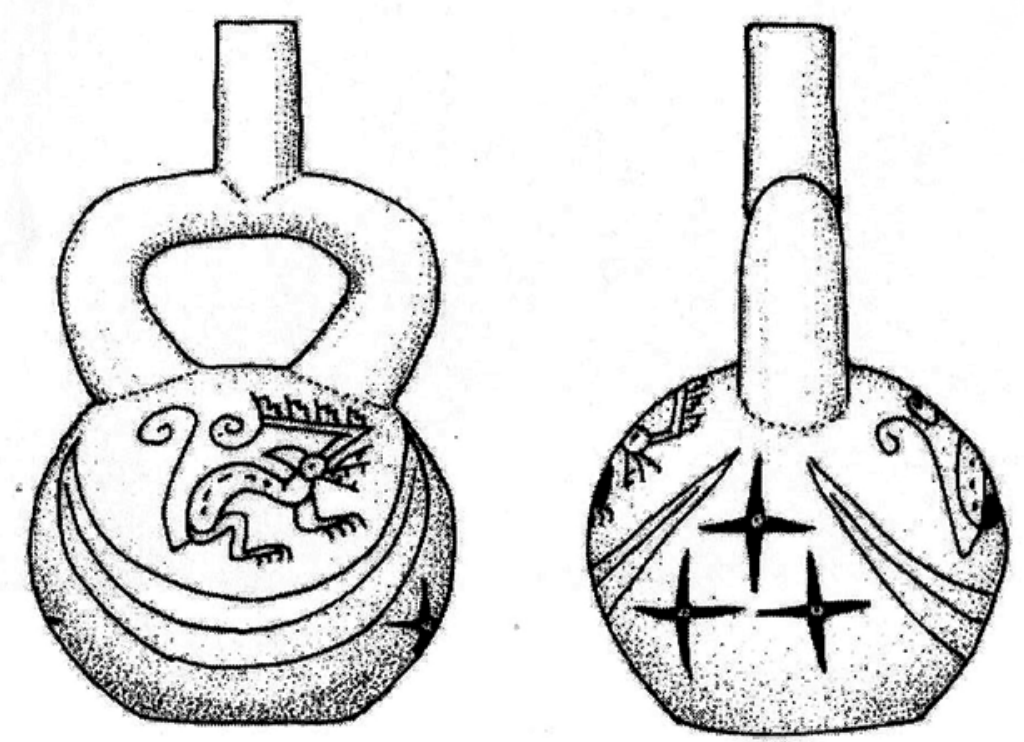

Fig. 53. El animal lunar en una vasija Moche (Colección MNAAHP/04302). 

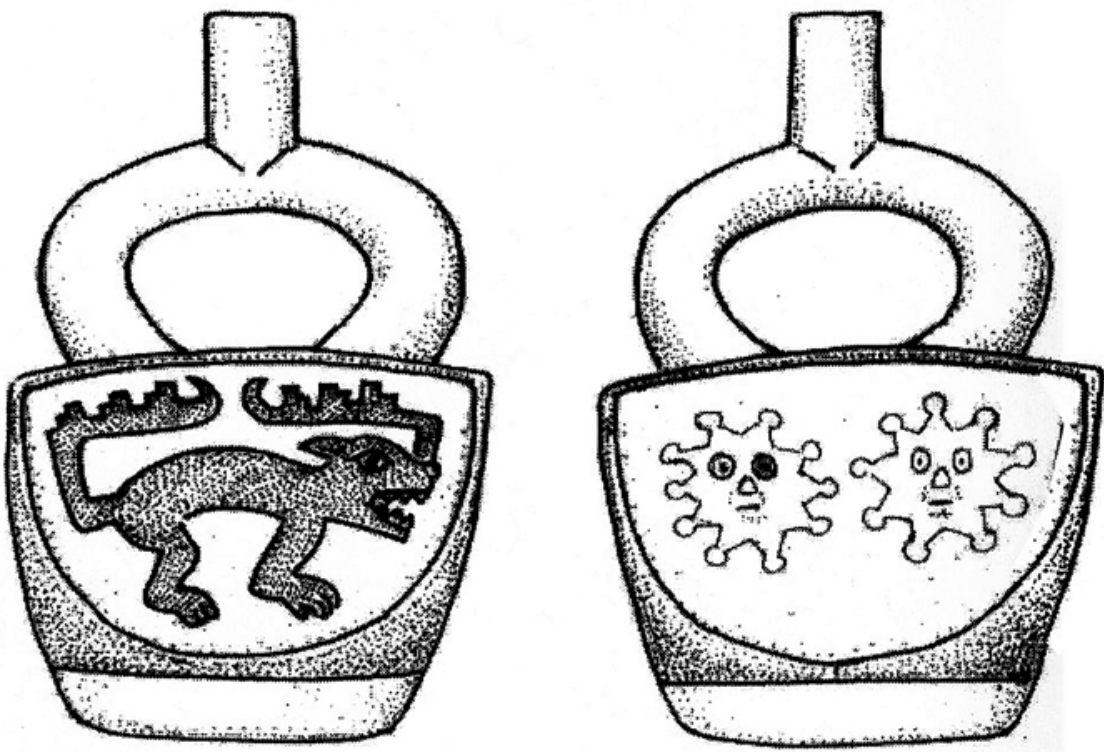

Fig. 54. El animal lunar y figuras estelares en una vasija Moche (Colección MNAAHP/03489).

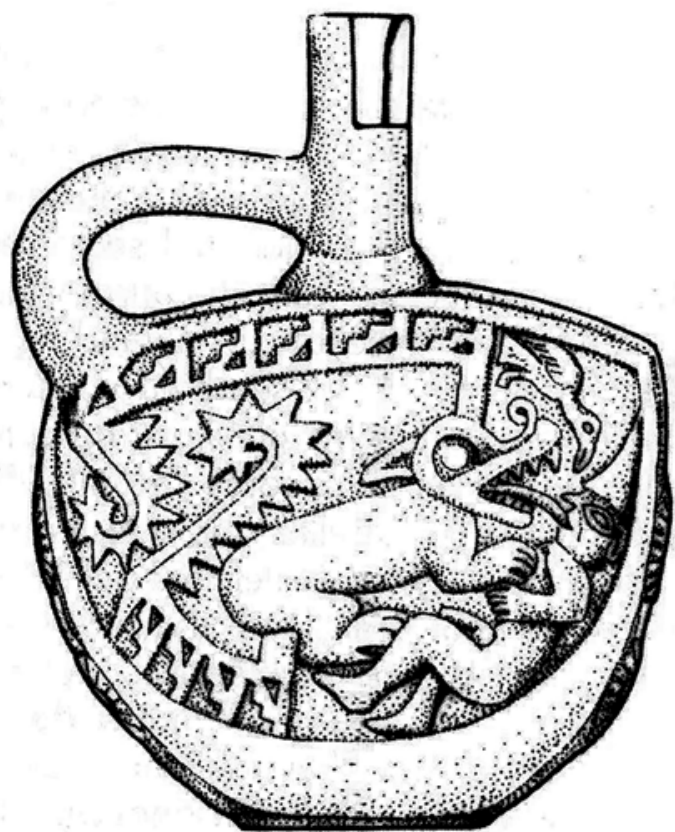

Fig. 55. Felino lunar atacando a un ser humano (Colección particular). 


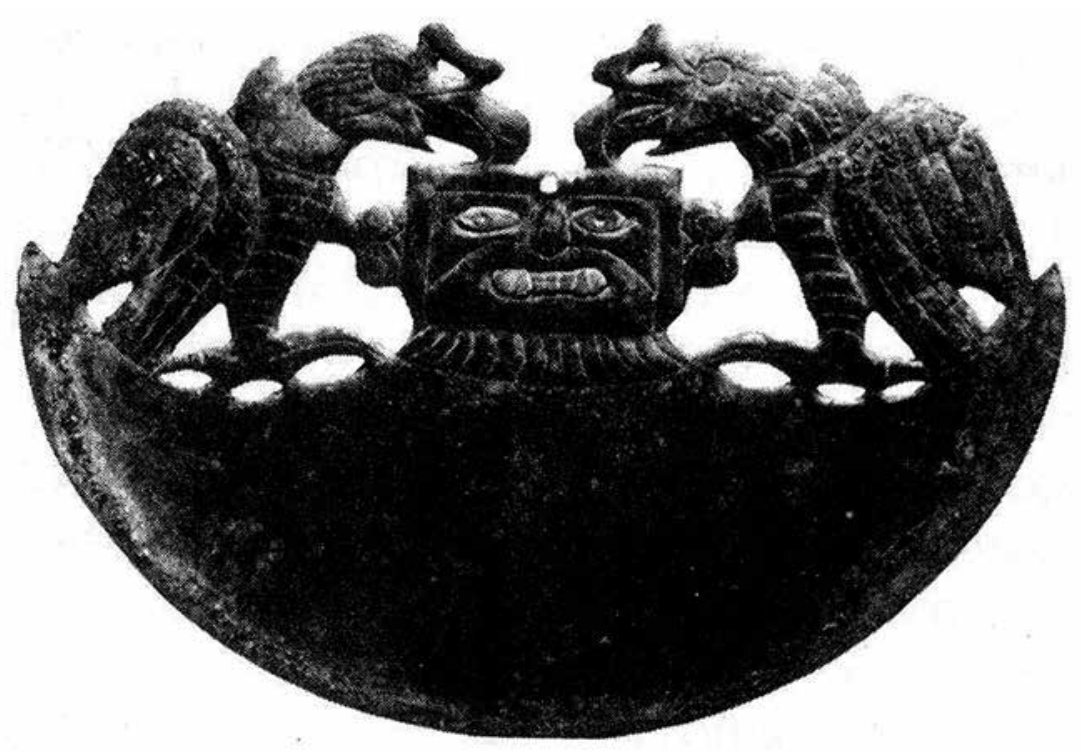

Fig. 56. Nariguera metálica hallada en Loma Negra (Tomado de Lapiner 1976).

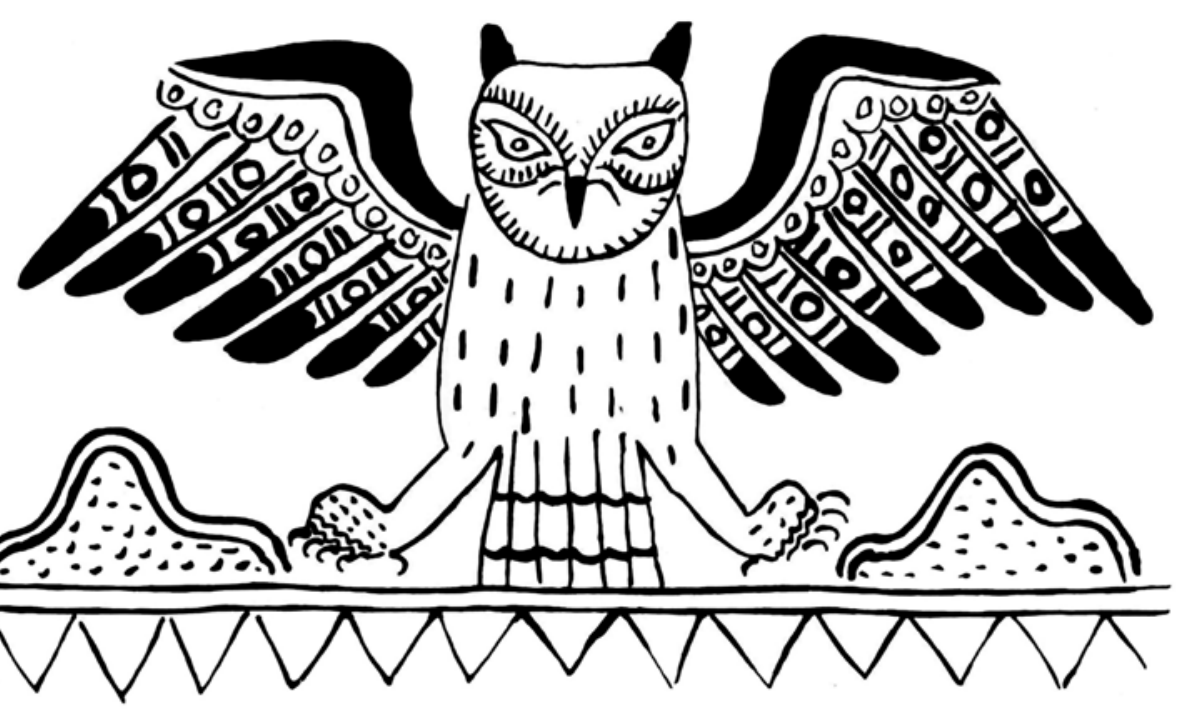

Fig. 57. Buho con las alas abiertas en la iconografía Moche (Tomado de Donnan y McClelland 1999). 
y que en el mural de Cao se encuentra en la parte inferior. En verdad, todavía sigue siendo una incógnita su definición exacta, debido a que en el mural de Cao su representación es mejor culminada, a partir del cual nos permite aproximarnos a su identificación. (figs. 58-59).

En realidad, hay muchos motivos asociativos hacia el lado derecho, observados en el mural de la Luna y parcialmente en el mural mayor de Cao, como por ejemplo, ubicamos a un personaje de frente que tiene los brazos levantados y que muestra sus genitales, y junto a él, aparece una mujer de perfil con cabello largo, túnica larga y cinturón. En el caso del muro mayor de la Luna, este personaje aparece al parecer amarrado a un tronco y acompañado de gallinazos (Coragyps atratus) y una figura estelar, mientras que la mujer, en este caso, se encuentra un poco alejada del personaje. Por las características de esta escena, parece que se trata del personaje supliciado amarrado a un tronco de árbol que aparece con frecuencia en la iconografía Moche (figs. 60-61).

Luego se registra en los niveles inferiores, muchas imágenes de divinidades fertilizadoras asociadas a la fauna y flora de un ecosistema costeño, que se integran de algún modo a todo el contexto de creación asociado seguramente a ciertos mitos, especialmente vinculados con el mundo agrícola terrestre y la influencia directa de los cambios de la Luna. En este contexto se le ha dado énfasis a ciertas divinidades que a continuación vamos a describirlas.

\section{Divinidades Fertilizadoras}

Se destaca la figura de una divinidad femenina portando dos báculos que es asistida por los costados por dos personajes asidos de los báculos, visto con mayor precisión en los dos murales de Cao, pero también se encuentra en sus similares de Huaca de la Luna. En el caso del mural mayor de Cao Viejo, aparece un murciélago de frente con las alas abiertas y con la cabeza orientada hacia la divinidad. Este animal nocturno tiene estrecha relación con la agricultura, porque desempeña un papel ecológico vital como polinizador en la dispersión de semillas, tan importante que muchas plantas tropicales dependen por completo de este mamífero. Aparece también en la iconografía tomando formas humanas en rituales de libación y asociado a vasijas ceremoniales (ver Donnan y Mc Clelland 1999: 18, figs.1.13-1.14) (fig. 62).

La divinidad de los báculos tiene una fuerte tradición iconográfica en el Perú Prehispánico. Esta escena se repite en los dos Temas Complejos, pero casi ausente en la iconografía Moche en general. Las representaciones que estarían relacionadas son aquellas en las cuales se representan a personajes de frente y sosteniendo tallos de plantas (maíz o yuca) a modo de báculos (Hocquenghem 1987: Fig. 166). Aparece claramente en la Estela de Raimondi de la época Chavín, continúa en la imaginería de Tiwanaku (Puerta del Sol), Wari y Pachacámac (ver De Bock y Zuidema 1991: 461; Cook 1994: 177, 184), aparece en la sierra Sur dentro del estilo Nasca 9 y Chakipampa(Cook 1994: 176-177). El mismo concepto de la imagen en cuestión, asociada a una fase tardía de Moche, aparece en un mural de carácter geométrico en la Huaca de la Luna (ver Bonavia 1985: Fig. 43).Se le ubica también en la iconografía de los períodos post mochica, donde a menudo es mostrado en su condición de divinidad masculina o femenina portando báculos convertidos en plantas alimenticias, por eso su carácter de divinidades fertilizadoras (ver Carrión Cachot 1959: 57-66).

La representación de personajes femeninos es inconfundible, porque aparecen en tres acciones que únicamente se pueden observar en el mural mayor de Cao, en uno de los casos, como ya se ha descrito, asiste al personaje amarrado al árbol; en otro caso, coge al parecer un disco y tiene el vestido con listados verticales, y también aparece de perfil frente a una serpiente con una de las manos levantadas más arriba que la otra que sugiere un gesto ritual. 
Otra divinidad fertilizadora observada con más claridad en los murales de Cao Viejo se encuentra sobre un árbol con frutos (fig. 63). Una libélula magnificada aparece en una de las ramas laterales y en la parte superior se observa un ave terrestre en vuelo, no identificada con claridad, pero podría tratarse de un picaflor (picaflor Amazilia). La divinidad se encuentra de frente con los brazos y piernas abiertas, con camisa reticulada, que aparece en medio de un árbol frondoso, que por sus características podría calificarse como el "árbol de la vida". A sugerencia del profesor Alfredo Marti de la Facultad de Ciencias Biológicas de la Universidad Nacional de Trujillo, el árbol es de hojas gruesas, el fruto de forma redondeada o alargada, a veces con punta aguda, correspondería al árbol de Zapote (Cappariss cabrida). Pero, también es cierto, que existen en la iconografía moche otras especies de árboles con frutos y/o semillas incorporados a la esfera de lo sagrado, como por ejemplo el llamado ulluchu, el lúcumo, el molle o el algarrobo, por citar los más importantes.

El árbol es el que establece el contacto entre el mundo de los hombres y el de las divinidades, "es el árbol de las generaciones....significa el acto de fertilización inicial del año agrícola y, en su representación ritualizada, un acto de creación cíclica, necesario para la reproducción del mundo"(Hocquenghem 1987: 77).

La libélula (anisóptero) es un insecto que vive en zonas pantanosas, charcos y ríos, poco común en la iconografía, son consideradas como valiosas depredadoras que controlan las poblaciones de mosquitos y moscas. Al parecer, no existe una especie definida asociada al "árbol de la vida", hay otras especies con atributos especiales en el discurso mítico, como los monos, loros o guacamayos, halcones, etc. precisamente en el muro mayor de Cao Viejo, en el lado derecho del árbol con la divinidad, aparecen dirigidas a ella una ardilla (Sciurus "ardilla de los algarrobales" y posiblemente un papagayo (Aratinga "papagayo serrano") o quizás guacamayo, y a la izquierda e inferior del árbol (muros mayores de Cao Viejo y la Luna y muro menor de Cao Viejo), se observa un pez life ((Trichomycterus sp.) y un batracio asociado a flores de loto. Debe decirse que el guacamayo ha sido reconocido por los Cañaris como uno de los portadores en los orígenes de la humanidad (Molina 1959 [1575]: 15, 16).

Hacia el lado izquierdo e inferior de la deidad del árbol, se registra un agrupamiento de seres animales y vegetales, conjunto que, como se observa, están delimitados por el personaje con corona de tipo estelar, en un caso (derecha) parado de frente con porra y escudo, y en el otro caso colocado en posición felina o supina con los brazos levantados, al parecer cogiendo un disco. Constituyen representaciones de la flora y fauna del litoral costeño, ampliamente conocidas en las pictografías de la cerámica: langostino magnificado, life, garza picando un pez life, caracol terrestre, batracio, un ave no identificada en el lado izquierdo del life y una escena completa de dos zorros enfrentados, macho y hembra, en medio de los cuales aparece una achupalla (Tillandsia s.p.) floreciendo y rodeado de figuras estelares y de flores de loto.

Definitivamente, aquí hay una integración de elementos que culminan con la creación y forman parte del mar, el río y las albuferas que correspondían al ecosistema costero, especialmente, en esos tiempos, al entorno natural del Complejo El Brujo. Rafael Larco (1938: 95-96) resalta en las pictografías de la cerámica moche la presencia de flora y fauna de ciénagas y lagunas cercanas a la orilla del mar, donde al margen de las especies identificadas en los murales, aparece la garza atrapando peces. Pero, también, se destaca el ecosistema de lomas y medios desérticos al pie de la montañas representado por los zorros enfrentados asociados a una Tillandsia o en otros casos a plantas del interior de los valles costeños (ver Donann y McClelland 1999: 102, fig. 4.51; 121, fig. 4.86)(figs. 64-65).

El zorro (Lycalopex sechurae), entre los animales conocidos, representa una de las figuras más destacadas en la iconografía moche. Es representado con naturalidad en ceramios escultóricos (Larco 


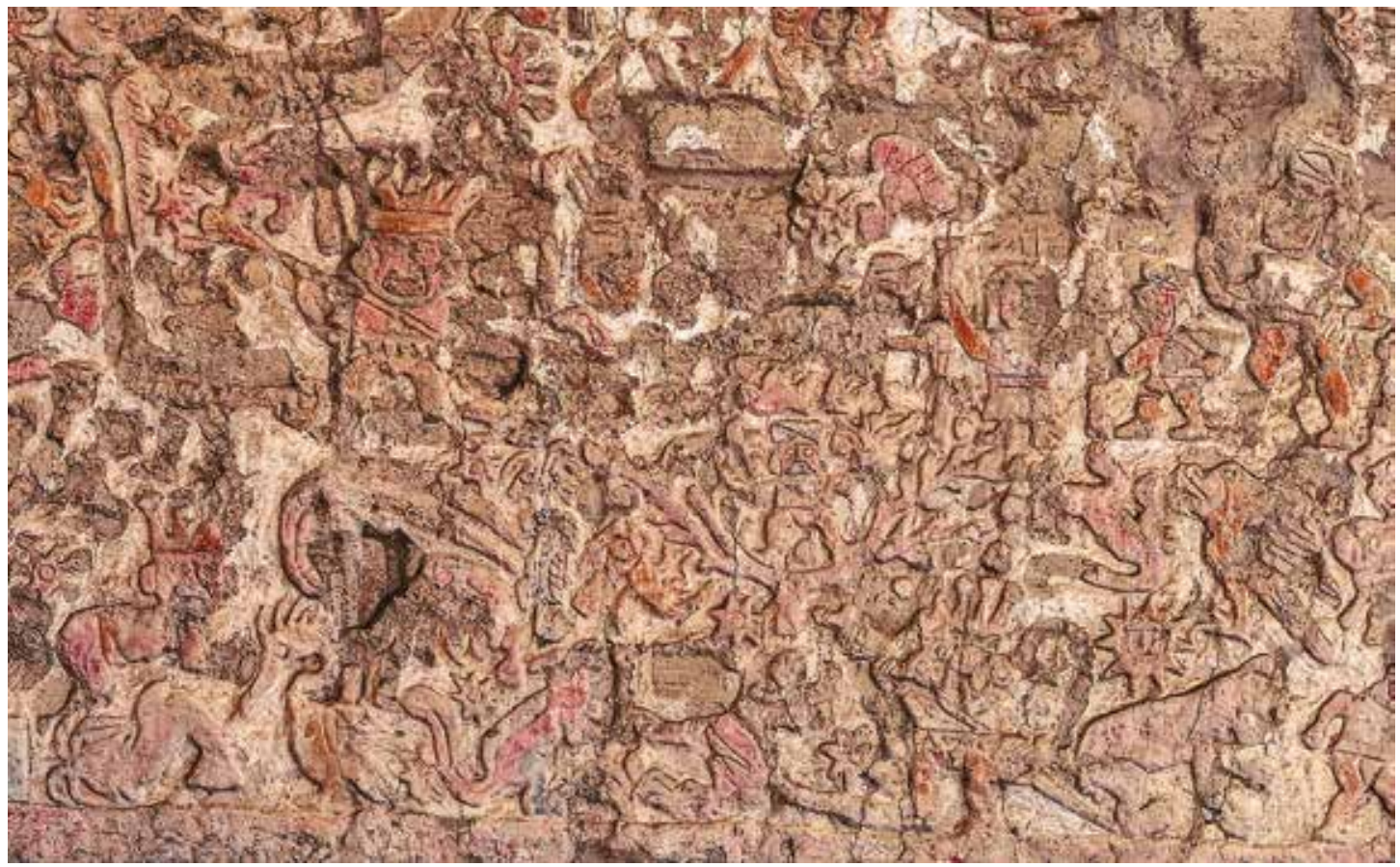

Fig. 58. Divinidades fertilizadoras en el muro menor de la Huaca Cao Viejo. (Foto de Luis De La Vega).

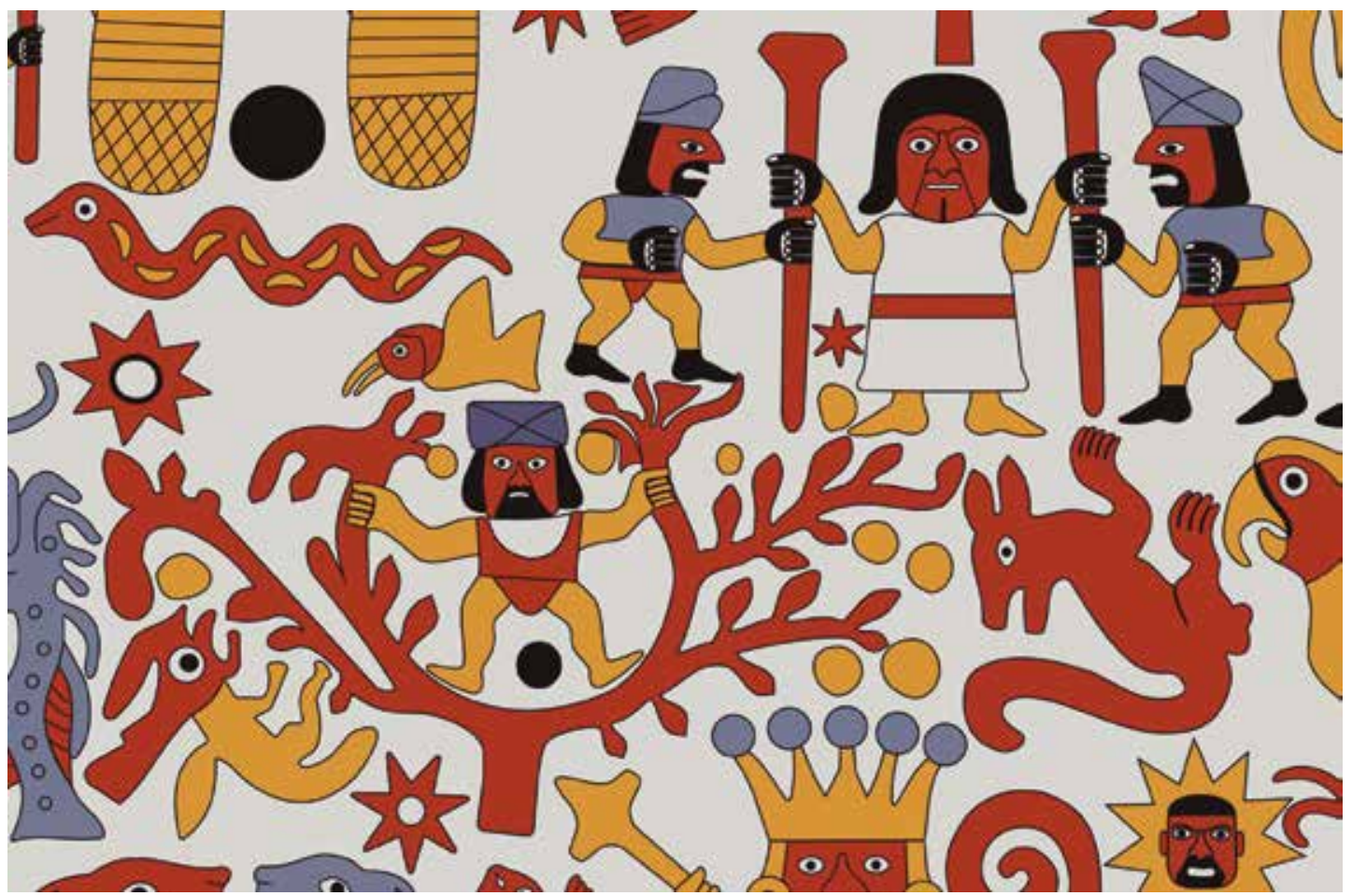




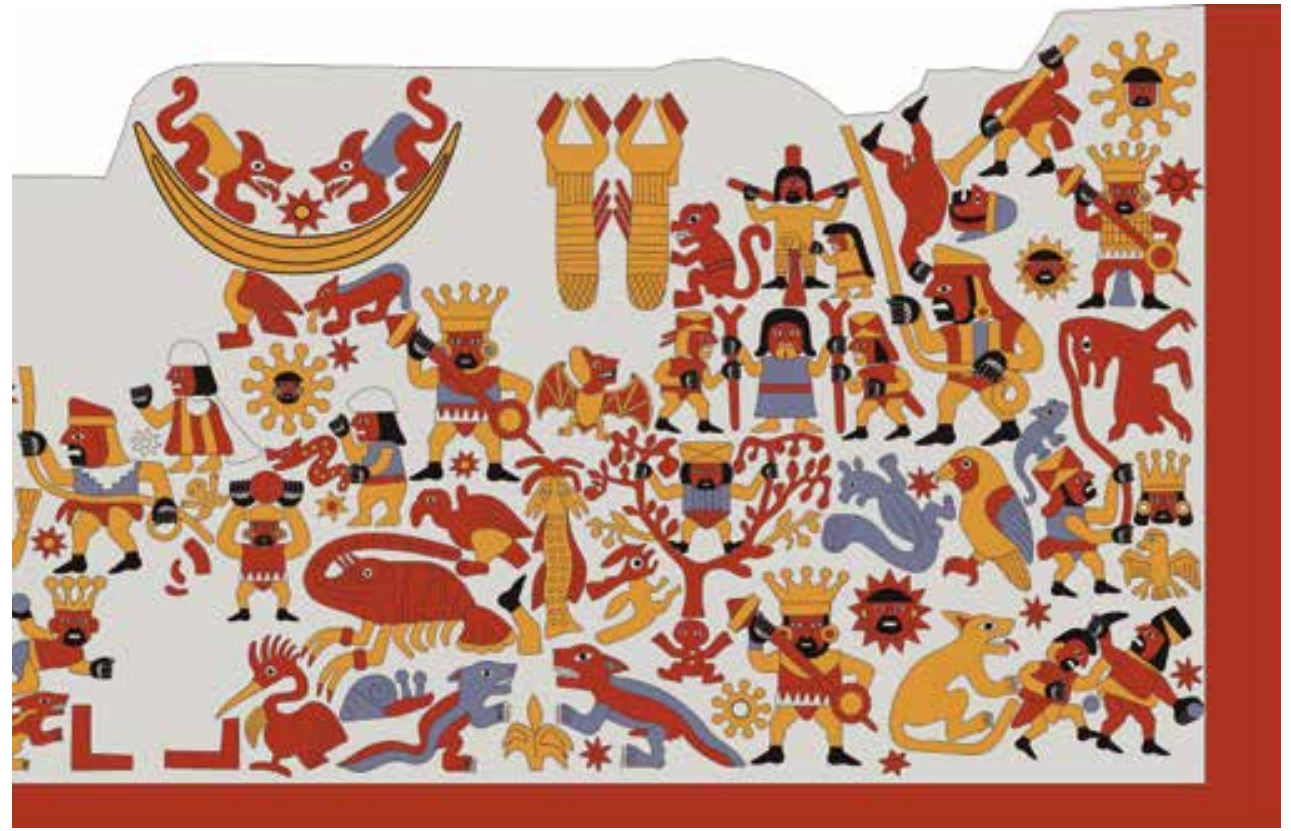

Fig. 60. Motivos vinculados con las divinidades fertilizadoras y su contexto. Muro mayor de la Huaca Cao Viejo (ilustración de Luis De La Vega).

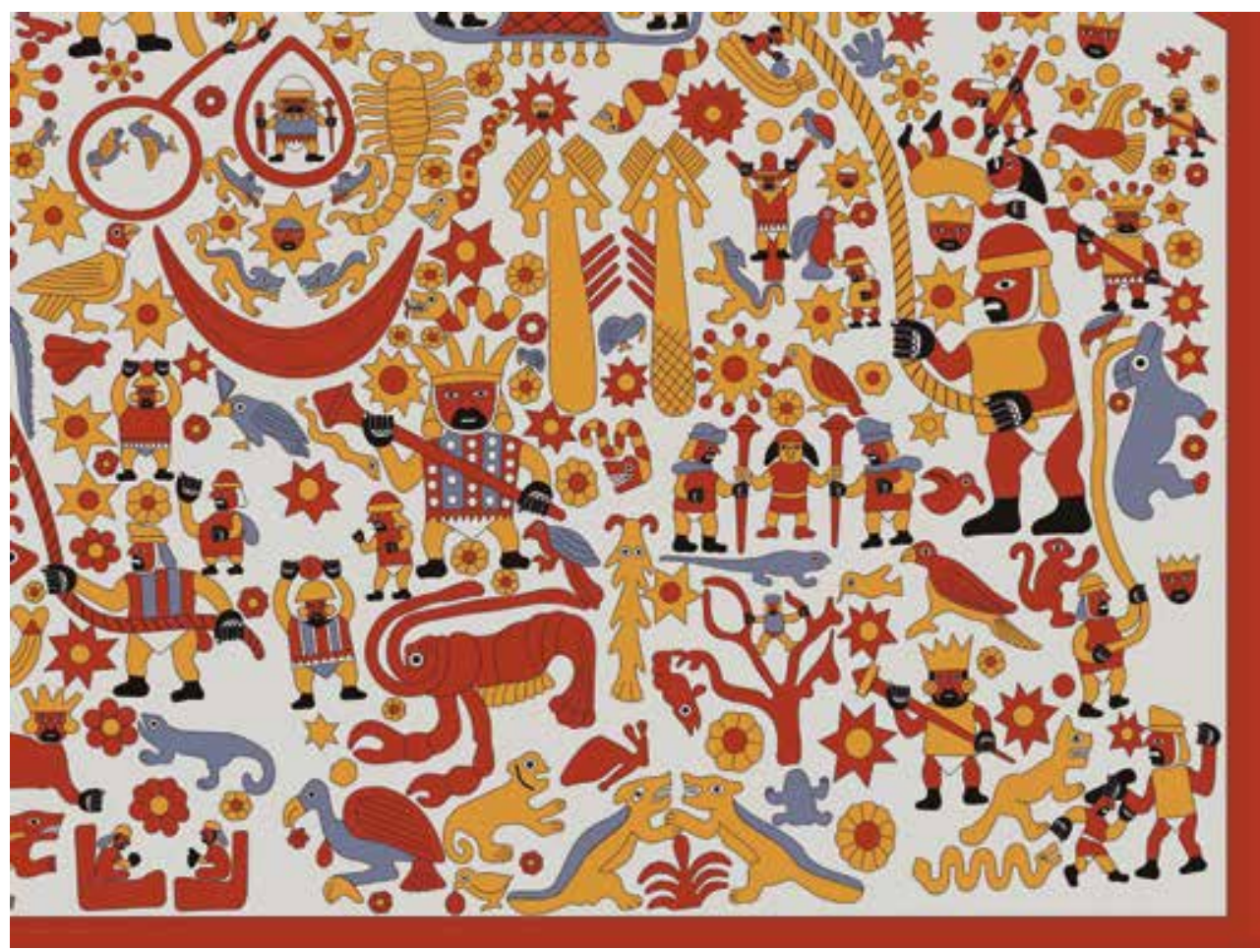

Fig. 61. Motivos asociados a las divinidades fertilizadoras y su contexto. Muro mayor de la Huaca de la Luna (ilustración de Luis De La Vega). 


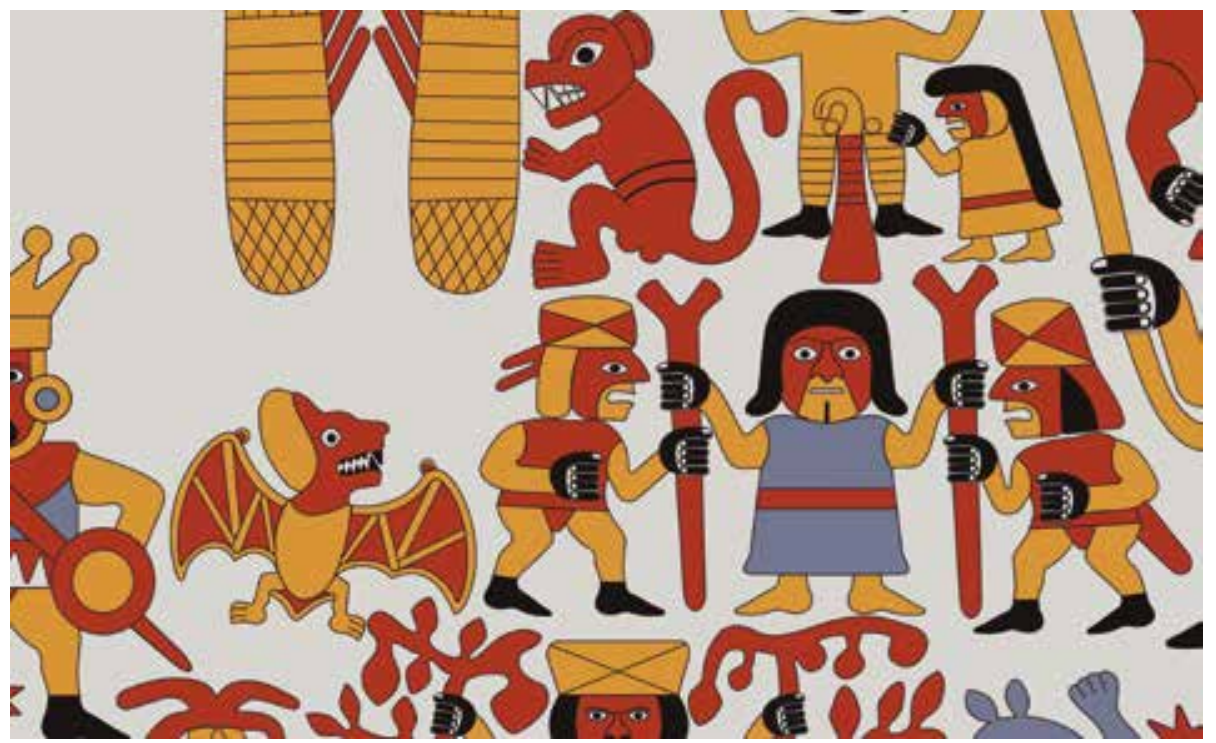

Fig. 62. La figura de un murciélago orientado hacia la divinidad femenina fertilizadora. Muro mayor de la Huaca Cao Viejo (ilustración de Luis De La Vega).

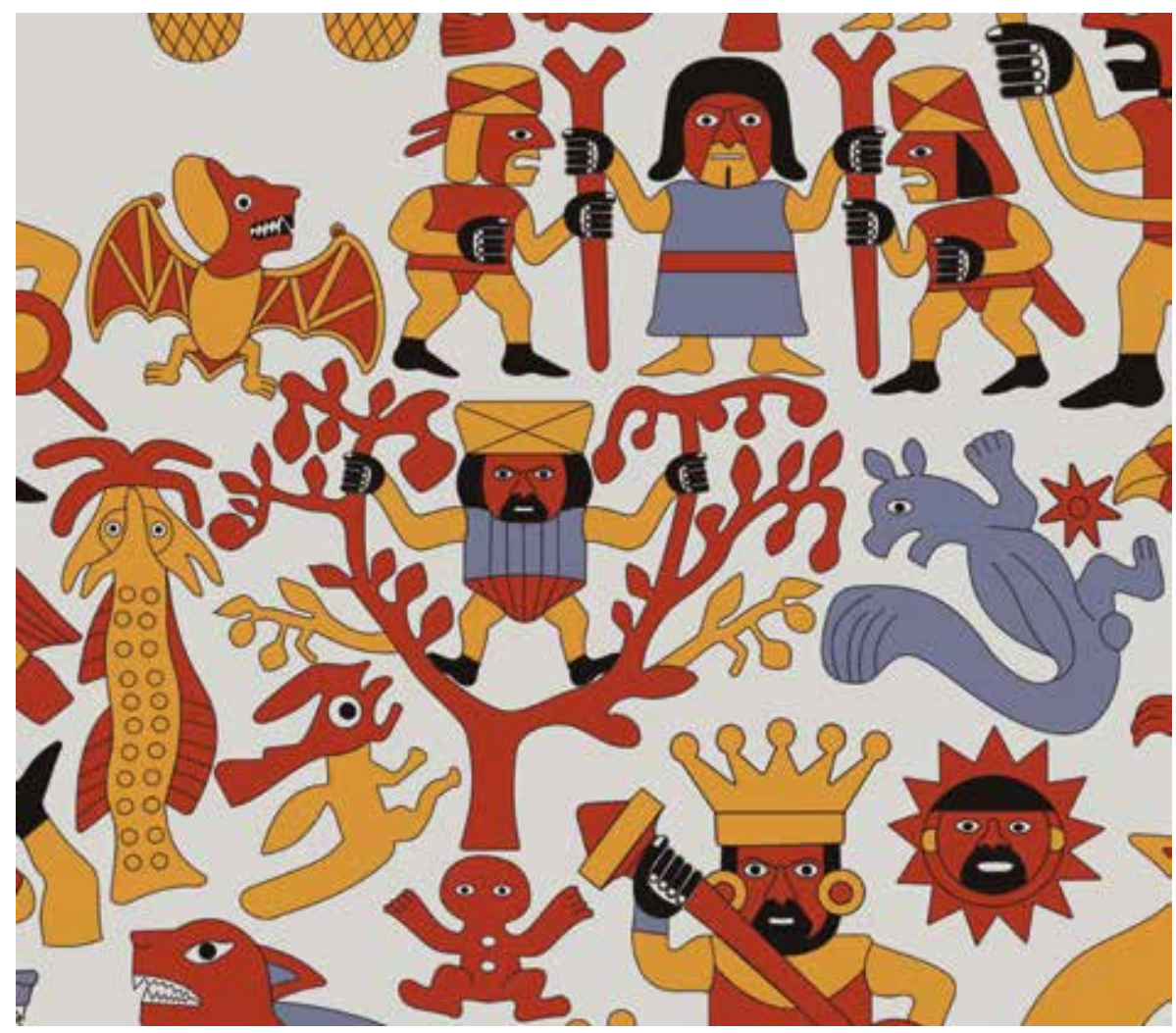

Fig. 63. La divinidad masculina fertilizadora asociada a un ecosistema litoral. Muro mayor de la Huaca Cao Viejo (ilustración de Luis De La Vega). 
1938-39:Fig. 64), así como en las pinturas de manera realista y/o caracterizando a personajes antropomorfos en acciones ceremoniales. El zorro, así como el venado, han sido también cazados. Está presente en las escenas de sacrificio de montaña (fig. 66), como también aparece en la parte superior del techo de un recinto ceremonial en la escena de la carrera. Se le observa como oficiante antropomorfo, como guerrero portando armas. El zorro antropomorfo aparece en diferentes acciones: como corredor ritual en la escena de captura de objetos rebeldes, en la escena del juego adivinatorio de pallares (Larco 1939: Figs. 172 y 173) y en la escena de Badminton ceremonial. En otros casos, en la iconografía no aparecen zorros en la misma posición, sino un felino antropomorfo y un venado (fig. 67). Finalmente, según informaciones generales, en forma especial se observan a zorros parados danzando en círculo cuando hay luna llena, así como vemos en el mural a dos zorros parados en medio de una cactácea.

\section{La Dimension Terrenal y Estelar del Campo Inferior}

Este campo se encuentra por debajo de la soga unida al perro viringo en el lado izquierdo de los murales mayores de Cao y la Luna y en el mural menor de Cao, y ocurre lo contrario en el mural menor de la Luna, donde casi no aparece. Aquí hay un conjunto de escenas con algunas diferencias en la ubicación de los motivos y el agregado de otras figuras no tan significativas en los tres murales anteriormente mencionados.

Una mirada contextual de este campo nos permite indicar que no hay un orden definido en la presentación de las imágenes o motivos. Se observan escenas de rituales de propiciación, rituales de sacrificios humanos, rituales de expiación, escenas de navegación, y todos los seres estelares de la bóveda celeste, que representa una parte de los que aparecen en el campo central y que tienen que ver con el mito de creación de los seres vivos. En suma, tengo la impresión que en este campo se recrean los rituales que practicaban los Moche de acuerdo a las estaciones y cómo éstos tienen correspondencia con el cielo estelar y las entidades que sustentan el mundo terrenal (fig. 68).

\section{Ritos de Sacrificios Humanos para Propiciar el Mundo Doméstico}

En los murales mayores de la Luna y Cao Viejo, hay dos escenas de oficiantes con los brazos abiertos o levantados, que se encuentran sobre estructuras arquitectónicas escalonadas, mientras que en el mural menor de Cao Viejo, hay solo una escena con dos oficiantes enfrentados, uno que levanta los brazos y otro que, aparentemente, inhala a través de un tubo, quizás rapé, algún tipo de sustancia psicoactiva. Esta escena tiene comparación con una actividad ritual en la iconografía moche, ofrecida por oficiantes que consumen coca, hacen gestos e invocan a las divinidades del cielo para pedir agua o lluvia, porque sobre ellos aparece la Vía Láctea con un cielo estrellado en forma de puntos similares a los puntos que se encuentran distribuidos en los murales en estudio (ver Donnan y MClelland 1999: 84, fig. 4.19; 124, fig. 4.90) (fig. 69).

En el muro menor de la Huaca Cao Viejo se distingue posiblemente dos escenas concatenadas: por un lado, una escena de un buitre antropomorfo que acecha a un personaje muerto echado en el suelo, escena similar que en el muro mayor de la Luna no aparece en la misma posición y ya no se trata de un buitre, sino más bien de un cóndor que aparece sobre el cuerpo de un hombre echado en el suelo; y por otro lado, aparece en el muro de Cao un personaje que, al parecer, coge con el brazo levantado una pierna humana, acompañado de un felino, escena que no se registra en el muro mayor de la Luna, o simplemente no se observa bien por su parcial destrucción (fig. 70). Esta escena hace recordar a un hallazgo de brazos humanos cercenados con soguillas en la muñeca, encontrados en la plaza ceremonial de la Huaca Cao Viejo, además del cuerpo de una adolescente con la ausencia del 
fémur en la extremidad inferior izquierdo. Estos restos fueron colocados dentro de una fosa grande y estuvieron cubiertas con varias capas de adobes, rito ocurrido después de un fenómeno pluvial (Franco et. al. 1994b: 119-122). En el mismo lugar donde fueron encontrados estos restos, pero a una mayor profundidad, se halló el esqueleto completo de un gallinazo enterrado $u$ ofrendado que debe tener alguna vinculación con este tipo de ritos. Asimismo, restos humanos con faltantes de algunas partes del cuerpo, fueron también encontrados en la plataforma superior de la Huaca Cao Viejo.

Hay escenas en la iconografía Moche de ritos de sacrificios humanos, particularmente desmembramientos, en donde las extremidades humanas superiores e inferiores atadas con soguillas aparecen flotando (fig. 71). Este rito, como se advierte en las imágenes, están a cargo de mujeres sacerdotisas vestidas de negro y con cinturón blanco, encabezado por una mujer de mayor jerarquía que está también vestida de negro, sentada sobre un trono escalonado bajo una cubierta. Este rito hace recordar a las mismas mujeres vestidas de negro que aparecen en el "tema de la carrera" asociadas a un episodio previo al sacrificio humano, donde estas mujeres se antropomorfizan en el mundo subterráneo, asistiendo o revitalizando a los hombres que fueron sacrificados. En la escena arriba descrita, hay un cántaro con soguilla en el cuello y una botella de cerámica asa estribo (ver Kutscher 1983, figs. 120.1-2; Donnan y Mc Clelland 1999: 121, fig. 4.85).El escenario arquitectónico es sin dudas la parte alta de un templo donde se realiza esta práctica de sacrificio humano.

Por muchos años estuve tratando de comprender por qué aparecen muchos restos humanos incompletos y enterrados en los espacios ceremoniales de los templos Moche, hasta que por fin, creo, encontré una explicación congruente con estas evidencias, en el sentido que estas prácticas tienen relación con ritos de sacrificio asociados a una "siembra simbólica" de restos humanos, por esa razón, aparecen enterrados en los espacios ceremoniales de los templos, precisamente con el fin de propiciar la reproducción de los alimentos en el mundo doméstico. Y para tener un mayor elemento de juicio, citaré una narración de un mito costeño comentado por María Rostworowski (1986: 43-44), referido a la lucha mítica entre las deidades de Vichama y Pachacámac. Según el mito, en un primer episodio, Pachacámac descuartiza al hermano de Vichama, hijo del Sol, y sus restos son sembrados en la tierra, se dice que: de los dientes brotaron granos de maíz; de los huesos brotaron yucas y del resto de su cuerpo brotaron pepinos, pacaes y demás frutos. Y en un segundo episodio, Pachacámac sacrifica a la madre de Vichama y sus restos fueron devorados por los buitres. Esos ritos de sacrificio o de purificación como señala Hocquenghem (1987), estarían vinculados con la restauración del orden, quizás realizados durante el equinoccio de primavera o antes, en el que los días son propicios para las ofrendas (pagos) y los sacrificios cuando la "tierra está abierta".

En el muro mayor de Huaca de la Luna, aparecen un conjunto de imágenes sin ningún orden, tanto que yo diría que es casi la repetición de las escenas que aparecen en todo el lado derecho del huevo cósmico y la Luna nueva en creciente, aparecen por ejemplo: figuras estelares en gran número, al parecer los escorpiones en nacimiento, felinos enfrentados, seres estelares antropomorfos, raya, life, serpientes, flor de loto, un árbol con un gallinazo sobre la cúpula de un árbol, una escena de navegación y el infaltable personaje magnificado con corona de tipo estelar.

En el caso del muro menor y parcialmente en el muro mayor de Huaca Cao Viejo, se observa una escena de navegación, en el que participan dos personajes míticos sobre una balsa, acompañados por una estrella. Y sobre esta escena, se aprecia la figura de un ciempiés con movimiento hacia la derecha. Las representaciones de un alacrán y ciempiés en los murales de la Huaca Cao Viejo juegan un papel importante relacionado con el mundo celestial, especialmente el ciempiés asociado a la Vía Láctea, es decir al cielo nocturno. Para Golte (1994:71), el alacrán, el cangrejo, el ciempiés, simbolizan al cielo nocturno o Vía Láctea que son vistos como generadores de plantas. 


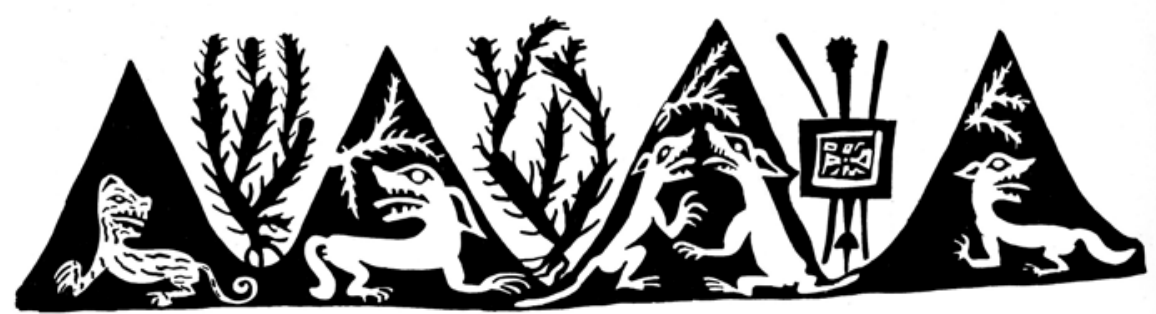

Fig. 64. Felinos en un ecosistema desértico costeño en la iconografía Moche

(Tomado de Donnan y McClelland 1999).

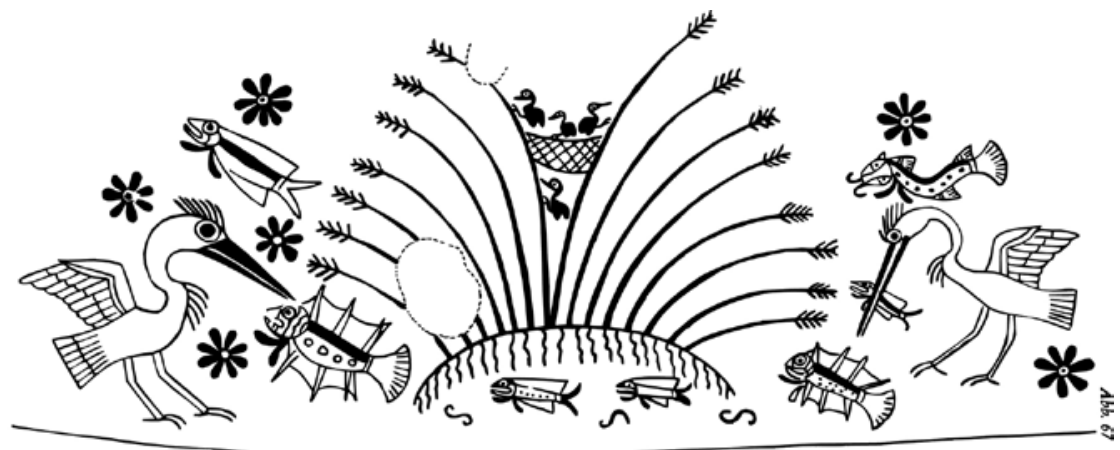

Fig. 65. Ecosistema de humedales en la iconografía Moche (Tomado de Hocquenghem 1987).

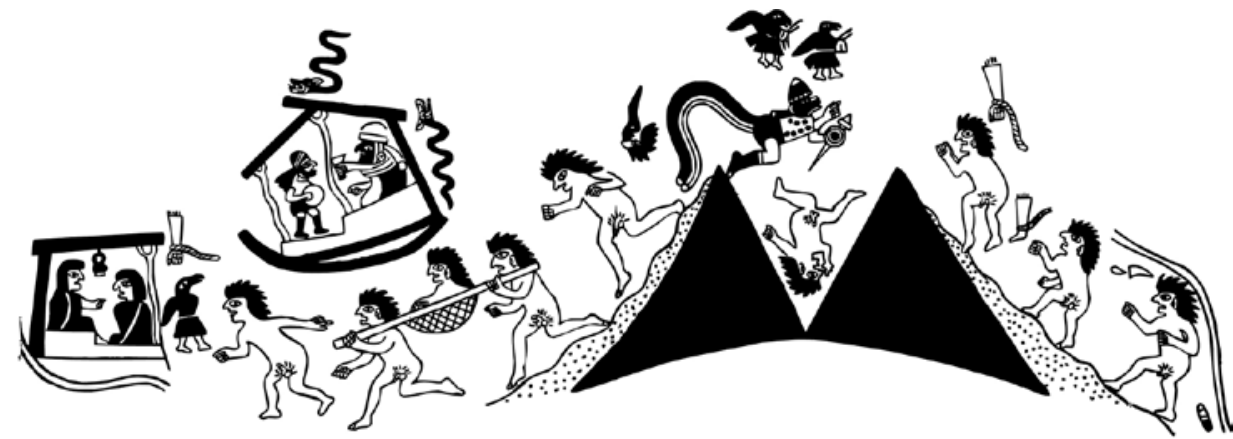

Fig. 66. Escena de la carrera asociado a ritos de sacrificio humano (Tomado de Kutscher 1983).

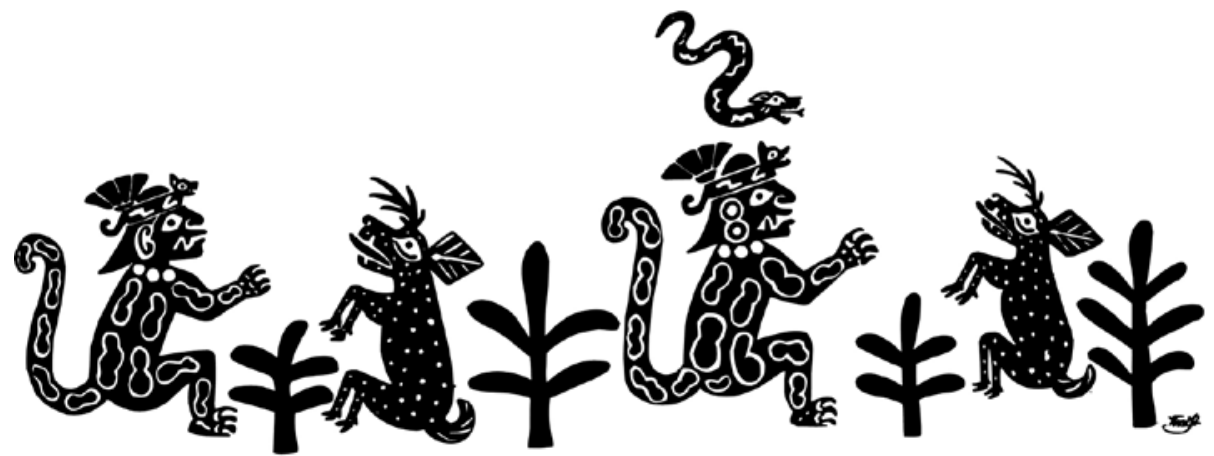

Fig. 67. Felino antropomorfo y venado en la iconografía Moche Tomado de Donnan y McClelland 1999). 


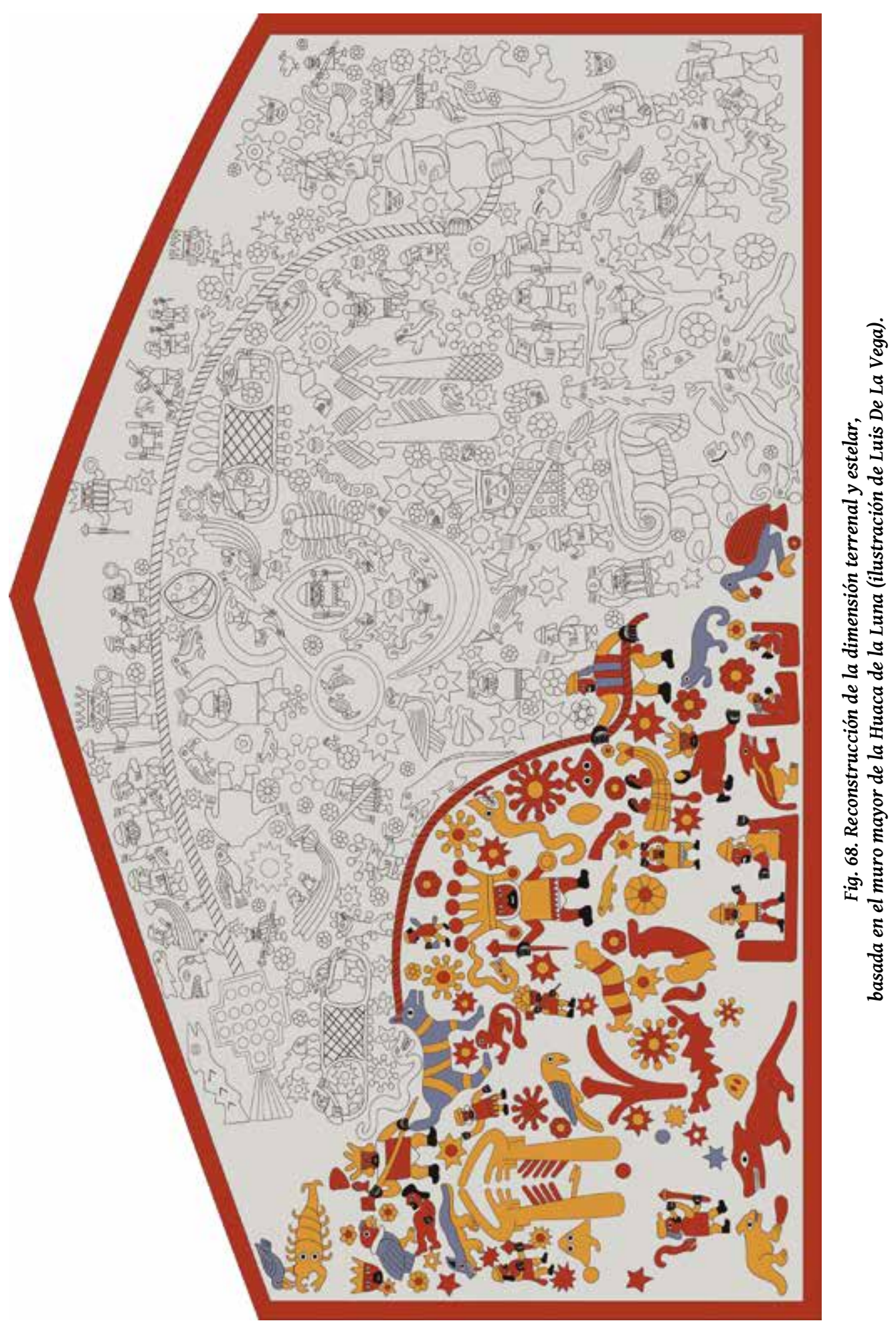




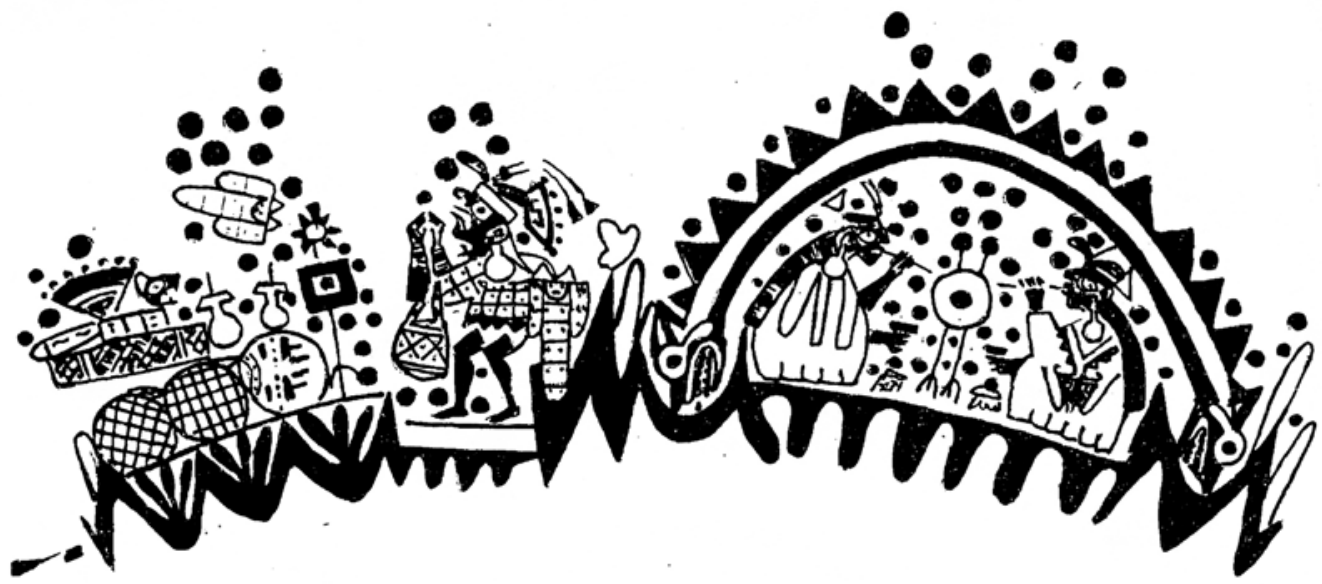

Fig. 69. Escena de ritos chamánicos en la iconografía Moche (Tomado de Hocquenghem 1987).

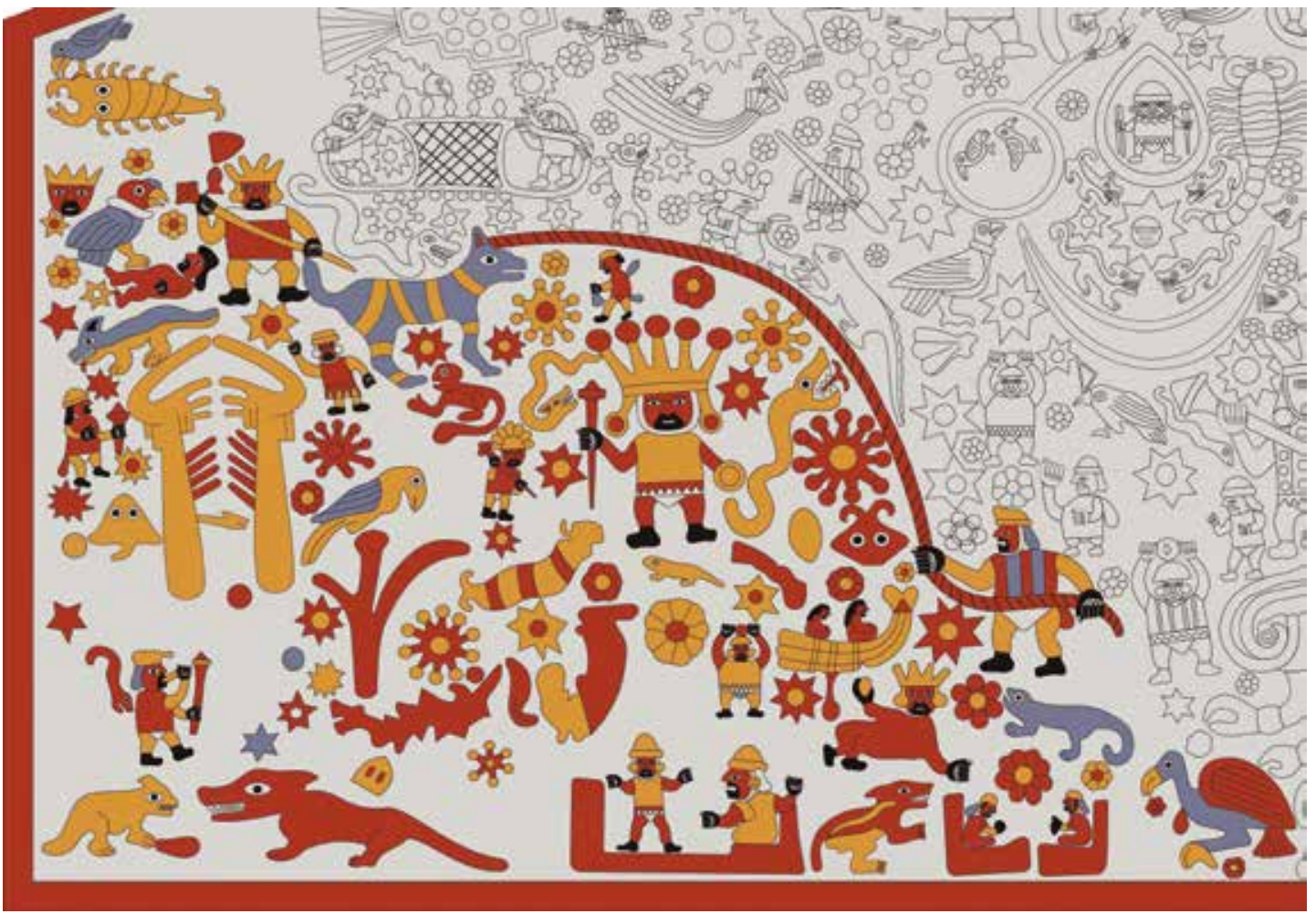

Fig. 70. Reconstrucción de las escenas o ritos en el mundo terrenal y estelar, una dicotomía. Muro mayor de la Huaca de la Luna. (Ilustración de Luis De La Vega). 


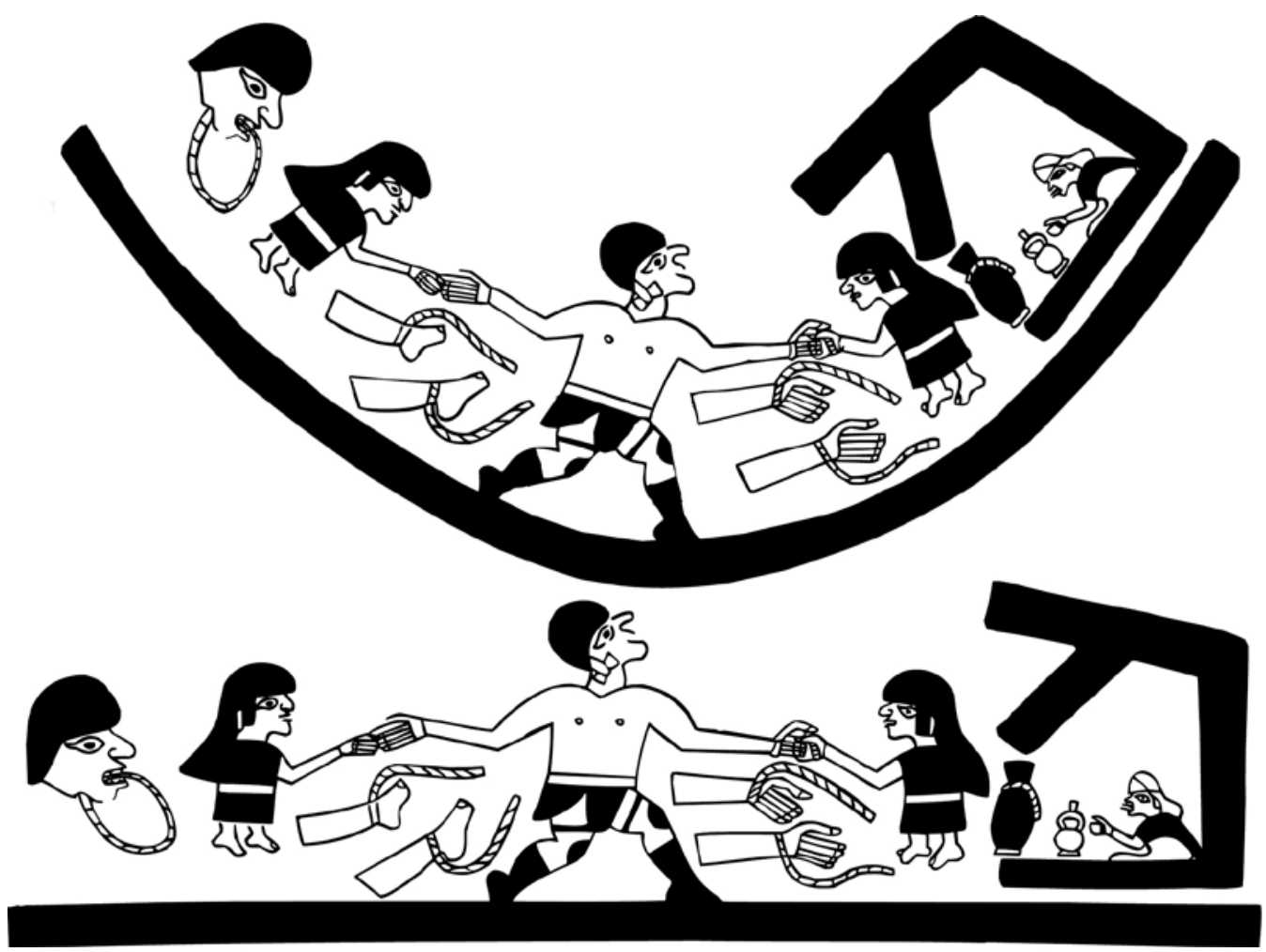

Fig. 71. Escena de desmembramientos humanos en la iconografía moche (Tomado de Kutscher 1983).

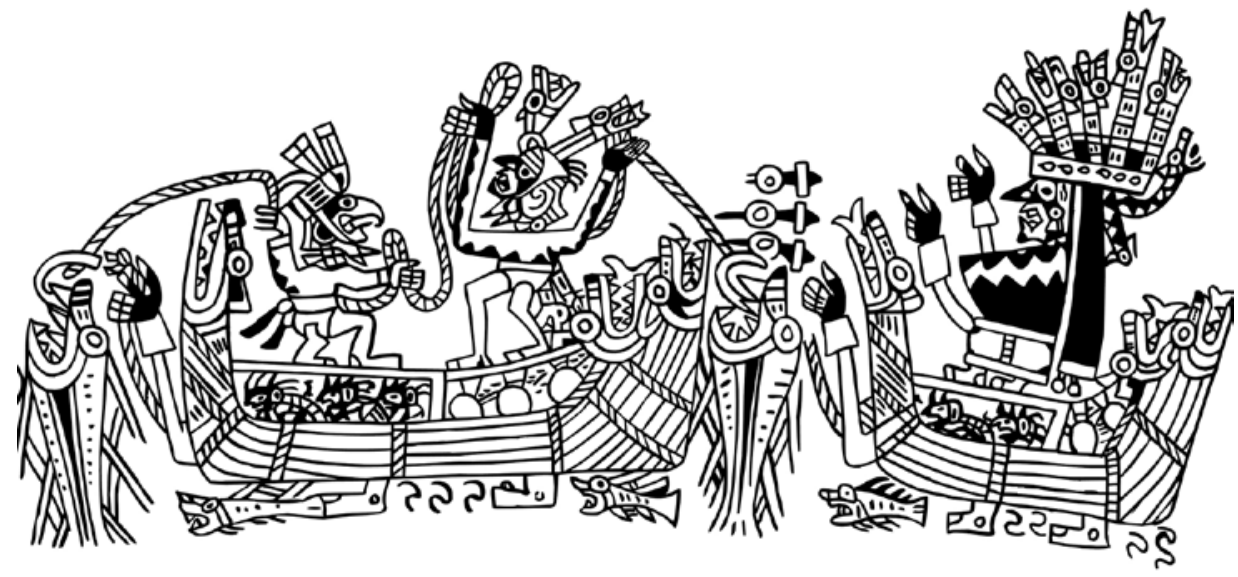

Fig. 72. Escena de travesía marina conduciendo prisioneros en la iconografía moche (Tomado de Kutscher 1983). 
La escena de navegación o "travesía por el océano" de acuerdo a Hocquenghem (1987:127), indicarían actividades y fenómenos celestiales relacionados con la propiciación del mundo marino; probablemente simboliza el pasaje de la luna sobre el pacífico, al establecerse una relación de semejanza entre las barcas marinas y la luna. Según la misma autora, se dice que actualmente en los Andes, las almas de los muertos deben atravesar una extensión de agua que se encuentra en dirección de la puesta del Sol, antes de poder alcanzar el lugar de descanso, que es también el lugar del origen (fig. 72 ).

En suma, este campo con imágenes agrupadas, a veces fáciles de entender, otras difíciles de comprender, tienen definitivamente relación con una narración mítica, en donde se activan escenas de sacrificio, propiciación del mundo doméstico y marino, embarcación marina, entre otros, asociado al cielo nocturno donde viven los seres luminosos proveedores de los alimentos en la tierra y en el mar. Muchas escenas que aparecen fueron necesariamente recreadas en el mundo real.

\section{CONCLUSIONES}

El arte y simbolismo de los murales moche en los últimos 25 años ha aportado información sumamente importante para la comprensión del mensaje simbólico asociado a los espacios ceremoniales de los templos, en especial de las Huacas de Cao Viejo y de la Luna. Recordemos que las explicaciones o interpretaciones del mundo Moche estaban antes basadas únicamente en el estudio iconográfico de la cerámica, que sin dudas también aportó mucho para entender varios episodios de la vida religiosa de esta cultura costeña.

La iconografía constituye un documento gráfico excepcional que permite acercarnos a la explicación del sistema religioso de la época, expresado en un número limitado de escenas que trasmiten un discurso fragmentado de la historia mítica de los Moche (cosmología y cosmogonía), que a través de la comprensión del mundo mítico o fabuloso se recreaban episodios que formaban parte de un calendario mítico ceremonial, algunas bastante comprensivas que han sido explicadas de manera muy general por Ann Marie Hocquenghem en 1987.

Ahora entendemos que, ante la ausencia de un altar mayor o estructura arquitectónica de gran tamaño al interior de la plaza ceremonial de los templos mayores, algo así como existía en las plazas de peregrinos de la época inca, el recinto esquinero decorado se constituía en un espacio sacro. Este sector fue el foco de las actividades ceremoniales públicas, vinculadas con los ritos de propiciación del mundo doméstico y en particular de la ceremonia de presentación de los prisioneros derrotados en la batalla ritual, que fue un episodio previo al sacrificio de estos hombres que culminaban su vida en la parte alta del templo.

Dentro del contexto arquitectónico de las Huacas de Cao Viejo y la Luna, los Temas Complejos son considerados como uno de los descubrimientos más relevantes de la arquitectura religiosa Moche de los últimos tiempos, por su contenido y complejidad, y representa quizás el único arte mural complejo en barro que se conoce hasta el momento en América Andina en general.

Este escenario arquitectónico fue muy bello, porque mostraba los dos murales con Temas Complejos (muro mayor y menor) con un cielo raso policromado, además del frente oeste decorado del recinto esquinero, y qué decir de las representaciones que estaban presentes en cada una de las terrazas del frente principal del templo, que seguramente con sólo mirarlas, habría causado un gran impacto visual y en consecuencia un gran regocijo para quienes llegaban y se congregaban en este espacio mayor y abierto para asistir a los ritos o ceremonias.

La temporalidad de los Temas Complejos corresponde a la última fase de construcción del templo, en correspondencia con la evolución de la cerámica Moche IV-V, aún, cuando, la presencia de cerá- 
mica de la fase $\mathrm{V}$ en este sitio, no aparece mucho. Sin embargo, hay otro elemento diagnóstico en la arquitectura que respalda la temporalidad tardía de los Temas Complejos, es precisamente la presencia de adobes con marca de fabricante, que aparecen en masa dentro de las dos últimas fases tardías de construcción. Asimismo, la nueva ideología de poder expresada en los dos murales se impone como una respuesta a la crisis climática que habían vivido anteriormente, al final del funcionamiento del tercer edificio, que indujo al sacerdocio a incrementar las actividades rituales: sacrificios humanos, marcas simbólicas en el piso de la plaza ceremonial, etc., con el objetivo de reestructurar del orden de la sociedad.

Después de una revaluación de los Temas Complejos, sobre todo con base en la información que presenta ahora el muro mayor de la Huaca de la Luna, y en menor medida el muro menor de la Huaca Cao Viejo, se puede distinguir tres campos definidos por las sogas cogidas por personajes míticos: El campo superior unido al campo inferior, vinculado a ritos de combate, suplicios, ofrendas y de pasaje hacia el mundo de arriba o estelar; el campo central relacionado con el mito de creación, en el que se le da énfasis al numen, el hueco cósmico y la Luna como referentes principales y universales que se relacionan directamente con todos los seres luminares, vivientes y actividades asociadas a las subsistencias del mundo agrícola y marino; y el campo inferior donde se establece un sistema de ritos propiciatorios vinculados con las subsistencias y su relación con el cielo estelar, constelaciones y pléyades. Todo en conjunto, representa una especie de calendario mítico ceremonial que en los ritos respondía a su recreación en el mundo terrenal de los moche.

Una de las imágenes muy importantes que acompaña a las estructuras narrativas generales o contextualizadas es el "personaje con corona de tipo estelar", casi siempre magnificado, y que aparece en más de siete oportunidades, dando la impresión de una rueda calendárica establecida por la estrella Venus o la pléyade de las siete cabrillas, que, como se ha visto, da inicio al calendario anual ceremonial de los pobladores de la costa norte al inicio del equinoccio de junio. Este personaje tiene atributos de guerrero, asumiendo quizás una naturaleza divina y mitológica por la manera como está distribuido y por su relación directa con las escenas del mundo fabuloso así como las del mundo terrenal doméstico.

Se distingue una categorización de personajes, siendo el grupo más numeroso el de los "oficiantes", con papeles protagónicos en los ritos y/o ceremonias, sean como acólitos o acompañantes de las divinidades, en acciones de propiciación, de pasaje, ofrendas o sacrificio. Uno de los atributos de estos personajes son los tocados sobre la cabeza, similar al tocado de la divinidad fertilizadora del árbol, que seguramente remite a un emblema ancestral de jerarquía. Otro tipo de tocado son unos penachos que se asocia a los personajes de las escenas de navegación.

La presencia de animales en el plano mitológico y asociado al discurso de las divinidades o ancestros mayores es de vital importancia. Desempeñan papeles simbólicos, actúan a veces como indicadores ambientales o temporales de las actividades míticas en las que aparecen. Estos animales pueden resumirse en felino, perro, venado, zorro, iguana, murciélago, escorpión, gallinazo, búho, lagartija, serpiente, mono, garza, pez raya, pez life, langostino, ciempiés, aves terrestres, aves marinas, batracio y caracol. Y en cuanto a flora se identifican la flor de loto, la achupalla, el zapote y las flores flotantes de laguna.

Sostengo, finalmente, que la información iconográfica de los Temas Complejos de las Huacas de Cao Viejo y la Luna se relacionan con un calendario mítico-ceremonial, que funcionaba en torno a los ciclos lunares, pléyades o constelaciones, y que permitía ordenar el sistema ideológico moche. Este discurso simbólico de naturaleza mítica, era el principal referente para la recreación periódica de los ritos y ceremonias (ritos agrícolas y marinos) para fortalecer el poder ideológico de la elite moche. En 
suma, y de acuerdo con Hocquenghem (1987), encontramos en los murales muchos episodios vinculados con: "La reproducción", "reestructuración", "propiciación del mundo doméstico", "legado de los antepasados”, "sacrificio", “expiación”, “Iniciación” e "inversión del orden”.

\section{AGRADECIMIENTOS}

Quiero agradecer de manera muy especial a la Fundación Wiese que se encarga de ejecutar el Programa El Brujo durante 26 años en beneficio de la cultura del país. A todos mis colegas y colaboradores del Proyecto Arqueológico El Brujo, en especial a Juan Vilela con quién iniciamos estos estudios hace muchos años. Mi gratitud y agradecimiento al Dr. Guillermo Wiese de Osma (+), al arqueólogo Antonio Murga (+). A César Gálvez Mora del Ministerio de Cultura, con quien compartimos todo el proceso de estudios en la Huaca Cao Viejo. Mi agradecimiento al Dr. Luis Millones por algunas revisiones acertadas y al Dr. Jorge Silva Sifuentes por sus valiosos comentarios sugeridos; a Clene Salles por las sugerencias en el estilo del texto. Finalmente, mi gratitud y agradecimiento a todos mis colegas y amigos que de alguna u otra manera contribuyeron en el proceso de esta investigación.

\section{BibliografíA}

ALCINA FRANCH, José

1987 Arte Precolombino. Historia del Arte Hispanoamericano 1. Editorial Alhambra S.A, pp. 243, Madrid.

ARRIAGA, Joseph

1920 [1621] Extirpación de la idolatría en el Perú. Colección de libros y documentos referentes a la historia del Perú. Lima.

AVILA, Francisco de

1966 [1598?] Dioses y Hombres de Huarochirí. Traducción de José María Arguedas, Instituto de Estudios Peruanos, Lima.

BAWDEN, Garth

1994 "La paradoja estructural: La cultura Moche como ideología política”. En: Moche: Propuestas y Perspectivas. (S. Uceda y E. Mujica, editores): 389-412. Actas del Primer Coloquio Sobre la Cultura Moche, 1993. Travaux de L'Institud Francais D’Etudes Andines, Lima.

BENSON, Elizabeth P.

1972 The Mochica, A Culture of Peru, Art and Civilizations of Indian America. Michael Coe, ed. Praeger Publishers, New York, Washington.

BEREZKIN, Yuri E.

1980 "An identification of anthropomorphic mythological personages in Moche representations". En: Ñawpa Pacha 18: 1-26. Institute of Andean Studies, Berkeley.

BONAVIA, Duccio

1985 Mural Painting in Ancient Perú. Indian University Press Bloominton. 
BOURGET, Steve

1996 "Los raptores de almas: prácticas funerarias en la iconografía mochica". En: Al Final del Camino (L. Millones y M. Lemlij, editores): 37-50, Fondo Editorial SIDEA, Lima.

BURGUER, Richard L.

1992 Chavín and the origins of Chavín civilization. Thames and Hudson Ltd., London.

2011 "What kind of hallucinogenic snuff was used at Chavín de Huántar?, an iconographic identification”. En: Ñawpa Pacha: Journal of Andean Archaeology, Volume 31, Number 2, pp. 123140.

BRUHNS, Karen

1976 “The moon animal in Northern Peruvian art and cultura. Ñaupa Pacha 14:21-39. Berkeley, Institute of Andean Studies.

CALANCHA, Antonio de

1976-78[1638] Corónica Moralizadora de la Orden de San Agustín en el Perú. Edición de Ignacio Prado Pastor, 6 T., Lima.

CARRION CACHOT, Rebeca

1959 La religión en el antiguo Perú. Talleres Gráficos de Tipografía Peruana, Lima.

CASTIGLIONI, Arturo

1987 Encantamiento y Magia. Fondo de Cultura Económica, pp. 392, México.

CASTILLO B., Luis Jaime

1989 Personajes míticos, escenas y narraciones en la iconografía mochica. Fondo Editorial Pontificia Universidad Católica del Perú, pp. 360, Lima.

COBO, Bernabé S.J.

1956 [1653] Historia del Nuevo Mundo. Biblioteca de Autores Españoles, Atlas, Madrid.

COOK, Anita

1994 Wari y Tiwanaku: Entre el estilo y la imagen. Fondo Editorial Pontifica Universidad Católica del Perú, pp. 344, Lima.

CORDY-COLLINS Alana

1992 "Archaism or tradition?: The decapitation theme in Cupisnique and Moche Iconography". En: American Antiquity, № 3, Washington.

2003 "El mundo Moche al empezar el siglo VIII: Transiciones e influencias". En: Moche: hacia el final del milenio (S. Uceda y E. Mujica, editores): 229-246. Tomo II. Actas del Segundo Coloquio sobre la Cultura Moche (Trujillo, 1 al 7 de agosto de 1999). Universidad Nacional de Trujillo y Pontificia Universidad Católica del Perú, Lima.

DE BOCK, Edward K.

1988 Moche: Gods, Warriors, Priests. SPRUYT, the Netherlands. 
DE BOCK, Edward K.y Tom R. ZUIDEMA

1991 “Coherencia matemática en el arte andino”. En: Los Incas y el Antiguo Perú. 3000 Años de Historia. T. I: 454-463, Madrid.

DOLORIER TORRES, Camilo y Lyda CASAS SALAZAR

2012 “Ritos, Tránsito a lo sagrado y Búsqueda de Equilibrio en el Mundo Moche”. En: Cosmos Moche. Colección enigmas del antiguo Perú. Edición Bilingüe, Editor: Roberto Ochoa Berreteaga, Museo Andrés del Castillo, pp. 139-152.Lima.

DONNAN, Christopher B.

1976 Moche Art and Iconography. UCLA Latin American Center Publications University of California, Los Angeles.

1978 Moche Art of Perú. Pre-Columbian Symbolic Communication. Museum of Cultural History, University of California, Los Angeles.

1979 “La caza del venado en el arte mochica”. En: Revista del Museo Nacional, № 46: 235-251, Lima.

DONNAN, Christopher y Donna MCCLELLAND

1979 “The Burial Theme in Moche Iconography”. Studies in Pre-Columbian Art and Archaeology, 21. Dumbarton Oaks, Washington D.C.

1999 Moche Fineline Painting. UCLA Fowler Museum of Cultural History, Los Angeles, California.

FRANCO, Régulo

2008 “La Señora de Cao". En: Señores de los Reinos de la Luna (Krzysztof Makowski, compilador): 280-287, Banco de Crédito, Colección Arte y Tesoros del Perú, Lima.

2015 “Chamanismo y plantas de poder en el mundo precolombino de la costa norte del Perú". En: Revista Perspectivas Latinoamericanas, El Taki Onqoy, págs. 1-40. Japón.

FRANCO, Régulo y César GÁLVEZ

2003 "Un Ídolo de Madera en un edificio Mochica Temprano de la Huaca Cao Viejo, Complejo El Brujo”. En: Arkinka: 93: 94-105, Lima.

FRANCO, Régulo y Juan VILELA

1999/2000 “El Calendario Mochica en el complejo arqueológico El Brujo". En: Medio de Construcción № 155: 42-48, Lima.

2003a "Aproximaciones al Calendario Ceremonial Mochica del Complejo El Brujo, Valle Chicama”. En: Moche: hacia el final del milenio (S. Uceda y E. Mujica, editores): 383-423. Tomo I. Actas del Segundo Coloquio sobre la Cultura Moche (Trujillo, 1 al 7 de agosto de 1999). Universidad Nacional de Trujillo y Pontificia Universidad Católica del Perú, Lima.

2003b “Iconografía de dos murales del Complejo El Brujo, una aproximación al calendario ceremonial mochica". En: Arqueológicas 26: 73-106, Lima.

2005 El Brujo, El Mundo Mágico Religioso Mochica y el Calendario Ceremonial. Pp. 141, Minka-Perú, Trujillo. 
FRANCO, Régulo; GÁLVEZ, César y Segundo VÁSQUEZ

1994 “Arquitectura y Decoración Mochica en la Huaca Cao Viejo, Complejo El Brujo: Resultados Preliminares". En: Moche: Propuestas y Perspectivas, (S. Uceda y E. Mujica, editores): 147-180. Actas del Primer Coloquio Sobre la Cultura Moche, 1993,Travaux de L'Institud Francais D’Etudes Andines, Lima.

1998 “Un cielo raso moche policromo”. En: Medio de Construcción № 144: 37-42, Lima.

2001 “Graffitis Mochicas en la Huaca Cao Viejo, Complejo El Brujo”. En: Boletín del Instituto Francés de Estudios Andinos, 30 (2): 359-395, Lima.

FRANCO JORDÁN, Régulo, César GÁLVEZ MORA, Segundo VÁSQUEZ SÁNCHEZ y Antonio MURGA CRUZ

1999 "Reposición de un muro mochica con relieves polícromos, Huaca Cao Viejo, complejo El Brujo”. En: Arkinka 43: 82-91, Lima.

GILLIN, John

1947 "Moche: A Peruvian Coastal Community". Smithsonian Institution. Institute of Social Anthropology Publication, № 3, Washington D.C.

GOLTE, Jürgen

1994 Iconos y Narraciones. La reconstrucción de una secuencia de imágenes Moche. Instituto de Estudios Peruanos, págs. 144, Lima.

2009 Moche, Cosmología y Sociedad. Una interpretación iconográfica. Instituto de Estudios peruanos y Centro Bartolomé de las Casas, págs. 473, Cusco.

HOCQUENGHEM, Anne Marie

1987 Iconografía Mochica. Fondo Editorial Pontificia Universidad Católica del Perú, págs. 280, Lima.

2008 "Sacrifices and Ceremonial Calendars in Societies of the Central Andes: A Reconsideration". En: The Art and Archaeology of the Moche, and Ancient Andean Society of the Peruvian North Coast, edited by Steve Boruget and Kimberly L. Jones, pp. 23-42, University of Texas Press Austin.

KUTSCHER, Gerdt

1954 Nord peruanische Keramik. Figurlichverzierte. Gefasse der Fruh-Chimu. Cerámica del Perú Verlag Gebr. Mann, Berlín.

1983 Nord peruanische Gefässmalereien des Moche-Stils. Verlag C.H. Beck, Munich.

LARCO HOYLE, Rafael

1938 Los Mochicas. Tomo 1. Casa Editora La Crónica y Variedades S.A., Lima

1939 Los Mochicas. Tomo 2. Casa Editora La Crónica y Variedades S.A., Lima.

1948 Cronología arqueológica del norte del Perú. Biblioteca del Museo de Arqueología "Rafael Larco Herrera" Hacienda Chiclín, Trujillo.

2001 Los Mochicas. Museo Arqueológico Rafael Larco Herrera (Lima: Metrocolor), 2 T. 
LEON BARANDIARÁN, Augusto

1938 Mitos, Leyendas y Tradiciones Lambayecanas. Contribución al Folklore Peruano. El Club de Autores y Lectores, Lima.

LIESKE, Barbel

1992 "Mythische Erzahlungen in den Gefaßmalereien der altperuanischen Moche-Kultur". Versuch Einer Ikonographischen Rekonstruktion. Bonn: Holos-Verlag.

MACKEY, Carol y Melissa Vogel

2003 “La Luna sobre los Andes: Una revisión del Animal Lunar". En: Moche: hacia el final del milenio (S. Uceda y E. Mujica, editores): 325-342, Tomo I. Actas del Segundo Coloquio sobre la Cultura Moche (Trujillo, 1 al 7 de agosto de 1999). Universidad Nacional de Trujillo y Pontificia Universidad Católica del Perú, Lima.

\section{MAKOWSKI, Krzysztof}

1994 “La figura del Oficiante en la iconografía Mochica: ¿Chamán o Sacerdote?”. En: En el Nombre del Señor, Shamanes, Demonios y Curanderos del Norte del Perú. (L. Millones y M. Lemlij, editores): 52-101. SIDEA, Lima.

1996 "Los Seres Radiantes, el Aguila y el Búho, la imagen de la divinidad en la cultura mochica" En: Imágenes y Mitos. (Krzysztof Makowski, Iván Amaro y Max Hernández): 13-114, Australis S.A., Casa Editorial Fondo Editorial SIDEA, Lima.

2001 "Ritual y narración en la iconografía mochica". Arqueológicas 25: 175-203. Lima, Instituto de Investigaciones Antropológicas, Museo Nacional de Arqueología, Antropología e Historia del Perú, Instituto Nacional de Cultura.

2008 "El rey y el sacerdote”. En: Señores de los reinos de la luna (Krzysztof Makowski, comp.): 77109, Banco de Crédito, colección.

MOLINA, Cristóbal de

1959 [1575] Ritos y Fábulas de los Incas. Ed. Futuro, Buenos Aires.

NARVAÉZ VARGAS, Alfredo

2014 Dioses de Lambayeque, Estudio Introductorio de la Mitología Tardía de la Costa Norte del Perú. Ministerio de Cultura del Perú, Unidad Ejecutora 005/Museo de Sitio de Túcume, págs. 318, Lambayeque, Perú.

\section{PADRES AGUSTINOS}

1992 [1561?] Relación de los Agustinos de Huamachuco. Estudio preliminar y notas de Lucila Castro de Trelles. Fondo Editorial Pontificia Universidad Católica del Perú, Lima.

RICK, John

2011 Chavín de Huántar, protocolo de la investigaciones arqueológicas. Instituto Andino de Estudios Arqueológicos-Sociales, Proyecto de Investigaciones Arqueológicas y Conservación de Chavín de Huantar, Antamina, asociación Ancash Global HeritageFound, págs. 188, Lima. 
ROSTWOROWSKI DE DIEZ CANSECO, María

1981 Recursos naturales renovables y pesca, Siglo XVI y XVII. IEP, Lima.

1986 Estructuras Andinas de Poder. Instituto de Estudios Peruanos, 2da. ed., págs. 202, Lima.

SAKAI, Masato

1998 Reyes, Estrellas y Cerros en Chimor. El proceso de la organización espacial y temporal en Chan Chan. Editorial Horizonte, págs.139.

SANCHEZ GARRAFA, Rodolfo, Camilo DOLORIER TORRES y Lyda CASAS SALAZAR

2012 Cosmos Moche. Colección enigmas del antiguo Perú. Edición Bilingüe, Editor: Roberto Ochoa Berreteaga, Museo Andrés del Castillo, págs. 176. Lima.

SANTA CRUZ PACHACUTI YANQUI SALCAMAYGUA, Joan de

1993 [1613?] Relación de antigüedades deste reyno del Pirú. Estudio etnohistórico y lingüístico de Pierre Duviols y César Itier. Instituto Francés de Estudios Andinos, Centro de Estudios Regionales Andinos "Bartolomé de las Casas", págs.276, Cusco.

SHARON, Douglas

1980 El Chamán de los Cuatro Vientos. Siglo XXI, Madrid.

SHIMADA Izumi, Crystal B. SCHAAF, Loonie G. THOMPSON, y Ellen MOSLEY-THOMPSON

1991 “Implicaciones culturales de una gran sequía del siglo VI D.C. en los Andes peruanos". En: Boletín de Lima 13 (77): 33-56. Lima, Editorial Los Pinos.

TELLO, Julio C.

1967 Páginas Escogidas. Selección y Prólogo de Toribio Mejía Xespe, Universidad Nacional Mayor de San Marcos, págs. 241.

TUFINIO, Moisés

2006 "Excavaciones en el frontis norte y plaza 1 de Huaca de la Luna". En: Proyecto arqueológico de Huaca de la Luna, informe técnico 2005, S. Uceda y R. Morales eds., Universidad Nacional de Trujillo, facultad de ciencias sociales, Trujillo, pp. 41-77.

UCEDA, Santiago

2008 "El templo mochica: Rituales y ceremonias." En: Los Dioses del Antiguo Perú, Crzysztof Makowski y otros. Colección arte y tesoros del Perú. Lima, Banco de Crédito del Perú.

UCEDA, Santiago y Moises TUFINIO

2003 "El Complejo Arquitectónico Religioso Moche de Huaca de la Luna: Una Aproximación a su Dinámica Ocupacional”. En: Moche: hacia el final del milenio (S. Uceda y E. Mujica, editores): 179-228, Tomo II. Actas del Segundo Coloquio sobre la Cultura Moche (Trujillo, 1 al 7 de agosto de 1999). Universidad Nacional de Trujillo y Pontificia Universidad Católica del Perú, Lima. 
UCEDA, Santiago y Ricardo MORALES

2010 Moche: Pasado y Presente. Patronato Huacas del Valle de Moche. Fondo Contravalor Perú-Francia, Universidad Nacional de Trujillo.

UBBELOHDE-DOERING, Henrich

1952 “UntersuchugenzurBaukunst der nordpeuanishen Kustentaler. Baessler-Archiv 1: 23-47. Berlín. Zurich?

1960 “Berichtuberarchaologische Feldarheiten in Perú. III. En: ETHNOS 1960: 3-4. Stockholm.

UHLE, Max

1903 “Pachacamac. Report of the William Pepper, M.D., LL.D”. Peruvian Expedition of 1896. Department of Archeology. University of Pensilvania, Philadelphia.

URTON, Gary

1982 Astronomy and Calendaries on the Coast of Perú". En: Ethnoastronomy and Archaeastronomy in the American Tropics (A. Abveny y G. Urton editores). Vol. 385:231-247, Nueva York.

VÁSQUEZ SÁNCHEZ, Segundo

1997 "Iconografía del paramento inferior de Huaca Cao Viejo, valle de Chicama, un estudio preliminar". En: Revista del Museo de Arqueología, Antropología e Historia, № 7, Universidad Nacional de Trujillo, Facultad de Ciencias Sociales, p. 157-172. Trujillo. 
